\title{
DOKTORI / PH.D. ÉRTEKEZÉS
}

Zölei-Szénási Dániel

Fizika Doktori Iskola

Szeged

2013 


\section{LÉZERES SZÓRÁSI INTERFERENCIA KONTRASZTELEMZÉSEN ALAPULÓ VÉRÁRAMLÁSMÉRŐ RENDSZER ÉPÍTÉSE}

Ph.D. értekezés

Zölei-Szénási Dániel

Témavezető:

Dr. Smausz Kolumbán Tomi Ferenc

Tudományos munkatárs

Fizika Doktori Iskola

Szegedi Tudományegyetem

Természettudományi és Informatikai Kar

Optikai és Kvantumelektronikai Tanszék

Szeged

2013 


\section{Tartalomjegyzék}

Tartalomjegyzék ......................................................................................................................... 1

1. Bevezeto ..........................................................................................................................

2. Elméleti áttekintés ...............................................................................................................5

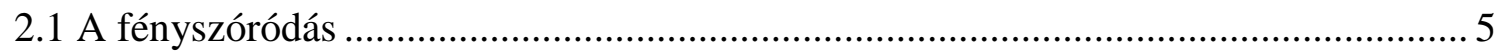

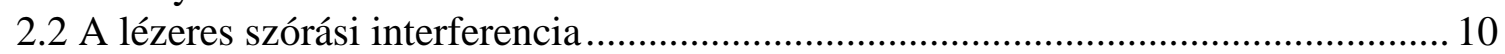

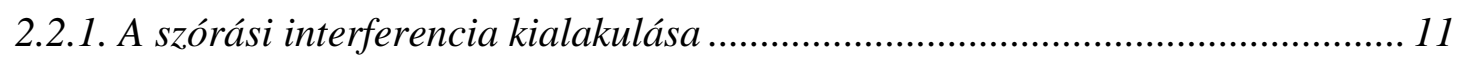

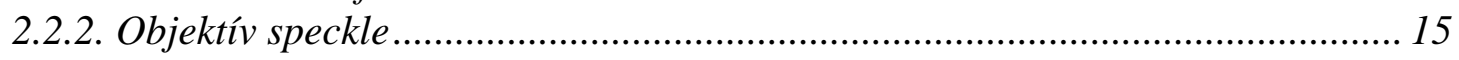

2.2.3. Szubjektív speckle ……………………………………………………..... 16

2.3. A szórási interferencia mintázat időbeli változása mozgó minta esetén: a kontrasztelemzésen alapuló véráramlás-mérés............................................................. 20

2.3.1. A szórási interferencia kontrasztelemzésen alapuló áramlásmérés alapjai...... 21

2.3.2. A kontraszt pontosabb meghatározását célzó fejlesztések................................. 25

2.3.3. A korrelációs idö pontosabb meghatározását célzó fejlesztések ........................ 28

2.4. Alternatív módszerek a perfúzió mérésére ................................................................. 33

3. Célkitüzés ...........................................................................................................................38

4. Kísérleti elrendezés...................................................................................................39

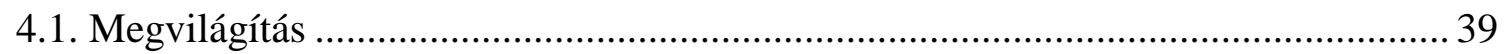

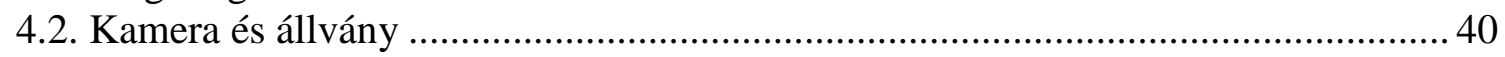

4.3. Képrögzítés és kiértékelés ................................................................................... 41

5. Szintetikus mintán elvégzett mérések. Több expozíciós idő alkalmazása.................. 43

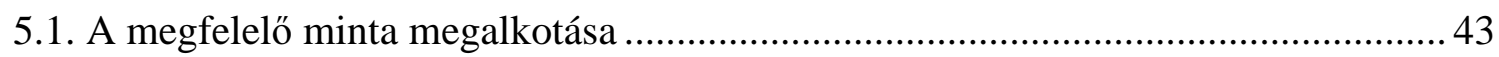

5.2. Mérések nyugvó szuszpenzión. Több expozíciós időt alkalmazó modell

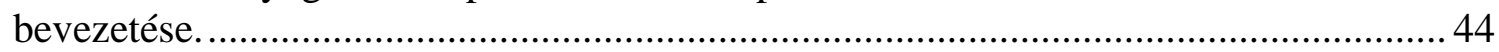

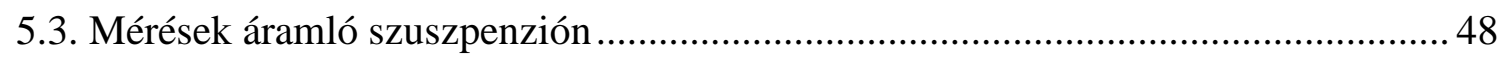

6. Mérések agyfelszínen..........................................................................................................52

6.1. Kísérleti elrendezés és mérések ……………………………………………....52

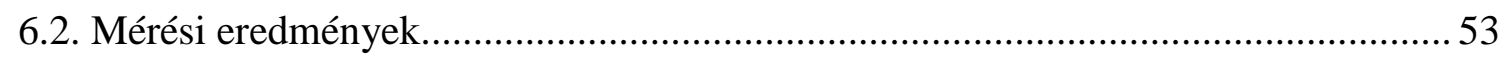

7. Bőrszövet vérellátásának vizsgálata................................................................................56

7.1. Kísérleti elrendezés és mérések …………………………………………….......56

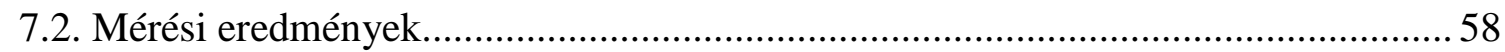

8. Az időbeli felbontás javítását célzó fejlesztések .............................................................. 63

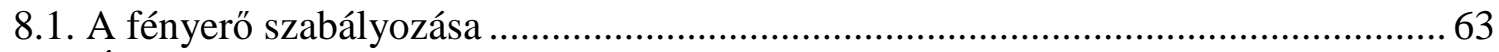

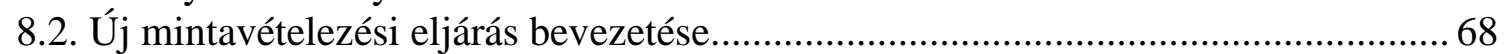

8.3. Mérések áramló szuszpenzión........................................................................... 72

8.3. Börszövet vérellátásának vizsgálata ..................................................................... 73

9. A mérésekhez és az eredmények kiértékeléséhez használt szoftver kifejlesztése .... 80

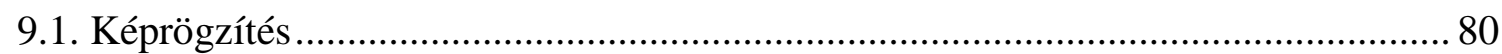

9.2. Kapcsolóüzemű fényerő- és expozíciósidő-szabályozás ............................................ 83

9.3. Közel valós idejű sebességtérkép kiszámítása és megjelenítése ................................ 85 


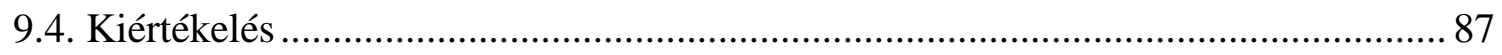

10. Összefoglalás .......................................................................................................................... 89

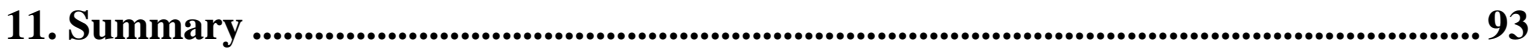

12. Köszönetnyilvánítás............................................................................................................99

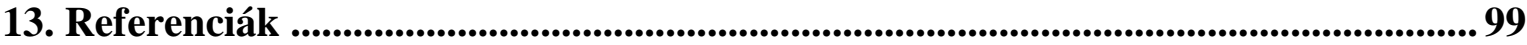




\section{Bevezető}

Ha egy koherens fénnyel megvilágított optikailag egyenetlen felületre tekintünk, akkor egy szemcsés szerkezetű interferenciaképet látunk. Ez a jelenség a szórási interferencia, melyet napjainkban számos területen alkalmaznak: találkozhatunk vele ipari és orvosi berendezésekben, mérőmüszerekben, de olyan hétköznapi eszközökben is felhasználják, mint amilyen a lézeres optikai egér.

Az orvostudományban a jelenség egyik alkalmazási területe a szórási interferencia kontrasztelemzésen alapuló véráramlásmérés, melynek során a vizsgált agyfelszíni vagy szemfenéki szövetet lézerfénnyel világítják meg. Mivel ekkor a fény főként a vörösvértestekről szóródik, a területet figyelő kamera fényérzékeny chipjén keletkező interferenciakép azok mozgása miatt időben változik. Ez a fluktuáció az adott expozíciós idővel készült felvételeken az interferenciakép elmosódását (a kontraszt csökkenését) okozza, melyből következtetni lehet a véráramlás intenzitására. A képkiértékelési eljárások eleinte inkább csak kvalitatívan jellemezték a véráramlásban, perfúzióban bekövetkező esetleges változásokat. Börszövet esetén ez különösen igaz volt, mivel a mozdulatlan szövetrészek okozta statikus szóródás jelentősen torzította a mérési eredményeket. Habár a témában Fercher és Briers 1981-es úttörő munkáját követően számos publikáció született, több mint húsz évnek kellett eltelnie ahhoz, hogy mérési pontosság növelését célzó kutatások elkezdődjenek. Mára a mérési eredmények reprodukálhatósága jelentősen javult, mégsem sikerült teljes mértékben kiküszöbölni a statikus szóródás torzító hatását. Emiatt a jelenleg alkalmazott, egyetlen expozíciós időt felhasználó módszerek nem teszik lehetővé a különböző személyeken, vagy egy személyen, de különböző körülmények között elvégzett mérések eredményeinek összehasonlítását.

A lézeres szórási interferencia kontrasztelemzésen alapuló véráramlás-mérés ígéretes témájára az SZTE Élettani Intézet munkatársai hívták fel figyelmünket. Laboratóriumunkban 2008-ban kezdődött meg a kutatás, és még ebben az évben csatlakoztam a kutatáshoz. 2009 januárjában meg is jelent első közleményünk, melyben bemutattuk, hogy több expozíciós idő és egy egyszerü modell alkalmazásával a nem mozgó elemek által okozott torzulás kiküszöbölhető. Érdekes módon más kutatócsoportok is ugyanebben az időszakban kezdtek el érdeklődni a téma iránt, így 2008 nyara és 2009 nyara között több publikáció is napvilágot látott a problémakörrel kapcsolatosan. 
Dolgozatom témája egy olyan szórási interferencia kontrasztelemzésen alapuló mérőrendszer fejlesztése, mely több nagyságrendet átfogó expozíciós idő tartományon készült felvételek kiértékelésével lehetővé teszi a mérési pontosság jelentős növelését. Mivel az általam épített eszköz közel valós idejű mérésekre is képes, ígéretes alternatívája lehet a meglehetősen költséges és lassú pásztázó Doppleres véráramlásmérő eszközöknek.

Dolgozatom első részében a fényszóródás, a lézeres szórási interferencia és az ahhoz kapcsolódó kontrasztelemzés alapján történő sebességmérés megértéséhez szükséges elméleti áttekintés található.

Ezt követően bemutatom a kutatás során elért eredményeket, az általam kidolgozott és alkalmazott mérési módszerek fejlődését. Megmutatom, miért előnyös több expozíciós idő alkalmazása szintetikus minta esetén, illetve agyfelszín és börszövet vérellátásának vizsgálata során.

Végül bevezetek egy olyan mérési protokollt, melynek segítségével jelentős mértékben javítható az általam alkalmazott módszer időbeli felbontása, elérhetővé téve a közel valós idejű méréseket. 


\section{Elméleti áttekintés}

\subsection{A fényszóródás}

Fényszóródásról akkor beszélünk, ha a fényt egy közegben található szemcse véletlenszerüen eltéríti eredeti haladási irányától. Ennek köszönhető, hogy kék az ég, vagy, hogy fehérek a felhők. A körülöttünk lévő dolgok jellemzően a felületükön létrejövő fény szóródásának köszönhetően láthatóak. A fényszóródás két speciális esete a Rayleigh- féle és a Mie-féle fényszóródás. Az előbbi akkor lép fel, amikor a fényszóródást okozó szemcsék átmérője jóval kisebb a szóródó fény hullámhosszánál. Ebben az esetben a szórási hatáskeresztmetszet arányos a hullámhossz negyedik hatványának reciprokjával, ennek köszönhető az ég kék, vagy a lenyugvó nap vörös színe. Az utóbbi jelenség akkor lép fel, ha a szemcsék átmérője lényegesen nagyobb a fény hullámhosszánál. Ebben az esetben az egyes fotonok haladási iránya a szóródás során csak kismértékben változik meg. A felhők és a füst fehér színe a Mie-féle szóródásnak köszönhető. A fényszóródás ezen fajtája dominál akkor is, amikor látható vagy közeli infravörös fény szóródik a vörösvértesteken.

A dolgozatban a fényszóródás leírása során a következő jelöléseket használom:

- vektor: $\vec{A}$

- vektor nagysága: $A$

- egységvektor: $\hat{a}$

- komplex konjugált: $\vec{A}^{*}$

- időátlag / időbeli várható érték: \langle\rangle$_{t}$

- laterális átlag / várható érték: 〈 $\rangle$

Képzeljünk el egy $\varepsilon_{0}$ permittivitású és $\mu_{0}$ permeabilitású közegben haladó $\lambda$ hullámhosszú elektromágneses síkhullámot. Ez a tér valamely $\vec{r}$ pontjában az

$$
\vec{E}_{b}(\vec{r})=\hat{p} E_{b} \exp (i k \hat{b} \cdot \vec{r})
$$


összefüggéssel írható le, ahol $\hat{p}$ a hullám polarizációs iránya, $E_{b}$ az amplitúdója, $k=2 \pi / \lambda$ a hullámszáma, $\hat{b}$ pedig a haladási irányába mutató egységvektor. Az egyszerübb tárgyalhatóság kedvéért legyen $\left|E_{b}\right|$ egységnyi, így (1) a következő alakot ölti:

$$
\vec{E}_{b}(\vec{r})=\hat{p} \exp (i k \hat{b} \cdot \vec{r}) .
$$

Tegyük fel továbbá, hogy sem a közeg, sem pedig a benne lévő szóró szemcsék anyaga nem mágnesezhető. Ekkor a beérkező elektromágneses síkhullám szóródásához szükséges, hogy a szóró szemcse a közegtől eltérő dielektromos állandóval rendelkezzen:

$$
\varepsilon_{r}(\vec{r})=\frac{\varepsilon(\vec{r})}{\varepsilon_{0}},
$$

ahol $\varepsilon(\vec{r})$ helyfüggő komplex mennyiség, segítségével leírhatóak a szemcsében fellépő esetleges veszteségek és inhomogenitások. Az 1. ábra a beérkező síkhullámot és a szórt hullámot mutatja valamely $\hat{s}$ irány mentén:

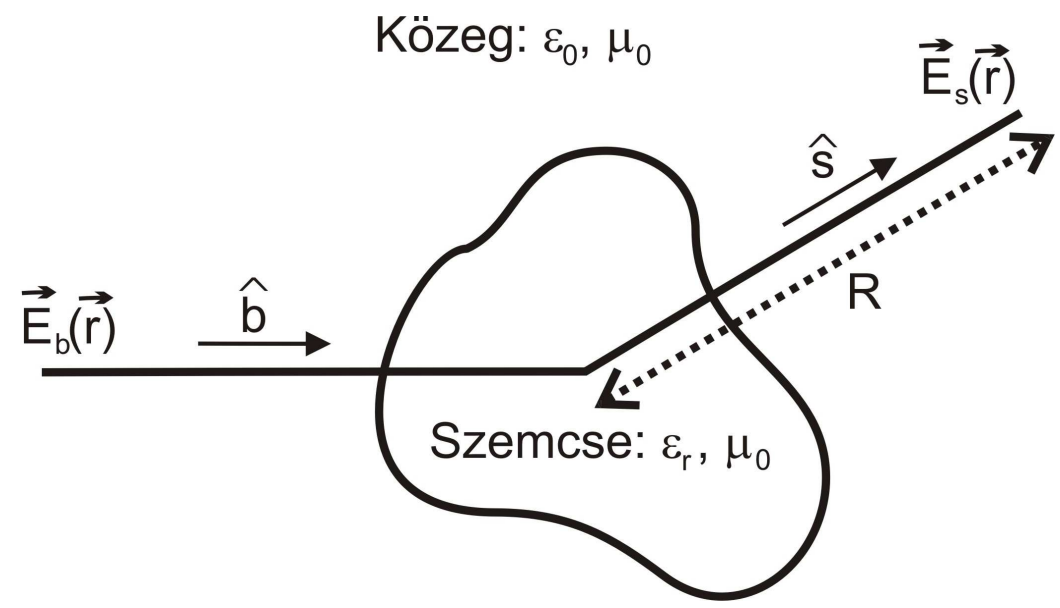

1. ábra. A beérkező síkhullám és a szemcsén szórt hullám valamely î irány mentén, a szemcsétöl R távolságra

A térerősség a szemcsétől $R$ távolságra, valamely $\hat{s}$ irány mentén a beérkező $\vec{E}_{b}$ síkhullám és a szórt $\vec{E}_{s}$ hullám szuperpozíciója. Ez utóbbi leírása egy átlagosan $D$ átmérőjű szemcse esetén igen bonyolult a szemcsétől $R<D^{2} / \lambda$ távolságra, mivel a szemcse különböző 
részeiből kiinduló elemi hullámok interferenciája összetett amplitúdó- és fázisviszonyokat hoz létre. A szemcsétől $R>D^{2} / \lambda$ távolságra azonban $\vec{E}_{s}$ gömbhullámként írható le az

$$
\vec{E}_{s}(\vec{r})=\vec{f}(\hat{s}, \hat{b}) \cdot \frac{\exp (i k R)}{R},
$$

ahol $\vec{f}(\hat{s}, \hat{b})$ a szórási amplitúdó: leírja a szórt hullám amplitúdóját, fázisát és polarizációját a szemcsétől $\hat{s}$ irányban és távol, ha a szemcsét egy $\hat{b}$ irányú, egységnyi amplitúdójú elektromágneses hullám „világítja meg”. A beérkező síkhullám és a szórt hullám Poynting-vektorai (teljesítményfluxusai)

$$
\begin{gathered}
\vec{S}_{b}=\frac{\vec{E}_{b} \times \vec{H}_{b}}{2}=\frac{\left|E_{b}\right|^{2}}{2 \mu_{0} c} \hat{b}, \\
\vec{S}_{s}=\frac{\vec{E}_{s} \times \vec{H}_{s}}{2}=\frac{\left|E_{s}\right|^{2}}{2 \mu_{0} c} \hat{s},
\end{gathered}
$$

ahol $\vec{H}_{b}$ és $\vec{H}_{s}$ a beérkező síkhullám és a szórt hullám mágneses térerőssége. A Poyntiong-vektorok segítségével felírható a differenciális szórási hatáskeresztmetszet:

$$
\sigma_{d}(\hat{s}, \hat{b})=\lim _{R \rightarrow \infty} \frac{R^{2} S_{s}}{S_{b}}=|f(\hat{s}, \hat{b})|^{2}
$$

Ha a differenciális szórási hatáskeresztmetszetet az $\omega$ differenciális térszög szerint a szemcse körül a teljes térszögre integráljuk, megkapjuk a szórási keresztmetszetet:

$$
\sigma_{s}=\int_{0}^{4 \pi} \sigma_{d} d \omega
$$

A szemcse jellemzően nemcsak szórja a rá eső sugárzást, hanem el is nyeli annak egy részét. Ez jellemezhető a $\sigma_{a}$ abszorpciós hatáskeresztmetszettel. $\sigma_{\mathrm{s}}$ és $\sigma_{\mathrm{a}}$ segítségével megadható a $\sigma_{t}$ teljes hatáskeresztmetszet: 


$$
\sigma_{t}=\sigma_{a}+\sigma_{s}
$$

$\sigma_{\mathrm{t}}$ segítségével is felírható a differenciális szórási keresztmetszet:

$$
\sigma_{d}(\hat{s}, \hat{b})=\frac{\sigma_{t}}{4 \pi} p(\hat{s}, \hat{b})
$$

ahol $p(\hat{s}, \hat{b})$ a fázisfüggvény, ami a szórt sugárzás szög szerinti eloszlását írja le. Ahogy a fenti leírásból kitűnik, a szemcséken végbemenő fényszóródás leírásának kulcseleme az $\vec{f}(\hat{s}, \hat{b})$ szórási amplitúdó megtalálása, mivel ennek segítségével számítható ki a térerősség amplitúdója, fázisa és iránya a tér bármely pontjában az

$$
\vec{E}(\vec{r})=\vec{E}_{b}(\vec{r})+\vec{E}_{s}(\vec{r})
$$

összefüggés alapján. Gömb, ellipszoid vagy korong alakú szemcsék esetén az $\vec{f}(\hat{s}, \hat{b})$ analitikusan is megadható, azonban ennek részletes leírása meghaladja a dolgozat témáját. Az Olvasó a terület részletes kifejtését Akira Ishimaru könyvében [1] találhatja meg.

A vörösvértestek alakja jelentősen eltér a fentebb említett, egyszerübb a geometriai alakzatoktól (2. ábra), így számos tanulmány tárgyát képezte már a fény szóródásának leírása vörösvértestek esetén [2]-[5].

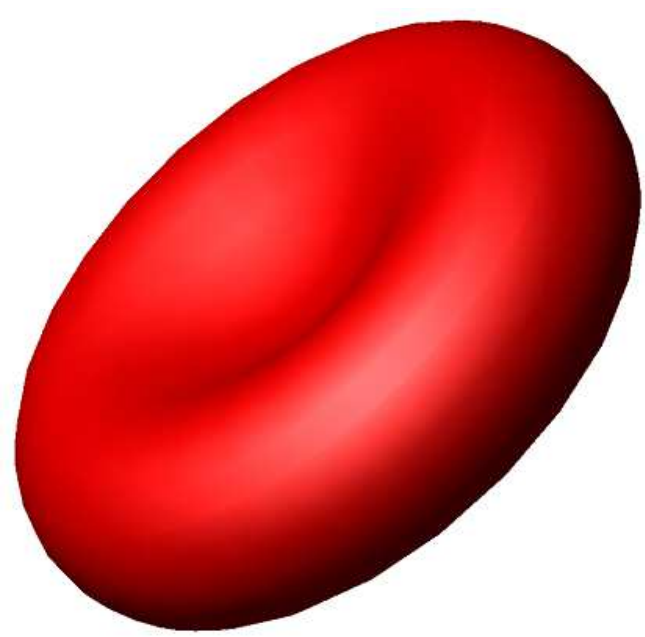

2. ábra. A vörösvértest alakja [3] 
Ezen munkák szerzői különféle számítógépes szimulációk segítségével írták le a fény szóródását. Bár e modellek rendkívül hasznosak, az egészséges vörösvértestek - a vér áramlásának megkönnyítése érdekében - mindig felveszik a vér áramlásprofilját (3. ábra), így a fényszóródás egzakt leírása valójában még bonyolultabb [6].

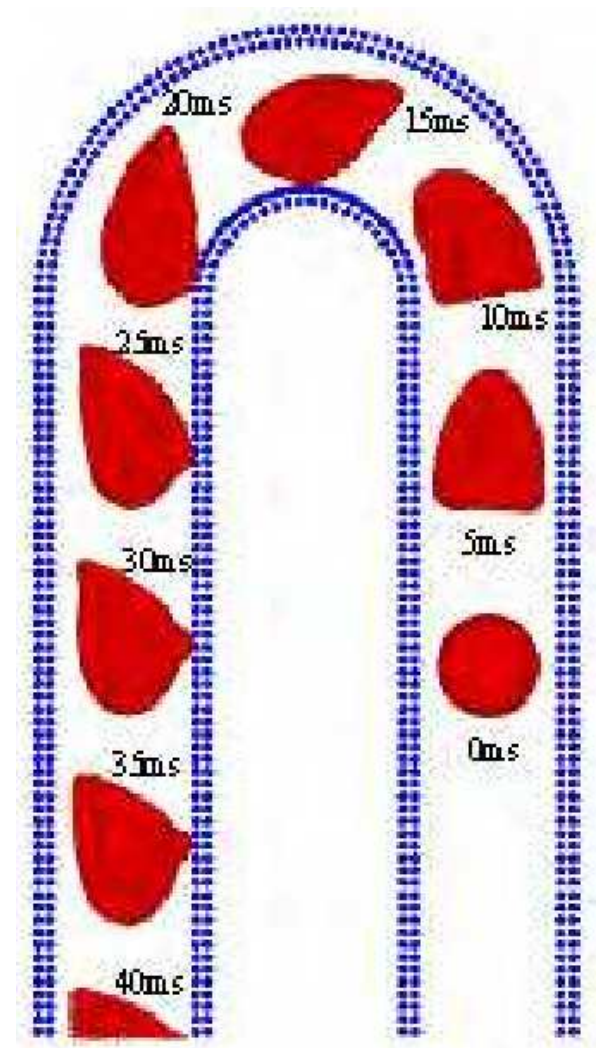

3. ábra. Egy vörösvértest alakváltozása az áramlási során. Kezdetben (0 ms) állt a vörösvértest, majd az áramlás megindulásával folyamatosan alkalmazkodott az áramlásprofilhoz [6].

A fény vörösvértesteken történő szóródásának leírását tovább nehezíti, hogy - bár a vérplazma törésmutatója állandónak $(1,34)$ tekinthető [7], - a vörösvértestek törésmutatója nem állandó, hanem helyfüggő a vörösvértesten belül (átlagosan 1,39), és további függést mutat a hemoglobin oxigenizáltságától [7], [8]. Mivel a diszkrét vörösvértesteken való fényszóródás leírása a sejtek számának növekedésével egyre bonyolultabbá válik, praktikusabb a fényszóródást makroszkopikus szempontból vizsgálni. A sugárzás extinkciója valamely elnyelő és szóró közegben szorosan összefügg a teljes hatáskeresztmetszettel: 


$$
I(l)=I_{0} \exp (-\beta l)=I_{0} \exp \left(-N \sigma_{t} l\right)
$$

ahol $\beta$ az extinkciós együttható, $I(l)$ az eredetileg $I_{0}$ intenzitású sugárzás erőssége $l$ mélységben, $N$ pedig a szemcsék térfogati sűrüsége. Mivel az $\vec{f}(\hat{s}, \hat{b})$ szórási amplitúdó a hullámszámmal, vagy a hullámszám valamely hatványával arányos [1], a szórási keresztmetszet növekszik a hullámhossz csökkenésével. Ennek megfelelően az

$$
L=\frac{1}{\beta}=\frac{1}{N \sigma_{t}}
$$

behatolási annál nagyobb, minél nagyobb a megvilágító fény hullámhossza [9]. Barun és munkatársai megmutatták, hogy míg $650 \mathrm{~nm}$-en $4 \mathrm{~mm}$ alatti, addig $800 \mathrm{~nm}$-en $6 \mathrm{~mm}$ feletti a fény behatolási mélysége bőr esetén [10]. Éppen ezért egy, a bőr vérellátását vizsgáló mérörendszer esetén érdemes nagyobb hullámhosszú, azaz közeli infravörös fényt használni, mivel a látható fényhez képest az infravörös nagyobb hányada jut el a néhány mm mélyen lévő vörösvértestekhez, így nagyobb pontossággal határozhatóak meg a perfúzió intenzitásában bekövetkező változások.

\subsection{A lézeres szórási interferencia}

Ha egy optikailag egyenetlen felültre koherens fény esik, az arról visszaszóródó fényt egy ernyővel vagy kamerával felfogva jellegzetes, szemcsés képet kapunk. Ezt a jelenséget szórási interferenciának nevezzük, a szakirodalomban az angol „speckle” néven találhatjuk meg. A jelenség nemcsak fény, hanem ultrahang vagy rádióhullámok használata esetén is tapasztalható. Mivel a szemcsék elrendeződése teljesen véletlenszerü, a jelenség a legtöbb alkalmazás szempontjából károsnak tekinthető, hiszen rontja a jelminőséget, zajt visz a különböző rendszerekbe, így a '70-es évekig főként a kiküszöbölésére koncentráltak. Csak ezután jelentek meg olyan alkalmazások, amelyek éppen magát a szórási interferenciát használták fel [11]. Manapság számtalan területen alkalmazzák a jelenséget, többek közt sebesség- [12]-[14] és távolságmérésre [14], [15], felületelemzésre [16], [17], véletlenszám-generálásra [18], [19] stb. Ma már bármelyik szaküzletben vásárolhatunk lézeres optikai egeret, amely (a LED- es megvilágítást alkalmazó típusoktól eltérően) nem közvetlenül a felület elmozdulását figyeli, hanem a lézerfény által létrehozott szórási 
interferenciakép változásaira reagál, így akár a fény hullámhosszával összemérhető elmozdulást is képes érzékelni.

A 4. ábrán egy latex mikrogömb szuszpenzióról 2 ms-os expozíciós idővel készült szórási interferenciakép látható.

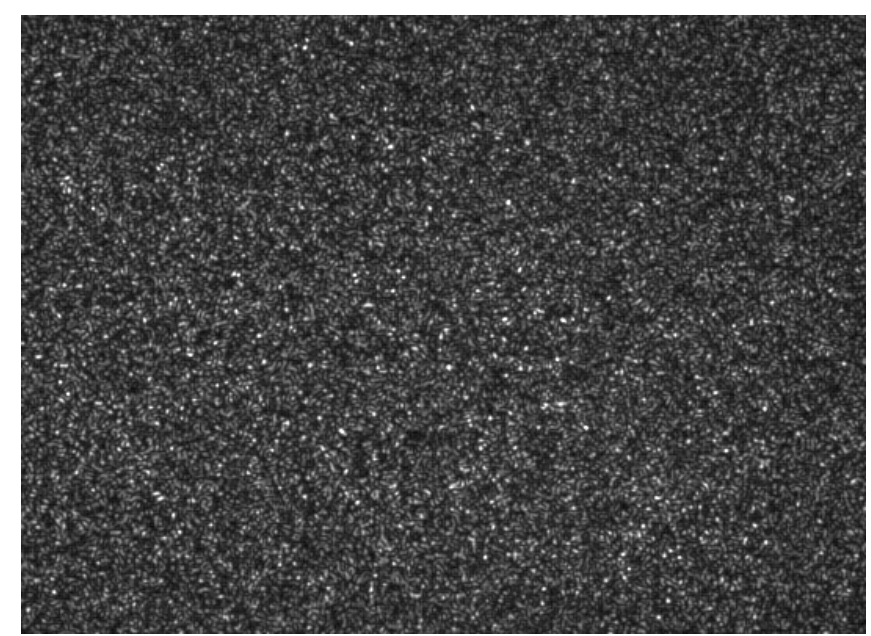

4. ábra. Latex mikrogömb szuszpenzióról 2 ms-os expozíciós idővel készült szórási interferenciakép

\subsubsection{A szórási interferencia kialakulása}

Ha koherens fény egy olyan felülethez ér, amelyen a struktúrák mérete meghaladja a fény hullámhosszát, akkor azon többszörösen szóródik. A felületről, mint szóró centrumok összességéből induló szórt fény egy, a felülettől távol elhelyezett ernyőn jellegzetes, foltos mintázatot hoz létre. Akkor is hasonlót tapasztalhatunk, ha a fény nem egy érdes felületre, hanem különálló szemcsék sokaságára esik (pl. 4. ábra). Mindkét esetre egy-egy lehetséges sugármenetet mutat be az 5. ábra. 

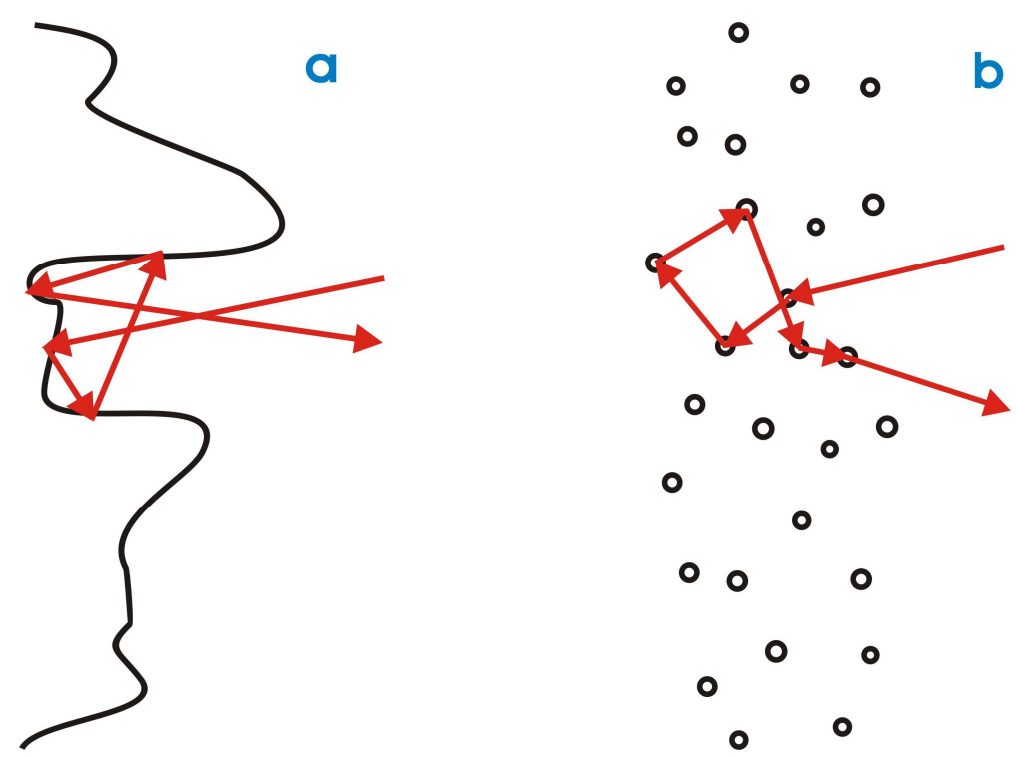

5. ábra. Fény szóródásának demonstrálása érdes felületen (a) és apró szemcséken (b).

A jelenség leírható úgy is, ha tekintünk egy elektromágneses síkhullámot, ami a felületen vagy a szemcséken, mint szóró centrumokon szóródik, majd az ernyőn a szórt elemi hullámok szuperpozíciója alakítja ki a szórási interferencia mintázatot. Az ernyő bármely pontján a kialakult térerősség értéke

$$
\begin{gathered}
E=\frac{1}{\sqrt{N}} \sum_{n=1}^{N} e_{n} * \exp \left(i * \varphi_{n}\right), \\
E_{\mathrm{Re}}=\operatorname{Re}(E)=\frac{1}{\sqrt{N}} \sum_{n=1}^{N} e_{n} * \cos \varphi_{n}, \\
E_{\mathrm{Im}}=\operatorname{Im}(E)=\frac{1}{\sqrt{N}} \sum_{n=1}^{N} e_{n} * \sin \varphi_{n},
\end{gathered}
$$

ahol $\phi_{n}$ az n-edik komponens fázisát, $N$ pedig az elemi hullámok számát jelöli. Ha feltételezzüik, hogy a szóró centrumokból induló elemi hullámok $\sqrt{N}^{-1} e_{n}$ amplitúdói és $\phi_{n}$ fázisai véletlenszerüek és függetlenek egymástól, $\phi_{n}$ értéke 0 és $2 \pi$ között változik, valamint $N$ kellően nagy szám, akkor teljesül, hogy az ernyő valamely pontjában

$$
\begin{aligned}
& \left\langle E_{\mathrm{Re}}\right\rangle_{t}=0, \\
& \left\langle E_{\mathrm{Im}}\right\rangle_{t}=0,
\end{aligned}
$$




$$
\begin{aligned}
& \sigma_{t, \mathrm{Re}}{ }^{2}=\left\langle E_{\mathrm{Re}}{ }^{2}\right\rangle_{t}=\frac{1}{N} \sum_{m=0}^{N} \sum_{n=0}^{N} e_{m} * e_{n} * \cos \varphi_{m} * \cos \varphi_{n},
\end{aligned}
$$

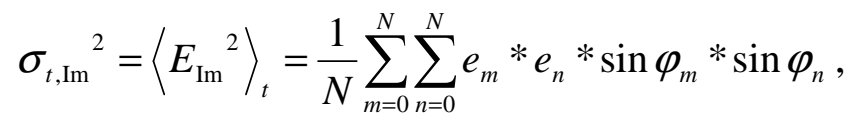

ahol \langle\rangle$_{t}$ a várható értéket, $\sigma_{t}^{2}$ az intenzitás szórásnégyzetét, $N$ pedig az elemi hullámok számát jelöli. A $t$ index az időbeli statisztikai jellemzésére utal. A későbbiek során a $t$ index hiánya a laterális statisztikai jellemzésre utal. Mivel a (19) és (20) és egyenlet csak $m$ $=n$ esetben ad 0 -tól különböző eredményt, így ezek a következő alakra egyszerűsödnek:

$$
{\sigma_{t, E}^{2}}^{2}=\sigma_{t, \operatorname{Re}}^{2}=\sigma_{t, \operatorname{Im}}^{2}=\frac{1}{N} \sum_{n=0}^{N} \frac{\left\langle e_{n}^{2}\right\rangle_{t}}{2}
$$

ahol $\sigma_{t, E}^{2}$ a térerősség időbeli varianciáját jelöli. A centrális határeloszlás tétel alapján a térerősség valós és képzetes részének eloszlása normális:

$$
P_{\mathrm{Re}, \mathrm{Im}}\left(E_{\mathrm{Re}}, E_{\mathrm{Im}}\right)=\frac{1}{2 \pi{\sigma_{t, E}}^{2}} \exp \left(-\frac{E_{\mathrm{Re}}{ }^{2}+E_{\mathrm{Im}}{ }^{2}}{{\sigma_{t, E}}^{2}}\right) .
$$

A valós mérések során jellemzően az amplitúdó és a fázis nem, csak az intenzitás mérhető közvetlenül, így érdemes figyelmünket erre összpontosítani. A sugárzás amplitúdója, intenzitása és fázisa a tér valamely pontjában

$$
\begin{gathered}
E=\sqrt{{E_{\mathrm{Re}}}^{2}+E_{\mathrm{Im}}{ }^{2}}, \\
I=E^{2}={E_{\mathrm{Re}}}^{2}+E_{\mathrm{Im}}{ }^{2}, \\
\varphi=\arctan \left(\frac{E_{\mathrm{Im}}}{E_{\mathrm{Re}}}\right) .
\end{gathered}
$$

Ekkor a szükséges transzformáció Jacobi-mátrixa 


$$
J=\left[\begin{array}{ll}
\frac{\partial E_{\mathrm{Re}}}{\partial I} & \frac{\partial E_{\mathrm{Re}}}{\partial \varphi} \\
\frac{\partial E_{\mathrm{Im}}}{\partial I} & \frac{\partial E_{\mathrm{Im}}}{\partial \varphi}
\end{array}\right],
$$

melynek segítségével megkapjuk a

$$
P_{I, \varphi}(I, \varphi)=P_{\mathrm{Re}, \mathrm{Im}}(E \cdot \cos \varphi, E \cdot \sin \varphi) \cdot\|J\|
$$

együttes eloszlást (ahol || $\mid$ a mátrix determinánsát jelöli). Ez alapján az intenzitás eloszlása és várható értéke

$$
\begin{gathered}
P(I)=\int_{-\pi}^{\pi} P_{I, \varphi}(I, \varphi) \cdot d \varphi=\frac{1}{2 \sigma_{t, E}^{2}} \exp \left(-\frac{I}{2 \sigma_{t, E}^{2}}\right), \\
\langle I\rangle_{t}=\int_{0}^{\infty} I \cdot P(I) \cdot d I=2{\sigma_{t, E}}^{2} .
\end{gathered}
$$

A (29) egyenlettel egyszerüsíthető a (28):

$$
P(I)=\frac{1}{\langle I\rangle_{t}} \exp \left(-\frac{I}{\langle I\rangle_{t}}\right) .
$$

Azt a szórási interferencia mintázatot, ami ezen tulajdonságokkal rendelkezik, ideális szórási interferencia nevezzük mintázatnak (az angol nyelvű szakirodalomban fully developed speckle néven található meg). Az intenzitás varianciájára a következő jellemző:

$$
\sigma_{t}^{2}=\int_{0}^{\infty}\left(I-\langle I\rangle_{t}\right)^{2} P(I) \cdot d I=\langle I\rangle_{t}^{2}
$$

A speckle mintázat egyik fontos mérőszáma a kontraszt, melynek definíciója 


$$
K=\frac{\sigma}{\langle I\rangle}
$$

A fejezet későbbi részében kiderül majd, hogy ennek értékéből a lézeres szórási interferencia kontrasztelemzés során következtethetünk a vér (vagy bármely, szemcséket tartalmazó áramló közeg) áramlási sebessége. Ideális speckle mintázat esetén a kontraszt értéke 1. A nem polarizált fény által létrehozott mintázat két (egymásra merőleges polarizációs síkkal rendelkező) polarizált mintázat szuperpozíciójának tekinthető, így a kontraszt értéke [20]

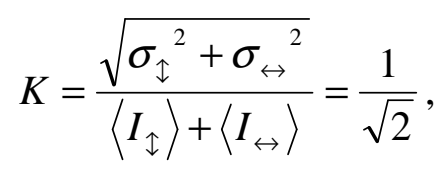

ahol $\uparrow$ és $\leftrightarrow$ a két, egymásra merőleges polarizációs síkra utal.

\subsubsection{Objektív speckle}

A megvilágított felület minden egyes pontja elemi hullámforrásként viselkedik. Ha a megvilágított felülettel szemben egy ernyőt helyezünk el, akkor azon a szórási interferencia mintázatot az elemi forrásokból induló véletlenszerü gömbhullámok szuperpozíciója alakítja ki (6. ábra).

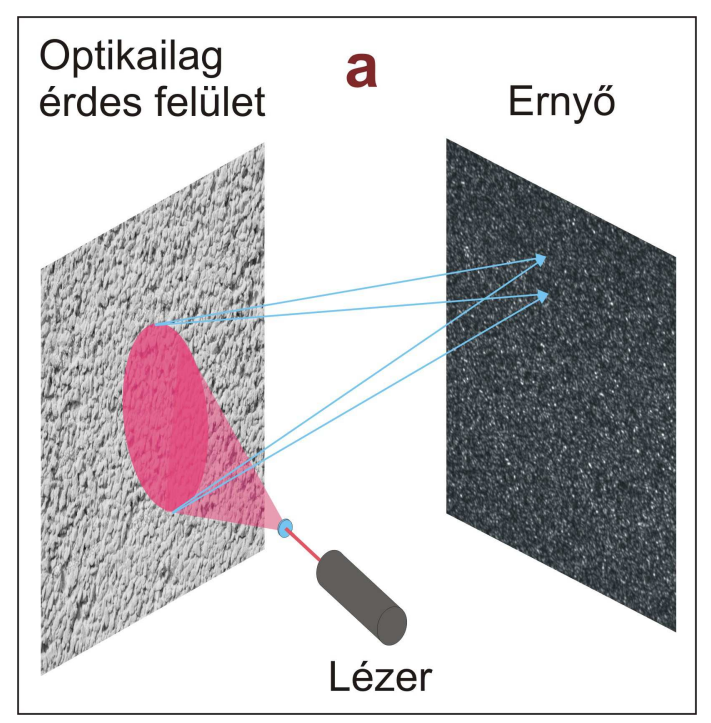

6. ábra. Objektív specke 
A foltok átmérőjét a térbeli intenzitás eloszlás autokorrelációjának segítségével határozhatjuk meg:

$$
R_{I}\left(\left(x_{1}, y_{1}\right) ;\left(x_{2}, y_{2}\right)\right)=\left\langle I\left(x_{1}, y_{1}\right) \cdot I\left(x_{2}, y_{2}\right)\right\rangle \text {. }
$$

A számolás a Huygens-Freesnel-elv és a Fresnel-féle közelítés alkalmazásával végezhető el, azonban a részletes levezetés meghaladja a dolgozat kereteit. Ha a megvilágított felület egy $D$ oldalhosszúságú négyzet, akkor

$$
R_{I}\left(\left(x_{1}, y_{1}\right) ;\left(x_{2}, y_{2}\right)\right)=\langle I\rangle^{2}\left[1+\operatorname{sinc}^{2} \frac{D\left(x_{2}-x_{1}\right)}{\lambda \mathrm{z}} \operatorname{sinc}^{2} \frac{D\left(y_{2}-y_{1}\right)}{\lambda \mathrm{z}}\right]
$$

ahol $\lambda$ a fény hullámhossza, $z$ pedig a felület és az ernyő távolsága, és

$$
\operatorname{sinc}(k)=\frac{\sin (\pi k)}{\pi k}
$$

A foltok $d$ átmérője az az $x_{2}-x_{1}$ vagy $y_{2}-y_{1}$ távolság, amelynél a sinc ${ }^{2}$ függvény értéke először 0 lesz [21], azaz

$$
d=\frac{\lambda z}{D}
$$

Érdemes megfigyelni, hogy a (36) összefüggés alakja megegyezik egy homogén síkhullámmal kivilágított négyzet elhajlási képével. Mivel esetünkben a D oldalhosszúságú négyzet véletlenszerü fázissal és véletlenszerü irány szerinti amplitúdóval rendelkező gömbhullámok forrásaiból áll, így az ernyőn keletkező intenzitás eloszlás is számos, a (36) és (37) formula segítségével leírható véletlenszerü foltokból áll.

\subsubsection{Szubjektív speckle}


Abban az esetben, amikor a kép nem ernyőn, hanem egy optikai leképező rendszer filmjén, fotólemezén vagy chipjén keletkezik, az objektív speckle-höz hasonló mintázat jön létre, azonban a szemcsék méretét a fényelhajlás miatt az optikai elemek is befolyásolják (7. ábra), innen ered a szubjektív speckle elnevezése.

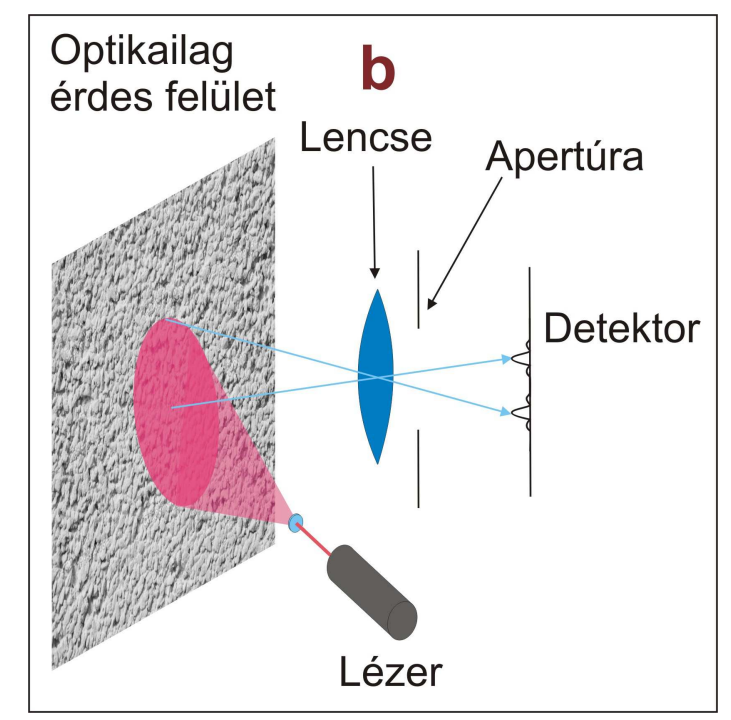

7. ábra. Szubjektív speckle.

$\mathrm{Az}$ egyszerübb tárgyalhatóság kedvéért tekintsük a leképező lencsét ideális, vékony lencsének, az apertúrát pedig kör alakúnak. A tárgysík minden egyes pontjának megfelel egy pont a képsíkon. Mivel az apertúra átmérője véges, így a tárgysík minden pontjának egy-egy elhajlási kép felel meg a képsíkon. Tekintsük az apertúrát egy $R$ sugarú, kör alakú résnek, amelyre a kör síkjára merőleges irányból esik egy elektromágneses síkhullám. A résen való elhajlást a 8 . ábra szemlélteti. A rés mögött a térerősség szög szerinti eloszlása a rés Fourier-transzformáltjaként írható le:

$$
E=2 C \exp \left(i k r_{0}\right) \int_{-R}^{R} \exp (i k x \sin \theta) \sqrt{R^{2}-x^{2}} d x
$$

ahol $C$ a dimenziókat és skálafaktorokat tartalmazza, $k$ a síkhullám hullámszáma, $\int_{-R}^{R} \sqrt{R^{2}-x^{2}} d x$ pedig a kör területe. Az $u=x / R$ és $\rho=k R \sin \theta$ helyettesítésekkel a térerősség az 


$$
E=2 C \exp \left(i k r_{0}\right) R^{2} \int_{-1}^{1} \exp (i \rho u) \sqrt{1-u^{2}} d u
$$

összefüggéssel írható le.

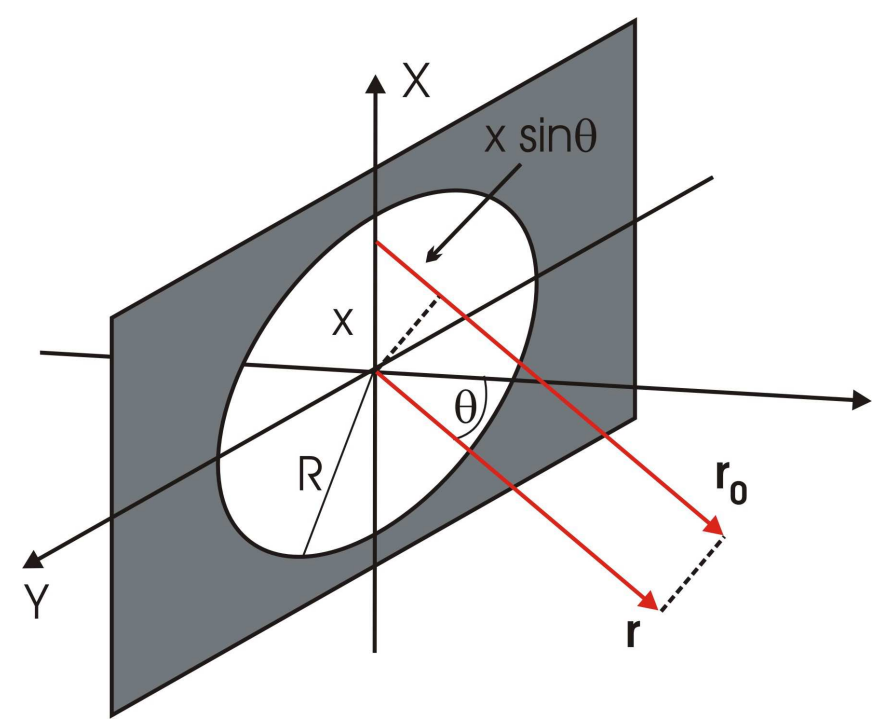

8. ábra. Fényelhajlás $R$ sugarú kör alakú résen. Az ábra két $\theta$ szögben elhajló fénysugarat mutat be.

Kihasználva azt, hogy a szinusz páratlan, míg a koszinusz páros függvény,

$$
E=2 C \exp \left(i k r_{0}\right) R^{2} 2 \int_{0}^{1} \cos (\rho u) \sqrt{1-u^{2}} d u
$$

adódik. Érdemes észrevenni, hogy a fenti összefüggés egy része hasonlóságot mutat a $J_{1}$ elsőrendű Bessel-függvénnyel:

$$
J_{1}(\rho)=\frac{2 \rho}{\pi} \int_{0}^{1} \cos (\rho u) \sqrt{1-u^{2}} d u .
$$

Ha a síkhullám eredeti intenzitását $I_{0}=\left\lfloor C \exp \left(i k r_{0}\right) R^{2} \pi\right\rfloor$ módon definiáljuk, akkor adott $\theta$ szög mentén az intenzitás nagysága az 


$$
\frac{I(\rho)}{I_{0}}=\left(\frac{2 J_{1}(\rho)}{\rho}\right)^{2}
$$

összefüggéssel írható le. A 9. ábra egy ilyen folt keresztmetszetét mutatja.

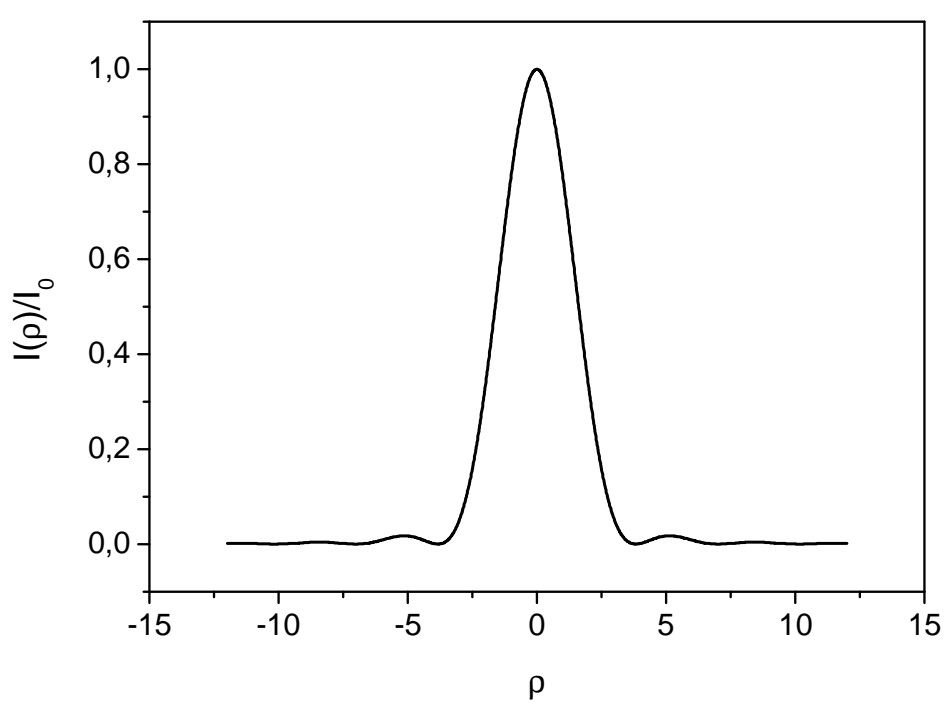

9. ábra. Egy Airy-korong keresztmetszete.

Tekintsük a folt első és további maximumait elhanyagolhatónak. Így két pont képe akkor nem befolyásolja egymást, ha minimumaik egymásra esnek, vagy ennél távolabb vannak egymástól. Mivel az elsőrendű Bessel-függvény első minimuma körülbelül 3,83-nál található, így a folt szögátméröje

$$
\sin \theta=\frac{3,83 \lambda}{2 \pi R}=\frac{1,22 \lambda}{a}
$$

ahol $a$ az apertúra átmérője. Ha az apertúra a képsíktól $l$ távolságra helyezkedik el, akkor a keletkező Airy-korong átmérője

$$
D=2 l \sin \theta=\frac{2,44 \lambda}{a}
$$


Bár a folyamat pontos leírásához sok, az eddigiekben elhanyagolt tényezőt (a fényelhajlás Fresnel-féle közelítése, a fény nem merőleges beesése az apertúrán, a lencse véges vastagsága, stb.) is figyelembe kellene venni, azonban ez meghaladja a dolgozat témáját. Mindemellett az itt közölt leírás elegendő lehet a problémakör megértéséhez.

Mivel a tárgysík minden egyes pontjának képe ilyen módon képeződik le, a képsíkban létrejövő kép a keletkező foltok amplitúdó- és fázishelyes összege. A 10. ábrán két folt keresztmetszeti képe látható, ha részben átfedik egymást vagy éppen teljesen függetlenek egymástól.
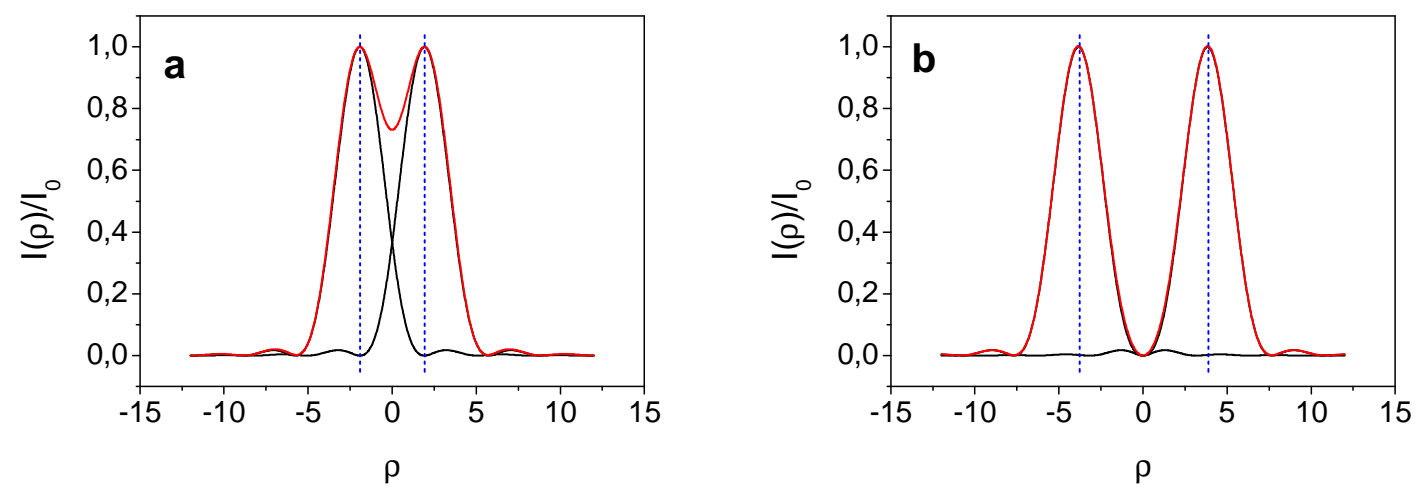

10. ábra. Két Airy-korongként leképezödö folt keresztmetszeti képe, ha részben átfedik egymást (a) és ha éppen teljesen megkülönböztethetőek egymástól (b). Az (a) ábra akkor helyes, ha a két folt csúcsán a fény fázisa megegyezik, ellenkezö esetben a két folt egymást átfedö részén az ábrázolttól eltérö lenne az intenzitás.

Nem koherens megvilágítás esetén a tárgy fordított állású, kicsinyített képe áll elő a képsíkban. Mivel a tárgysík pontjainak képe átfedheti egymást, így a kép felbontását az Airy-korongok átmérője határozza meg. Koherens megvilágítás esetén a tárgy képe jellemzően nem látható, mivel a szórási interferencia véletlenszerü térerősség- és fáziseloszlást, ezzel együtt véletlenszerü intenzitás-eloszlást eredményez a képsíkban. Ennek ellenére, mint ahogy az a fejezet későbbi részében olvasható, különös figyelmet kell fordítani a megfelelő tárgy- és képtávolság beállítására. Mindezen tulajdonságaitól eltekintve a szubjektív szórási interferencia mintázat az objektív speckle esetében alkalmazott leírással jellemezhető [11].

\subsection{A szórási interferencia mintázat időbeli változása mozgó minta esetén: a} kontrasztelemzésen alapuló véráramlás-mérés 


\subsubsection{A szórási interferencia kontrasztelemzésen alapuló áramlásmérés alapjai}

Ha a megvilágított felület mozog, a keletkező szórási interferenciakép időben változik. Hasonló tapasztalható akkor is, ha a megvilágított területen különálló pontok mozognak. Kis sebesség esetén a kép lassan változik, nagy sebesség esetén azonban rövid idő alatt egészen átalakul. Ennek megfelelően kamerával történő megfigyelés során kellően rövid expozíciós idő alkalmazása esetén az elmozdulás elhanyagolható és a kép állandónak tekinthető, míg hosszabb expozíciós idő esetén az időben változó interferenciakép miatt a rögzített kép elmosódottá válik, és a kontrasztja lecsökken. Végtelen hosszú expozíciós idő esetén az intenzitásbeli fluktuációk teljesen kiátlagolódnak, így a keletkező kép gyakorlatilag megegyezik a nem koherens megvilágításnál keletkezővel.

A lézeres szórási interferencia kontrasztelemzésen (az angol nyelvű szakirodalomban „Laser Speckle Contrast Analysis”, LASCA néven találkozhatunk vele) alapuló véráramlásmérés (perfúziómérés) nagy népszerüségnek örvend Fercher és Briers 1981-es tanulmányának megjelenése óta [21], melyet hatékonyságának, egyszerü alkalmazhatóságának és viszonylag kis költségének köszönhet. Biológiai szövetek esetén jellemzően vörös vagy közeli infravörös lézerfényt alkalmaznak, mivel - mint ahogy azt a dolgozat korábbi részében tárgyaltam - ennek szórásáért leginkább a szövetben található vörösvértestek felelősek, emellett az ennél rövidebb hullámhosszú fénysugarak már nagyon kis mélységben teljesen elnyelődnek.

A LASCA során a rögzített kép különböző területein kiszámítják a lokális kontrasztot, és ez alapján egy kontraszttérképet alkotnak. A lokális kontrasztot ((32) formula) nevéből adódóan - egyszerre kis (jellemzően $5 \times 5$ vagy $7 \times 7$ pixelnyi) területen határozzák meg. Sajnos 1981-ben még nem álltak rendelkezésre olyan nagy teljesítményü általános célú számítógépek, amelyek alkalmasak lettek volna a kontraszttérképek valós időben történő kiszámítására és kiértékelésére, így több mint 10 évet kellett várni a módszer szélesebb körű elterjedésére. A 11. ábrán az 1981-es publikáció képei láthatóak. 

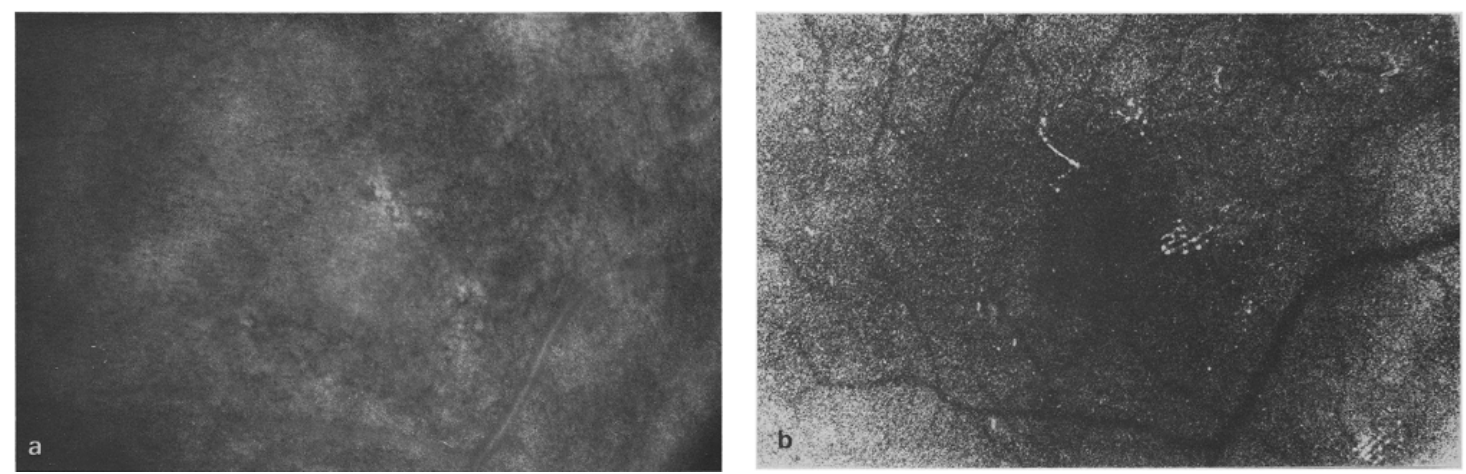

11. ábra. Az agyfelszínröl készült szórási interferenciakép (a) és az annak vérellátását bemutató elsö kontraszttérkép (b) [21]

Ahhoz, hogy megértsük, hogyan lehet a kontraszt alapján következtetni az áramlás vagy a perfúzió erősségére, a következő gondolatmenet szükséges. A detektor vagy fényérzékeny chip felszínén lévő valamely ponton mért elektromos térerősség időbeli változásait jellemző autokorrelációs függvény

$$
g_{1}(t)=\frac{\left\langle E(t) \cdot E^{*}(t+\Delta t)\right\rangle_{t}}{\langle I\rangle_{t}},
$$

ahol $E(t)$ a térerősség értéke adott időpontban, $E^{*}(t)$ ennek komplex konjugáltja. $g_{1}$ sok esetben negatív exponenciális alakban közelíthető, azonban a mozgó elemek Lorentzi sebességeloszlása esetén pontosan a következő alakot ölti:

$$
g_{1}(t)=\exp \left(-\frac{t}{\tau}\right)
$$

ahol $\tau$ a detektor vagy fényérzékeny chip felszínén lévő valamely ponton mért elektromos térerősség időbeli változásaihoz tartozó autokorrelációs idő, melyre a továbbiakban korrelációs idő néven fogok hivatkozni. Ugyanez a korrelációs idő jellemző ugyanezen pontban az intenzitás változásaira is. A Lorentzitől eltérő sebességeloszlások esetén természetesen $g_{1}(t)$ alakja is különbözik: Brown-mozgás esetén $g_{1}(t) \sim \exp (-\sqrt{t / \tau})$, Gaussi sebességeloszlás esetén pedig $g_{1}(t) \sim \exp \left(-(t / \tau)^{2}\right)$ [22], azonban a Lorentzi sebességeloszlásra jellemző alak a legegyszerübben kezelhető, és - ahogy dolgozatom későbbi részéből kiderül - kiválóan alkalmazható az élő szövetek vérellátásának 
jellemzésére. A detektor vagy fényérzékeny chip felszínén lévő valamely ponton mért elektromos térerősség másodrendű normált autokorrelációs függvénye (azaz az intenzitás autokorrelációs függvénye)

$$
g_{2}(t)=\frac{\langle I(t) \cdot I(t+\Delta t)\rangle_{t}}{\langle I\rangle_{t}} .
$$

A térerősség és az intenzitás normált autokorrelációs függvénye között teremt kapcsolatot a Siegert-reláció [22]:

$$
g_{2}(t)=1+\left|g_{1}(t)\right|^{2} \text {. }
$$

A detektor vagy fényérzékeny chip felszínén lévő valamely ponton mért intenzitás autokovarianciájának definíciója

$$
C^{2}(t)=\left\langle\left[I(t)-\langle I\rangle_{t}\right] \cdot\left[I(t+\Delta t)-\langle I\rangle_{t}\right]_{t},\right.
$$

ennek normált változata pedig

$$
c^{2}(t)=\frac{C^{2}(t)}{\langle I\rangle_{t}^{2}} .
$$

Ha feltesszük, hogy a vizsgált minta esetén teljesül a Siegert-reláció (azaz az elektromos térerősség Gaussi statisztikai tulajdonságokkal rendelkezik), akkor (48) a következő alakot ölti:

$$
g_{2}(t)=1+c^{2}(t) .
$$

(46), (50), (51) alapján

$$
C^{2}(t)=\langle I\rangle_{t}^{2} \cdot \exp \left(-\frac{2 t}{\tau}\right)
$$


Feltételezve, hogy az intenzitás temporális és laterális statisztikai tulajdonságai megegyeznek, akkor kapcsolatot teremthetünk a vizsgált képszegmens intenzitásértékeinek szórása és az intenzitásértékek autokovarianciája között:

$$
\begin{gathered}
\sigma^{2}(T)=\frac{1}{T} \int_{0}^{T} C^{2}(t) d t, \\
K^{2}(T) \cdot\langle I\rangle^{2}=\frac{1}{T} \int_{0}^{T} C^{2}(t) d t, \\
K(T)=\left\{\frac{\tau}{2 T}\left[1-\exp \left(\frac{-2 T}{\tau}\right)\right]\right\}^{1 / 2}
\end{gathered}
$$

adódik, ahol $T$ az expozíciós idő, és $\tau$ értéke fordítottan arányos a megvilágított térfogatban mozgó szemcsék karakterisztikus sebességével [21]. Ez egy szigorúan monoton csökkenő függvény, ami lehetővé teszi a korrelációs idő meghatározását: $\lim _{T \rightarrow 0} K(T)=1$ és $\lim _{T \rightarrow \infty} K(T)=0 \quad(12$. ábra $)$.

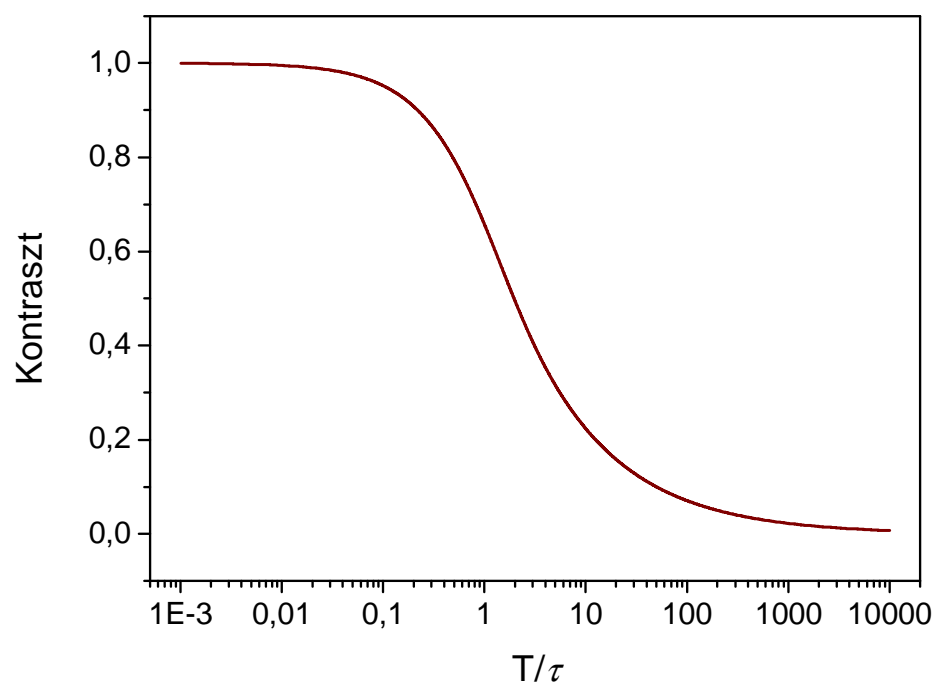

12. ábra. A kontraszt függése az expozíciós idő és a korrelációs idő hányadosától az (55) formula alapján 
A mozgásra jellemző karakterisztikus sebesség és a korrelációs idő közötti arányossági tényező függ a megvilágító lézer hullámhosszától, a szóró szemcsék jellemzőitől (méret, alak, koncentráció, közeghez viszonyított törésmutató), sebességeloszlásától és (nem gömbszimmetrikus szemcsék esetén) az orientációjától is. Bár az arányosság értéke kalibráció útján vagy egyes esetekben numerikus közelítéssel is megadható, ezt jellemzően kerülni szokták, mivel bármelyik felsorolt paraméter megváltozása hibás eredményekhez vezet [23], [24]. A legtöbb esetben a korrelációs idő reciprokjának relatív változásait az áramlás karakterisztikus sebességének relatív változásainak feleltetik meg. A korrelációs idő pontosabb meghatározására irányuló fejlesztésekről a „2.3.3. A korrelációs idő pontosabb meghatározását célzó fejlesztések” c. fejezetben találhat áttekintést az Olvasó.

\subsubsection{A kontraszt pontosabb meghatározását célzó fejlesztések}

A LASCA során a lokális kontrasztértékeket jellemzően $5 \times 5$ vagy $7 \times 7$ pixelnyi területen határozzák meg [24]. Mivel az intenzitásértékek véletlenszerüek, így a mérések eredményei jelentős zajjal terheltek. Ennek következtében a kontraszt meghatározása annál pontosabb, minél nagyobb a figyelembe vett foltok száma. Kellően sok folt megfigyeléséhez nagyszámú pixel értékét kell számításba venni, ami azonban a módszer laterális feloldóképességét csökkenti. A képeken elérhető kontrasztot a speckle foltok és a fényérzékeny chip pixeleinek mérete is befolyásolja. Nyilvánvaló, hogy ha egy pixelre (detektorszegmensre) egyszerre több interferencia maximum (és minimum) esik, akkor az interferenciakép valódi kontrasztját nem lehet meghatározni. Ha azonban egy folt mérete jóval nagyobb egy pixelnél, sok pixel intenzitását kell figyelembe venni a lokális kontraszt meghatározásához, ami rontja a laterális felbontást. Kirkpatrick és munkatársai kimutatták, hogy a legjobb eredmény eléréséhez a speckle foltok átlagos átmérőjének meg kell haladnia a pixelek oldalhosszának kétszeresét [26]. Thompson és munkatársai további méréseket végeztek arra vonatkozóan, hogy a pixelek, az interferencia foltok, illetve a lokális kontraszt meghatározásához használt terület nagysága hogyan befolyásolja az átlagos lokális kontraszt értékét [27]. A 13. ábrán Thompson és munkatársainak eredeti eredményei láthatóak az interferenciafoltok átlagos átmérőjét és a pixelek oldalhosszát illetően. A 14. ábrán pedig a lokális kontraszt értékét mutatja be a lokális kontraszt meghatározásához használt ablak oldalhosszának és az interferencia foltok átmérőjének függvényében. 


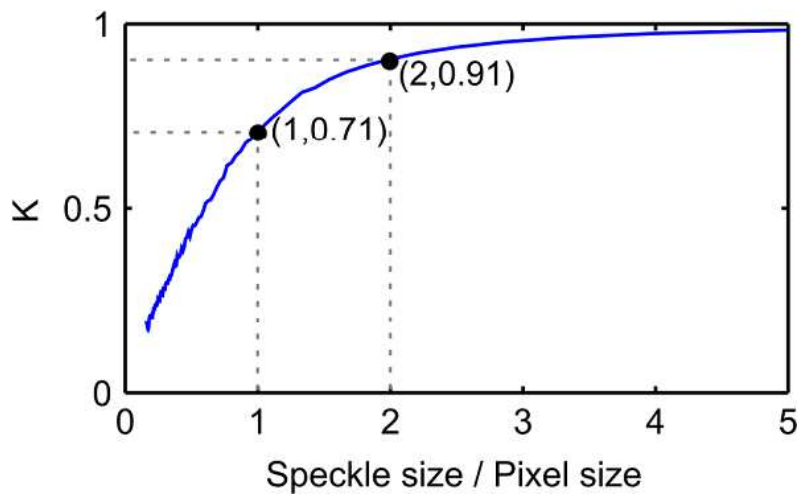

13. ábra. A kontraszt (K) értéke az interferencia foltok átméröje (speckle size) és a pixelek oldalhossza (pixel size) hányadosának függvényében [27].

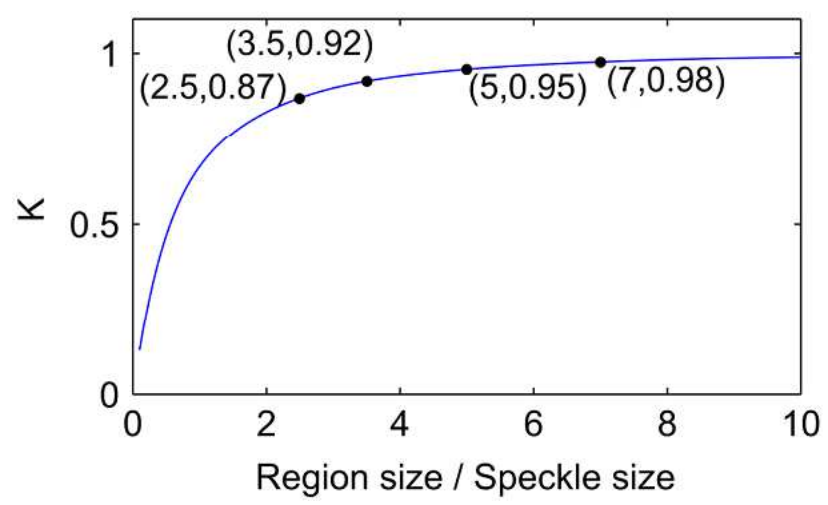

14. ábra. A kontraszt (K) értéke a lokális kontraszt számításához használt ablak oldalhossza (region size) és az interferencia foltok átlagos mérete (speckle size) hányadosának függvényében [27].

Kirkpatrick és munkatársai, valamint Thompson és munkatársai eredménye alapján az interferencia foltok átlagos átmérőjének legalább kétszer akkorának kell lennie, mint a fényérzékeny chip pixeleinek oldalhossza, illetve a lokális kontraszt kiszámításához használt ablak oldalhosszának legalább 3,5-szer akkorának kell lennie, mint az interferencia foltok átlagos mérete. Ezek alapján a kontrasztelemzést $7 \times 7$ pixelnyi területeken kellene elvégezni, ami a lokális kontrasztértékekből alkotott kontraszttérképek esetén alacsony laterális felbontást eredményezne. Kompromisszumos megoldásként az interferenciafoltok méretét akkorának választják, hogy az összemérhető legyen egy pixellel, a kontrasztelemzést pedig $5 \times 5$ pixeles területeken végzik [28].

A szórási interferencia kontrasztelemzés jellegéből adódó jelentős statisztikai zaj csökkenthető több kontraszttérkép átlagolásával, azonban a módszer csak abban az esetben alkalmazható, ha a vizsgált minta nem mozdulhat el a mérés során (15. ábra). 

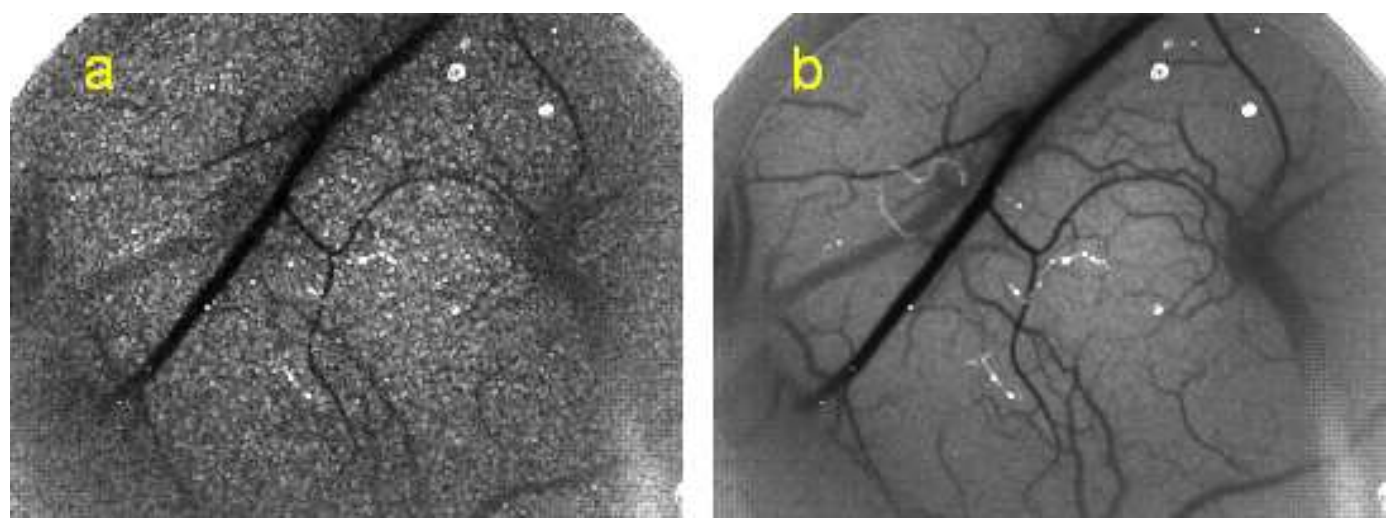

15. ábra. Malac agykérgéröl készült egyetlen kontraszttérkép (a) és húsz kontraszttérkép átlaga $(b)$

A statikus elemek jelenléte különösen zavaró az időbeli kontrasztelemzés során, amikor nem egyetlen szórási interferenciakép $5 \times 5$ vagy $7 \times 7$ pixelnyi területe, hanem számos $(20$ 200) egymást követő kép ugyanazon pixele alapján számítják ki a kontrasztot [29]. A statikus elemek ekkor alacsony kontrasztot eredményeznek, ami pedig az (55) formula alapján nagy sebességnek felel meg. Völker és munkatársai [30] kidolgoztak egy módszert, amely kiküszöböli ezt a hibát. A lézerdióda és a minta között egy diffúzort helyeztek el, melyet lassan forgattak, ezáltal a kamera a kép minden területén folytonosan változó speckle mintázatot érzékelt. A diffúzor forgatási sebességét úgy állították be, hogy a forgással járó intenzitásváltozás autokorrelációs ideje jóval meghaladja az expozíciós időt, így az egyes expozíciók során elhanyagolható volt a megvilágítás mintázatának változása. Ugyanakkor az egyes képkockák között a forgással járó autokorrelációs időnél hosszabb idő telt el, így két egymást követő képkocka egymáshoz képest teljesen dekorrelált lett. Csak ezután számították ki a kontraszttérképek átlagát, amelyeken - az egymást követő képek teljes dekorreláltsága miatt - már nem volt jelen a mozdulatlan elemek nem okozta kontrasztcsökkenés.

A mérőrendszer beállítása során nagy figyelmet kell fordítani arra is, hogy a minta a leképező rendszer tárgysíkjában legyen, mivel ellenkező esetben a kamera egy adott pixelére nagyobb területről is érkeznek fotonok, ennek következtében elmosódottá válik a kontraszttérkép (16. ábra). 

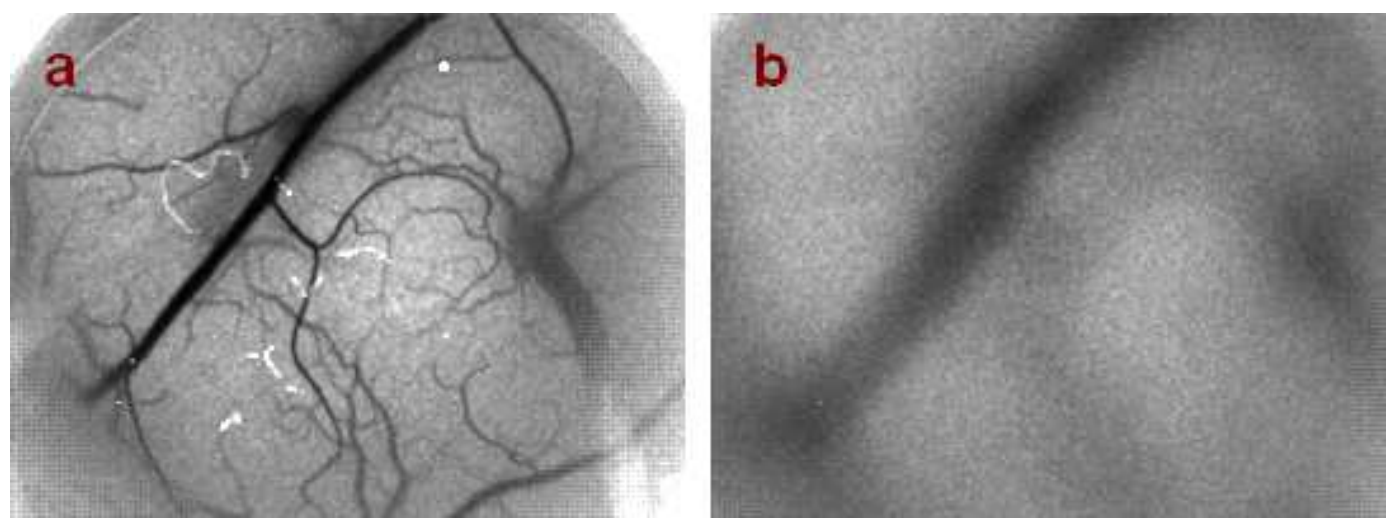

16. ábra. Helyesen (a) és helytelenül (b) beállított fókusztávolsággal készült képek alapján számított 20 kontraszttérkép átlaga

A tisztán tér- és időbeli kontraszton alapuló mérőrendszerek előnyeinek ötvözése érdekében kifejlesztettek kombinált módszereket is. Ezek esetében nem egyetlen kép $5 \times 5$, vagy 25 egymást követő kép ugyanazon pixelének intenzitásértékei alapján határozzák meg a lokális tér- vagy időbeli kontraszt értékét, hanem például három egymást követő kép $3 \times 3$ pixelnyi része (tehát összesen 27 pixel) alapján, így egyszerre nyújt viszonylag nagy tér- és időbeli felbontást [31]-[33].

\subsubsection{A korrelációs idő pontosabb meghatározását célzó fejlesztések}

A Fercher és Briers által kidolgozott, nagyobb pontosságot biztosító, függvényillesztésen alapuló módszerrel kapcsolatban Bandyopadhyay és munkatársai kimutatták, hogy statisztikai megfontolásokból érdemes a gyors változásokat nagyobb súllyal figyelembe venni, bevezetve egy (1-t/T) szorzótényezőt az (54) és (55) egyenletben szereplő integrálba [36]:

$$
\begin{gathered}
K^{2}(T) \cdot\langle I\rangle^{2}=\frac{1}{T} \int_{0}^{T}\left(1-\frac{t}{T}\right) \cdot C^{2}(t) d t, \\
K(T)=\left\{\frac{\tau^{2}}{2 T^{2}}\left[\exp \left(\frac{-2 T}{\tau}\right)-1+\frac{2 T}{\tau}\right]\right\}^{1 / 2} .
\end{gathered}
$$

Ez szintén egy szigorúan monoton csökkenő függvény, ami lehetővé teszi a korrelációs idő meghatározását: $\lim _{T \rightarrow 0} K(T)=1$ és $\lim _{T \rightarrow \infty} K(T)=0$. Megvizsgáltam, hogy a Fercher és Briers 
által kidolgozott, és a Bandyopadhyay és munkatársai által megalkotott összefüggés segítségével illeszthető görbék mennyire különböznek egymástól. Úgy találtam, hogy a két görbe egy konstans szorzófaktornyi eltolástól eltekintve jól egyezik egymással, ahogy azt a 17. ábra is mutatja.

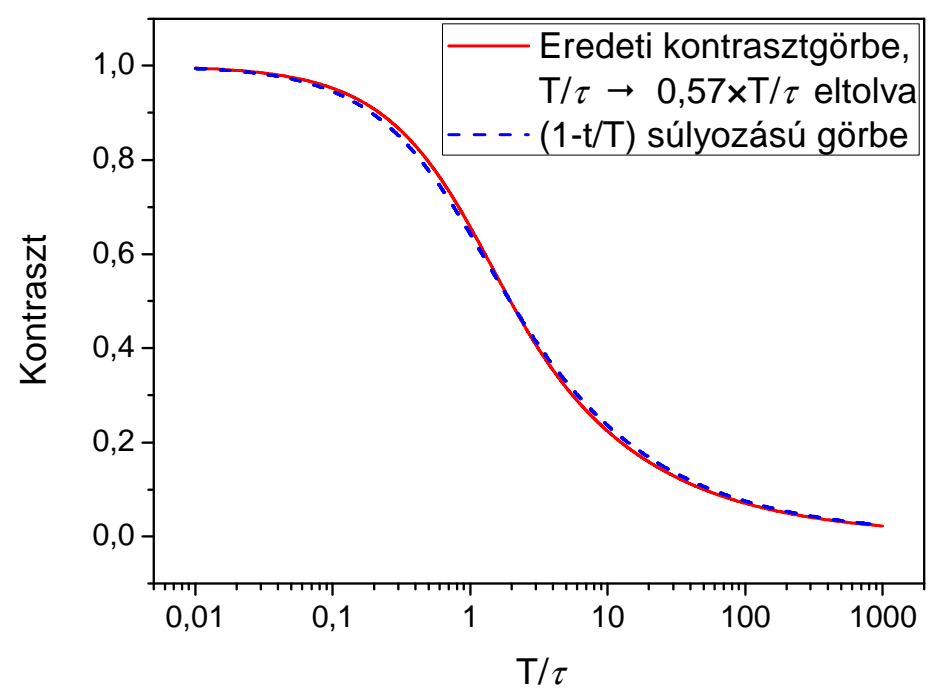

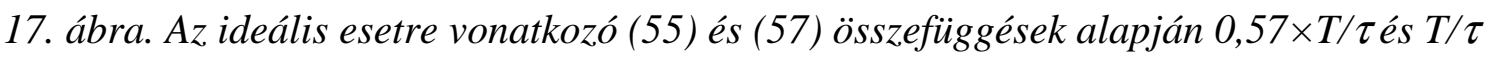
szerint rajzolt kontrasztgörbék. Jól látható, hogy a görbék lefutása nagyon hasonló, a $\tau$ illesztési paraméter pedig csak egy konstans szorzó erejéig tér el egymástól.

Valós méréseknél a megvilágítás tökéletlensége, a detektor véges mérete, a többszörös szóródás, a pixelek és a foltok eltérő mérete, valamint számos további nem ideális körülmény miatt a kontraszt nem éri el az 1 értéket, ezért Lemieux és Durian bevezették a $\beta$ korrekciós faktort, melynek értéke $\beta=\lim _{T \rightarrow 0} K_{\text {valoss }}^{2}(T)$ [37]. Így az (57) összefüggés a következőképpen módosul:

$$
K(T)=\left\{\beta \frac{\tau^{2}}{2 T^{2}}\left[\exp \left(\frac{-2 T}{\tau}\right)-1+\frac{2 T}{\tau}\right]\right\}^{1 / 2}
$$

$\beta$ numerikus modellezéssel történő meghatározása rendkívül nehéz feladat, ezért a valós méréseknél egy megfelelő mozdulatlan felület (pl. papír, Teflon tömb) kontraszttérképe alapján szokták megállapítani a rendszerre jellemző értékét. 
A LASCA eljárást széles körben használják a perfúzió mérésére az agykéreg [38], [39] és a szemfenék [40]-[42] esetén. (Mivel a szövetekben a kapillárisok szintjén már nincs kitüntetett áramlási irány, az áramlás helyett perfúzióról beszélhetünk.) Általában egyetlen expozíciós időt alkalmaznak a mérések során, és a $\beta$ korrekciós faktort minden mérés előtt meghatározzák. A mérések során valójában az $1 / \tau$ tényleges értéke helyett annak relatív változásait szokták megfeleltetni a véráramlásban bekövetkező változásoknak, mivel a megfigyelt szövet szórási tulajdonságai, valamint a méréshez használt eszköz paraméterei befolyásolják a szövetre jellemző aktuális $\beta$ (és ezáltal a mérés során kapott $1 / \tau$ ) értékét. Az 1/ $\tau$ mennyiségre a továbbiakban reciprok korrelációs idő néven is fogok hivatkozni.

Az (58) összefüggésnek van még egy jelentős, különösen a börszövetek vizsgálata esetén jelentkező hiányossága: míg az összefüggés végtelen hosszú expozíciós idő esetére nullára csökkenő kontrasztot jósol, a gyakorlatban ez korlátozottan vagy egyáltalán nem teljesül. A mozdulatlan részekről történő fényszóródás egy állandó szórási interferencia mintázatot hozhat létre, melyhez hozzáadódik az időben változó komponens. Ez végtelen nagy expozíciós idő esetén is 0-nál lényegesen nagyobb kontrasztot eredményez, így a fent leírt módszer segítségével meghatározott relatív $1 / \tau$ értékek csak egy mérési sorozaton belüli kvalitatív összehasonlításra alkalmasak. Bár a probléma már régebben is ismert volt [43], csak 2006-ban jelent meg olyan közlemény, melyben a szerzők kvantitatív leírást adtak a jelenségre [45].

A teljesség kedvéért szeretnék még három, a cerebrovaszkuláris illetve okuláris kutatások terén elterjedt egyszerű, kis számításigényű módszert bemutatni. A területen elterjedt első közelítő összefüggés a normált elmosódás (normalized blur, NB), melynek definíciója

$$
N B=\frac{\langle I\rangle}{\langle\langle I\rangle-I\rangle\rangle} .
$$

Tamaki és munkatársai [33] méréseik során megmutatták, hogy a normált elmosódás jó közelítéssel arányos az áramlási sebességgel. A normált elmosódás és a reciprok korrelációs idő kapcsolatát szemléltati a 18. ábra. 


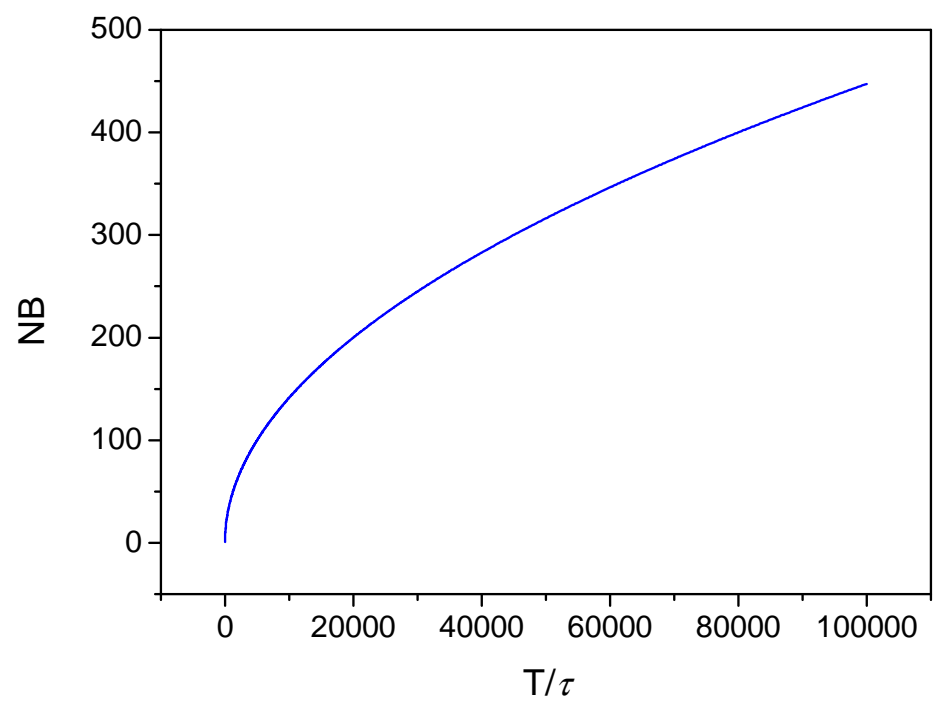

18. ábra. Az NB az expozíciós idő és a korrelációs idő hányadosának függvényében. Jól látszik, hogy a mennyiség csak szük tartományokon tekinthetö közelítöleg arányosnak $1 / \tau$ val.

A másik elterjedt közelítés a négyzetes elmosódás (square blur rate, SBR), melynek segítségével szintén meghatározható lehet a $v$ áramlási sebesség. Ennek elmélete szerint

$$
\begin{gathered}
v \sim \frac{\langle I\rangle^{2}}{\sigma^{2}}=N B^{2}, \\
S B R=C \cdot \frac{\langle I\rangle^{2}}{\sigma^{2}}-\text { offset, }
\end{gathered}
$$

ahol $C$ és offset meghatározása kísérleti úton történik. Ily módon az áramlási sebesség egy additív tagtól eltekintve - arányosnak adódik a négyzetes elmosódással, ami jelentősen egyszerüsíti a kiértékelés során elvégzendő számításokat [33], [35] A négyzetes elmosódás és a reciprok korrelációs idő kapcsolatát szemlélteti a 19. ábra. Az NB és az SRB kapcsolata meglehetősen szoros a (32) formulával definiált kontraszttal:

$$
N B^{2}=S B R=\frac{1}{K^{2}}
$$


Bár a fejezetben leírtak alapján egyértelmủen kiderül, hogy az áramlási sebesség és a kontraszt kapcsolata lényegesen szofisztikáltabb a kutatók által feltételezettnél, az $1 / K^{2}(T)$ függvény valóban jó közelítéssel lineáris a $T>2 \tau$ tartományon, így az expozíciós idő körültekintő megválasztásával valóban alkalmazható az SBR az áramlás sebességének közvetlen megbecsülésére. Ramirez-San-Juan és munkatársai is hasonló eredményre jutottak [43].

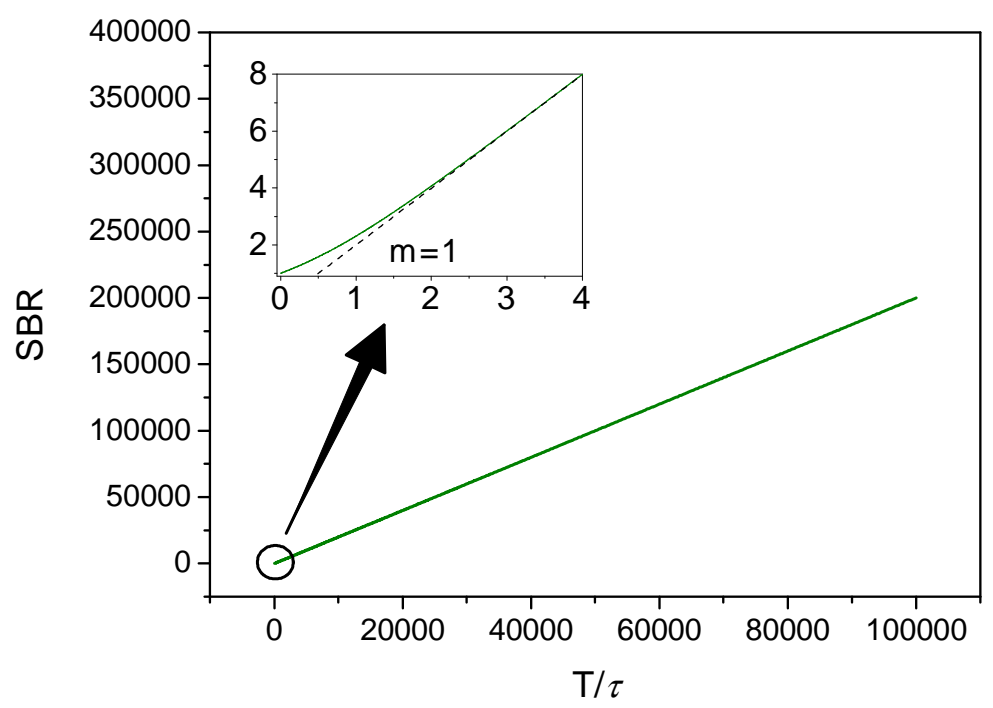

19. ábra. Az SBR az expozíciós idő és a korrelációs idő hányadosának függvényében. Jól látszik, hogy $T>2 \tau$ esetén a mennyiség jó közelítéssel arányos $1 / \tau$-val, azaz az áramlási sebességgel. Az ábra bal felső sarkában a görbe kezdeti, nem lineáris szakasza látható, segítségképp az $m=1$ egyenessel (szaggatott vonal).

Az áramlási sebesség közvetlen megbecsülésére használt harmadik mennyiség az átlagos elmosódás (mean blur rate, MBR):

$$
\begin{gathered}
M_{m, n}=\sum_{i=-k}^{k} \sum_{j=-k}^{k} I_{m+i, n+j}+I_{m, n}, \\
D_{m, n}=\sum_{i=-k}^{k} \sum_{j=-k}^{k}\left|I_{m+i, n+j}-I_{m, n}\right|, \\
M B R_{m, n}=\frac{M_{m, n}^{2}}{D_{m, n}^{2}},
\end{gathered}
$$


ahol $m$ és $n$ a vizsgált kép adott indexü pixelét jelölik, $k$ pedig a vizsgált képszegmens méretét határozza meg. Konishi és munkatársai munkájukban [31] bemutatták, hogy az MBR arányos az áramlási sebességgel.

\subsection{Alternatív módszerek a perfúzió mérésére}

A vörösvértestek áramlási sebességének meghatározására egy elterjedten alkalmazott módszer a lézeres Doppler módszer. A legegyszerübb készülékek esetén a lézer fénye egy optikai szálon keresztül jut el a vizsgált szövethez, majd a szövetben szóródó és Dopplereltolódást szenvedő fény ugyanezen a szálon jut vissza a készülékbe. Az eszköz összehasonlítja a visszaszórt fény hullámhosszát a fényforráséval, így megállapítja az elöbbi Doppler-eltolódásának és így sebességének spektrumát.. Ezen eszközöket rendszeresen kalibrálni kell a gyártó által biztosított mozgási standard (,motility standard”) segítségével. Legfőbb hátrányuk az, hogy minden tappancs segítségével egyszerre csupán hozzávetőleg 1-1 $\mathrm{mm}^{3}$ térfogatban képesek mérni a szövet vérellátását. Egy ilyen eszközzel találkozhat az Olvasó az 5-8. fejezetekben.

$\mathrm{Az}$ előbbinél lényegesen fejlettebb eszköz a pásztázó Doppler-rendszer. Ez egy tükörrendszer segítségével a minta különböző pontjaira irányítja a lézersugarat, majd a visszaszóródó fényt egy detektorral vizsgálja [44]-[47]. Bár a módszer egyelőre jóval nagyobb pontosságú méréseket tesz lehetővé, mint a LASCA, óriási hátránya, hogy egy megfelelő felbontású (> 100×100 pont) kép elkészítése akár több percig is eltarthat (pl. egy 232×174 mérési pontból álló terület vizsgálata a pásztázó Doppler-módszerrel 3,7 percig tartott [44]) és ez idő alatt az élő szövet vérellátása jelentősen megváltozhat. Mivel a pásztázási sebesség növelésére a mérési pontosság drasztikus csökkenése nélkül nincs lehetőség, az akár valós idejű megfigyeléseket jóval nagyobb térbeli felbontás mellett lehetővé tevő LASCA ígéretes alternatíva lehet. A 20. ábrán egy pásztázó Doppler rendszerrel készített felvétel látható az alany kezéről kezdeti állapotban (bal oldalt) és egy horzsolás ejtése után (jobb oldalt). A 21. ábrán hasonló körülmények között, ugyanazon alany másik kezéről egy LASCA rendszerrel készült felvételek láthatóak, amelyeken az (55) összefüggés alapján határozták meg a szövet pillanatnyi vérellátását. 

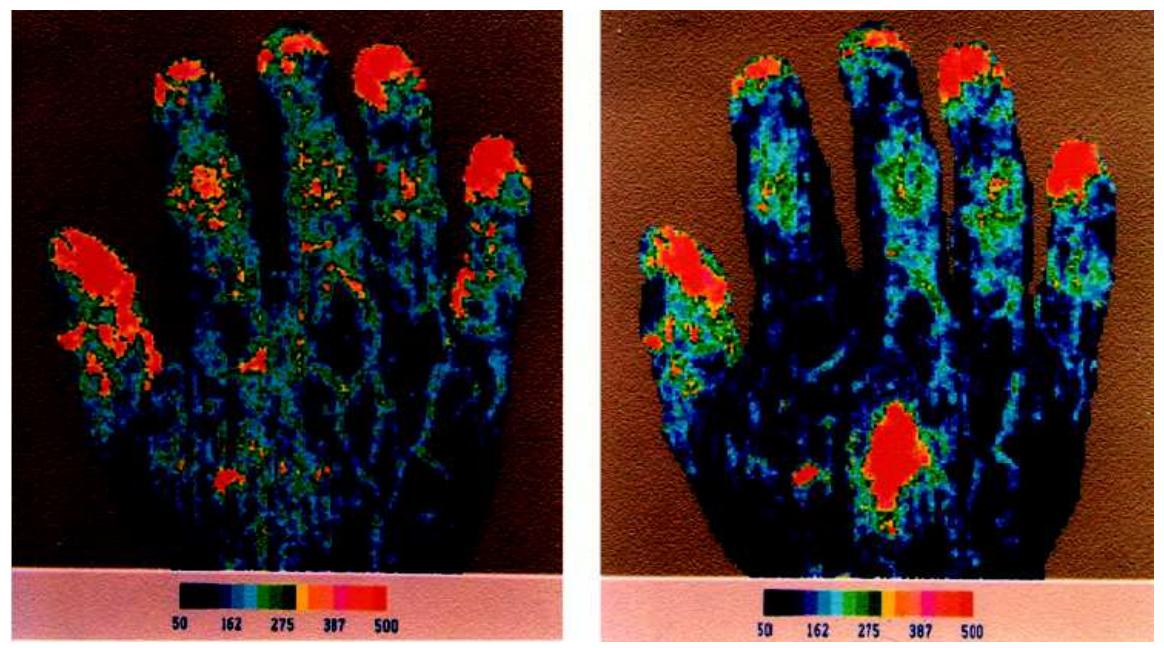

20. ábra. Pásztázó Doppler rendszerrel készitett kép a jobb kézről sérülés elött és után [44]
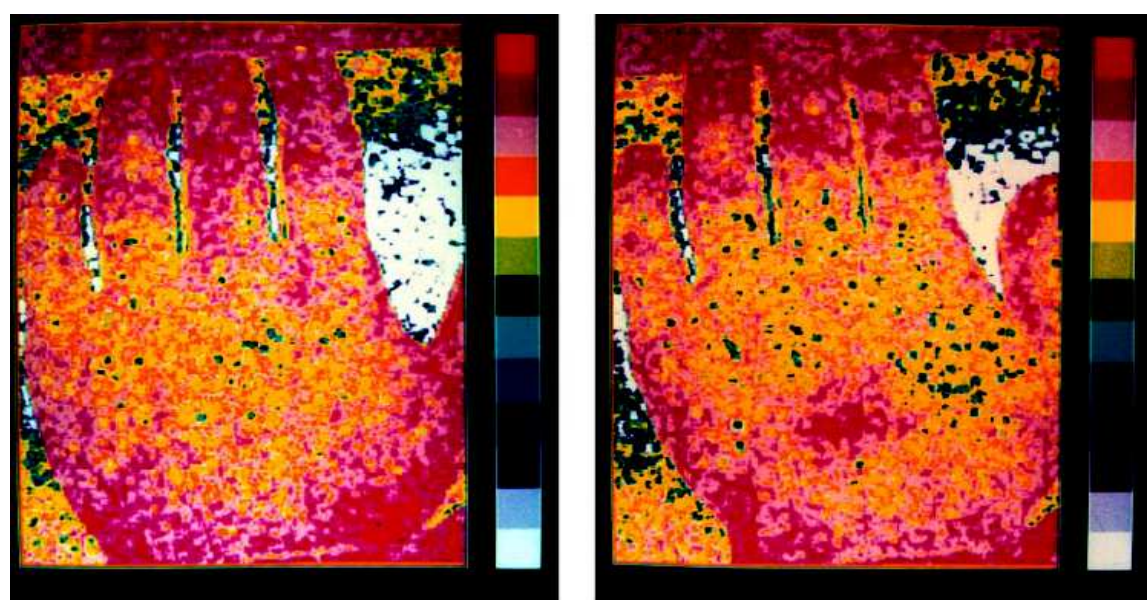

21. ábra. LASCA módszerrel készített kép a bal kézről sérülés előtt és után [44]

A 20. és 21. ábra között jól látható különbség legfőbb oka a bőrfelszín jelentős statikus szórása, amely a Doppler-rendszerrel mért értékeket nem befolyásolja, de jelentősen torzítja az egyetlen expozíciós időt alkalmazó LASCA rendszerrel kapott eredményt [44].

Meg kell említeni, hogy már léteznek olyan kísérleti stádiumban levő lézeres Dopplerrendszerek, amelyek valós idejü megfigyelést is lehetővé tesznek. Ezekben egy $10 \mathrm{kHz}$ feletti mintavételi sebességű kamerát használnak, és az egyes pixelek intenzitásváltozásaiból Fourier-transzformációval határozzák meg a vörösvértestek pillanatnyi sebességét [48]-[50]. Bár ezen innovatív rendszerek nagy pontossággal, valós időben képesek meghatározni a vér áramlási sebességét, az alkalmazott kamerák magas ára (több tízmillió Ft) erősen korlátozza a módszer széleskörű elterjedését. 
A lézeres szórási interferencia kontrasztelemzéssel meghatározott eredményeket hagyományosan lézeres Doppler mérésekkel szokták összevetni, mivel az - elméletileg képes kvantitatív módon jellemezni a vizsgált szövet vérellátását. Érdemes megvizsgálni a lézeres Doppler és a lézeres szórási interferencia során keletkező jel kapcsolatát. Thompson és munkatársai [50] megmutatták, hogy a két módszer azonos gyökerekre vezethető vissza. Induljunk ki az (56) egyenlet kissé módosított alakjából:

$$
\sigma^{2}=\int_{0}^{T}\left(1-\frac{t}{T}\right) C_{T}(t) d t
$$

ahol az autokovariancia $C_{\mathrm{T}}(t)$ alakban szerepel $C^{2}(t)$ helyett. Ezt átrendezve

$$
\sigma^{2} T^{2}=\int_{0}^{T}(T-t) C_{T}(t) d t
$$

adódik. $T$ szerint kétszer differenciálva

$$
\begin{gathered}
\frac{d}{d T} \sigma^{2} T^{2}=\int_{0}^{T} C_{T}(t) d t \\
\frac{d^{2}}{d T^{2}} \sigma^{2} T^{2}=C_{T}(t),
\end{gathered}
$$

majd felhasználva a kontraszt $K=\sigma /\langle I\rangle$ definícióját

$$
C_{T}(t)=\frac{d^{2}}{d T^{2}} K^{2} T^{2}\langle I\rangle^{2}
$$

adódik. Szimulációk és kísérletek segítségével megmutatták, hogy több expozíciós idő alkalmazása esetén az autokovariancia alapján számított spektrális teljesítménysűrüség jó egyezést mutat a Doppler mérések során meghatározott spektrális teljesítménysűrüséggel.

Bár nem kapcsolódik szorosan a lézeres szórási interferencia kontrasztelemzésen alapuló áramlásméréshez, szeretnék megemlíteni néhány további, a cerebrovaszkuláris kutatások során alkalmazott módszert, melyekkel a szövet vérellátása vizsgálható. 
Doppler-méréseket nem csak lézersugárzás, hanem ultrahang segítségével is lehet végezni. Az ultrahangok viszonylag nagy behatolási mélysége, az eszköz egyszerű alkalmazhatósága és a módszer veszélytelensége miatt elterjedten alkalmazzák a nyaki erekben folyó vér sebességének meghatározására. Mivel egy ér esetén az átfolyt vér mennyisége arányos a sebesség, a belső keresztmetszet és az eltelt idő szorzatával, az eszköz segítségével gyorsan és egyszerüen meghatározhatóak az agy vérellátásában bekövetkező változások.

A cerebrovaszkuláris kutatások során elterjedten alkalmazzák az MRI (Magnetic Resonance Imaging, mágneses magrezonancia képalkotás) rendszereket a szövetek szerkezetének és vérellátásának vizsgálatára. A módszer előnye, hogy a pácienst nem éri ionizáló sugárterhelés, hiszen rádiófrekvenciás sugárzás és mágneses tér van jelen az eszközben. Hátránya, hogy a hatékony vizsgálathoz kontrasztanyagra van szükség, ami egyes esetekben allergiás reakciót válthat ki, illetve az eljárás segítségével a vízterek változásai követhetőek nyomon, amiből áttételesen lehet következtetni a szövet vérellátásában bekövetkező változásokra.

Az erek és az áramlás feltérképezésére CT (Computer Tomography, számítógépes tomográfia) is alkalmazható, ha angiográfiával kombinálják. Bár a CT segítségével elsősorban az érhálózat struktúrája deríthető fel, a páciens véráramába a röntgensugárzást jól elnyelő kontrasztanyagot juttatva feltérképezhető a kontrasztanyag szétterjedése a szervezetben, illetve a szétterjedést követően a teljes érhálózat is (legalább $1 \mathrm{~mm}$ átmérőjü erekre). A módszer hátránya, hogy páciens sugárterhelésnek van kitéve, illetve kontrasztanyagot kell alkalmazni, ami kellemetlen és egyes esetekben allergiás reakciót válthat ki.

A CT segítségével feltérképezhető a szövetek vérellátása akkor is, ha a vérbe juttatott kontrasztanyag alkalmazása helyett xenon gázt lélegeztetnek a pácienssel. A xenon diffúzió útján jut el a szövetekbe, és így kimutatható, mely szövetek vérellátása intenzívebb.

Optikai koherencia tomográfia segítségével egy nem túl nagy területen ma már feltérképezhető a mozgó vörösvértestek mennyisége és sebessége. A módszer legföbb hátránya a szükséges eszközök igen magas költsége.

A véráramlás úgy is jellemezhető, ha a keringési rendszerbe mikrogömböket juttatnak. Fluoreszcens festéket tartalmazó gömbök esetén ezek egy UV fényforrást alkalmazva a felszíni erekben láthatóvá tehetők. Az elhaladó mikrogömböket megszámolva jellemezhető az áramlás egy adott érszakaszon is. Ha a mikrogömbök radioaktív izotópokat 
tartalmaznak, akkor a szövet sugárzása alapján jellemezhető a vizsgált szövet vérellátása. A módszer legföbb hátránya az, hogy ha a mikrogömbök feldúsulnak egy területen, akkor ott eltömíthetik az ereket.

Végül egy olyan módszert szeretnék megemlíteni, amelynek segítségével kvantitatívan jellemezhető a kapillárison átáramló vér mennyisége. Ha a hajszáleret egy mikroszkóppal vizsgálják, akkor láthatóvá válnak az egyes vörösvértestek. Egy alkalmas eszközzel automatikusan megszámolhatóak az áthaladó vörösvértestek, és így az átáramló vér mennyisége kvantitatívan leírható. 


\section{Célkitűzés}

A LASCA eljárással viszonylag egyszerüen meg lehet határozni a véráramlást agykéreg vagy szemfenék vizsgálata során, azonban még nem dolgoztak ki olyan módszert, amelynek segítségével egymással számszerủen összehasonlítható, eszközfüggetlen eredményeket kaphatunk akkor is, ha a vizsgált szövetek jelentős statikus szórással rendelkeznek. Kutatásom célja a LASCA alkalmazhatóságának kiterjesztése és egy olyan eszköz alapjainak a lefektetése volt, ami a mindennapi gyakorlatban is könnyen használható. Azt tüztem ki célul, hogy ezzel az eszközzel lehetővé váljon a különféle összeállításokkal készült eredmények közel valós időben történő, kvantitatív összehasonlítása.

- Először a mérések elvégzéséhez és kiértékeléséhez szükséges szoftveres hátteret terveztem biztosítani. Egy olyan mérési protokollt kívántam megalkotni, ami alkalmas több expozíciós idő felhasználásával képeket rögzíteni utólagos kiértékeléshez.

- A mérések első lépésként egy, a szövetek felépítését utánzó modellt kívántam elkészíteni, mellyel vizsgálható a mozdulatlan szóró centrumok hatása a kialakuló interferenciakép kontrasztjára. Ennek eredményei alapján célom egy olyan módosított kontraszt-expozíciós idő összefüggés felírása volt, mely egy megfelelő mintavételezési eljárással együtt alkalmas a statikus szórás hatásainak figyelembevételére a valódi korrelációs idő meghatározása érdekében.

- A protokoll és az eszközpark további fejlesztése nyomán a mérőrendszert alkalmassá szerettem volna tenni valós idejű mérések elvégzésére és azok automatikus kiértékelésére is. Egy olyan, a dolgozat megírásáig a területen nem alkalmazott újítást kellett bevezetnem, ami kiemelkedő költséghatékonyság mellett lehetővé tette az expozíciós idő képkockáról képkockára történő hangolását. Mivel a képrögzítés és feldolgozás legalább 4, egyenként 0,1-0,3 másodperc hosszú lépésböl állt, különösen nagy kihívást jelentett a program egyes elemeinek optimalizálása és párhuzamosítása annak érdekében, hogy a mérőrendszer képes legyen másodpercenként öt kép rögzítése és feldolgozására.

- Kísérleteim második szakaszában az általam kidolgozott módszert valós mérési körülmények között kívántam tesztelni, melyhez bőrszöveti és agykérgi perfúzió méréseket kívántam elvégezni. 


\section{Kísérleti elrendezés}

A kísérletekhez használt elrendezés saját építésű, a 22. ábrán az első változata látható. A kutatás előrehaladtával az elrendezés és a mérési módszerek is folyamatos fejlődésen mentek keresztül, a dolgozat megfelelő részeinél jelezni fogom ezeket a változásokat.

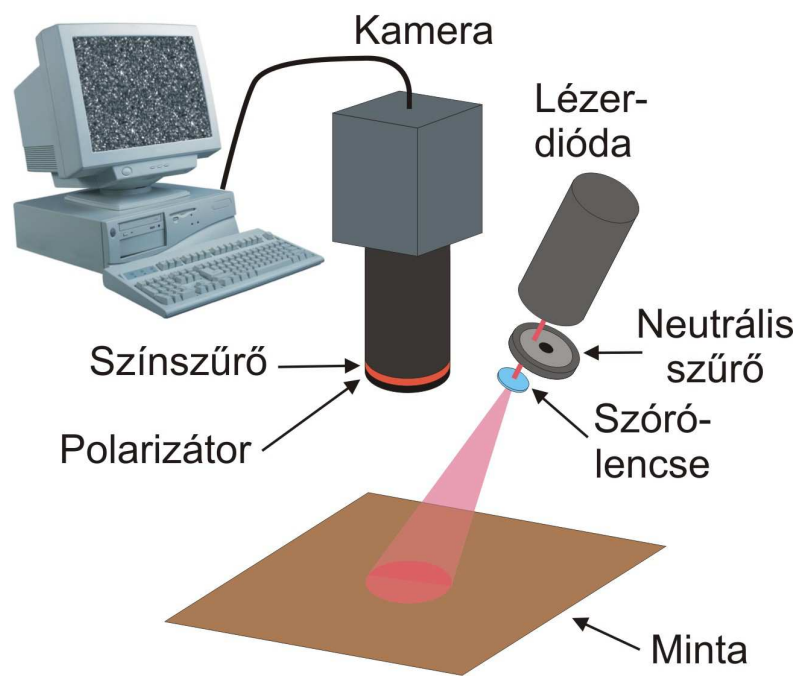

22. ábra. A mérések során használt mérési elrendezés vázlata

\subsection{Megvilágítás}

A vizsgált terület megvilágítását egy $130 \mathrm{~mW}$ teljesítményü, $660 \mathrm{~nm}$ hullámhosszú (ADL-66Z01HL), vagy egy $200 \mathrm{~mW}$ teljesítményü, $808 \mathrm{~nm}$ hullámhosszú (ADL80Y01TZ), polarizált fényü, egymódusú lézerdióda biztosította. A lézerdióda meghajtását egy Thorlabs LDC220C típusú stabilizált áramforrás látta el. A lézerdióda hűtését kezdetben csak egy passzív foglalat látta el, azonban hamar nyilvánvalóvá vált, hogy csekély mértékü hőmérsékletváltozás is nem kívánt módusugrásokhoz vezet (az interferenciakép, valamint a kontraszt jelentős változását eredményezve), lehetetlenné téve több órán keresztül tartó folyamatos mérések elvégzését. Ezért a lézerdiódát egy Thorlabs LDM21 típusú Peltier-elemmel ellátott aktív hőmérsékletszabályozású foglalatba helyeztem, melynek vezérléséről egy Thorlabs TED200C típusú tápegység gondoskodott. Sajnos a megvilágítás intenzitását a módusugrások miatt nem lehetett a meghajtó áramerősséggel szabályozni, a blende átmérőjének átállítása pedig az interferencia foltok méretének változásához vezetett volna. Ezen okok folytán a megvilágító fény intenzitását 
egy folytonosan változtatható neutrális szűrővel állítottam be a megfelelö értékre, melynek forgatásához egy léptetőmotort és egy hozzá tartozó házi készítésủ vezérlőt alkalmaztam.

\subsection{Kamera és állvány}

A képek rögzítéséhez egy Pixelink PL-B771F illetve egy PL-B741BF típusú kamerát (1280×1024 pixel, monokróm, Firewire, 0,1-1000 ms integrálási idő tartomány, maximum 27 fps) használtam. A felszínről közvetlenül visszaverődő fény kiszürése érdekében a kamera elé egy polarizátort helyeztem, melynek polarizációs irányát a lézerdiódából kilépő fény polarizációs irányára merőlegesen állítottam be. A háttérvilágítás - különösen 20 msnál hosszabb expozíciós idő esetén - lerontotta a kontrasztot. Ezt nagyrészt sikerült kiküszöbölni azzal, hogy a környezeti megvilágítás csökkentése mellett a kamera objektívjére egy olyan színszürőt is felszereltem, ami csak a $600 \mathrm{~nm}$ feletti hullámhosszakon átlátszó.

Az objektív apertúrájának, és ezáltal az interferenciafoltok méretének beállításához a következő módszert alkalmaztam: a tárgysíkban egy fehér papírt helyeztem a kamera elé és a blende különböző átméröinél meghatároztam a látótéren az 5×5-ös területeken számított lokális kontrasztok átlagát. A blende átmérőjét folyamatosan csökkentve azt a helyzetet választottam, amikor már nem nőtt tovább a kontraszt. A korábban leírtaknak megfelelően ekkor a foltok mérete valamivel meghaladta a pixelekét.

Arra is fény derült, hogy a rendszer rendkívül érzékeny a rezgésekre, ezért a kamerát és a megvilágító egységet egy megfelelően merev állványra rögzítettem, melyet egy rezgésmentes asztalon helyeztem el. Az elrendezésről készült fénykép a 23. ábrán látható. 


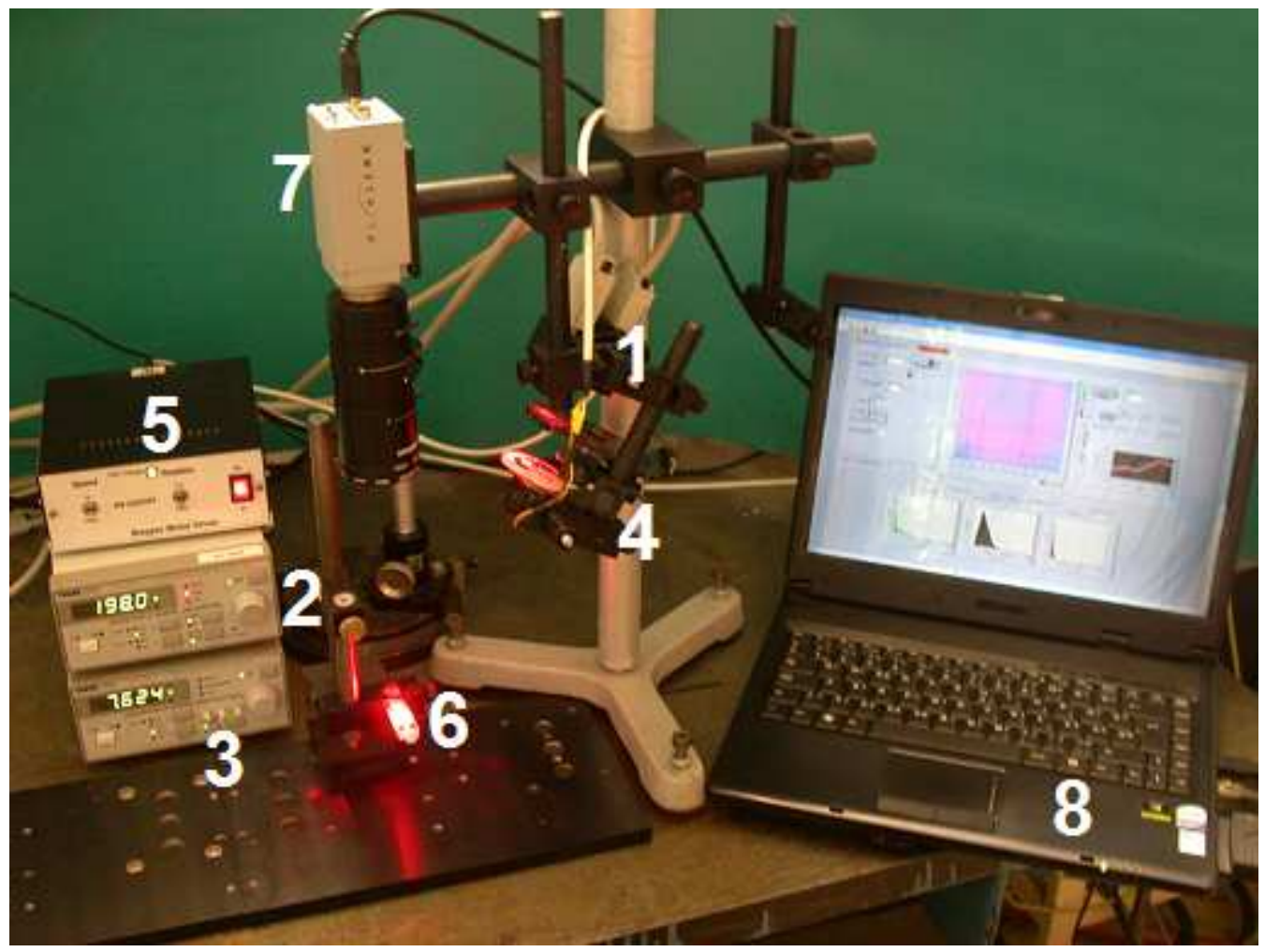

23. ábra. A kísérletek során használt mérési elrendezés. Balra a lézerdióda (1) meghajtását (2) és hömérsékletszabályozását (3) végzö tápegységek, valamint a szüröt (4) forgató léptetőmotor vezérlője (5), középen a vizsgált minta (6), a kamera (7), jobbra pedig a mérést vezérlő számítógép (8) látható.

\subsection{Képrögzítés és kiértékelés}

A képek rögzítését és kiértékelését egy-egy saját fejlesztésű, LabVIEW környezetben írt alkalmazással végeztem. Mivel a kutatás során az idő egy jelentős hányadát azzal töltöttem, hogy a mérés és a kiértékelés menetét könnyebbé, egyszerübbé és hatékonyabbá tegyem, így ebben a fejezetben csupán a mérések és eredmények megértéséhez szükséges információkat írom le, a szoftverfejlesztés részletesebb menetét a „9. A mérésekhez és az eredmények kiértékeléséhez használt szoftver kifejlesztése" fejezetben mutatom be.

A programozási feladatokat eleinte csak témavezetőm végezte, majd ezeket fokozatosan átvettem. Ahogy a program az idő előrehaladtával egyre újabb és újabb funkciókkal bővült, a szerkezetét többször át kellett alakítani, és a felhasználói felületet is újra kellett tervezni.

A program egy főmodulból és egy kontrasztelemző modulból állt. A főmodul feladata a mérés vezérlése volt,. A kontrasztelemző modul a főmodul által rögzített képeken a 
kontrasztelemzést végezte, valamint a kép fényességére illetve kontrasztjára vonatkozó statisztikákat készített. Bár ezen adatok nem elegendőek valós idejü megfigyelésekhez, a kezelő számára hasznos információkat hordozhatnak a rendszer beállításaival kapcsolatban.

A képek tárolására egy saját fájlformátumot definiáltam, amely tartalmazta a képadatokat és a kamera beállításait is (expozíciós idő, felbontás, gamma érték, erősítési tényező, színmélység és trigger típusa). A kontraszttérképek tárolására szintén saját fájlformátumot alkalmaztam, mely az előbb felsorolt paraméterek és a lebegőpontos kontrasztadatok mellett tartalmazta a kontrasztszámításhoz alkalmazott beállításokat (lokális kontraszt számításához használt ablak mérete és léptetése) is. 


\section{Szintetikus mintán elvégzett mérések. Több expozíciós idő alkalmazása.}

\subsection{A megfelelő minta megalkotása}

Első kísérleteim annak vizsgálatára irányultak, hogy a mintában található mozdulatlan szóró elemek milyen hatást gyakorolnak a kialakuló interferenciaképek kontrasztjára. A biológiai szövetek imitálására egy szintetikus modellt készítettem, melyben a vért valamilyen szuszpenzióval vagy emulzióval, a mozdulatlan szövetrészeket (pl. bőrfelszín) valamilyen jó fényszóró, ugyanakkor áttetsző anyaggal kívántam helyettesíteni [51].

Első lépésként egy, a kísérleti céloknak megfelelő szuszpenziót vagy emulziót kerestem. Először könnyen hozzáférhető, lehetőleg olcsó anyagokkal (montmorillonit, hintőpor, Teflon por és kovasav vizes szuszpenzióival, valamint tejjel) próbálkoztam, azonban huzamosabb ideig tartó mérésekre ezek nem voltak alkalmasak, mivel gyorsan (akár néhány perc alatt) leülepedtek, csak csekély mértékben szórták vissza a fényt, vagy éppen romlandóak voltak. Végül polisztirén (latex) mikrogömb szuszpenziót alkalmaztunk (Duke Scientific, $600 \mathrm{~nm}$ és $3 \mu \mathrm{m}$ átmérő), mely már alkalmasnak bizonyult kísérleteimhez. A minta sematikus képe a 24. ábrán látható. A szuszpenziót tartalmazó küvetta megvilágított oldalának egy részét átlátszatlan fehér papírral vontam be, ez a terület referenciaként szolgált. A területről rögzített interferenciaképnek, illetve az azok alapján számított kontraszttérképeknek időben állandóaknak kellett lenniük, esetleges megváltozásuk a rendszer rezgésére vagy a lézernyaláb instabilitására utalt. A megvilágított oldal egy másik részére különböző áttetsző szóró rétegeket - pauszpapírt, Teflon fóliát (Goodfellow, 50 és $100 \mu \mathrm{m}$ vastag) - ragasztottam, ez biztosította a statikus szórást. Ezen területek esetén a kamerába a szóró rétegről, illetve - mivel az áttetsző volt az alatta lévő szuszpenzióról is érkeztek fotonok, és ezek együtt alakították ki a szórási interferenciaképet. A küvetta megvilágított felületének fennmaradó részét szabadon hagytam, hogy tisztán meg lehessen figyelni a szuszpenziót is. 


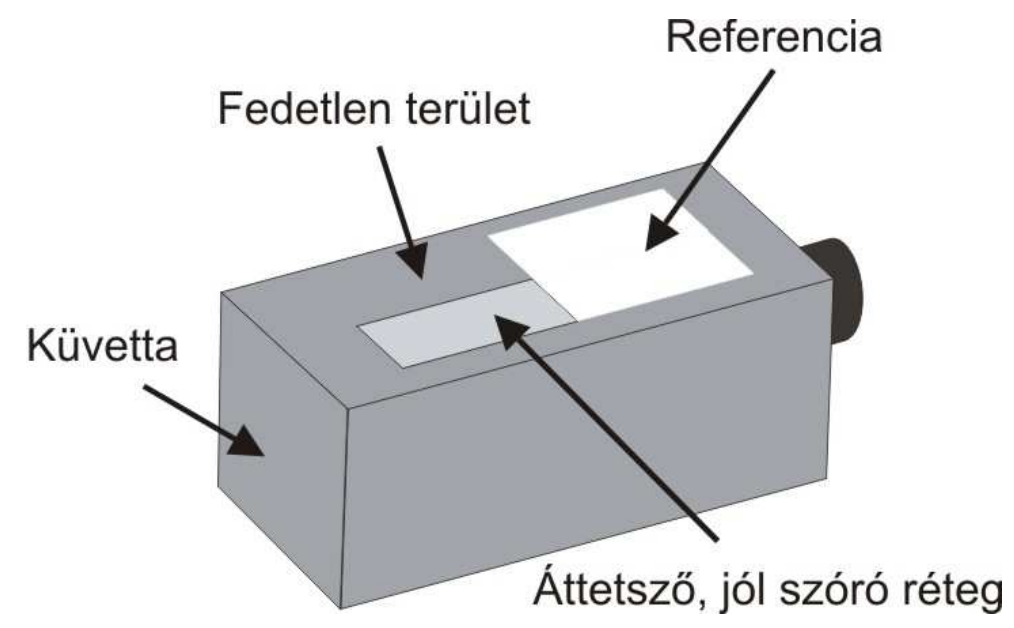

24. ábra. A modell minta sematikus ábrája.

\subsection{Mérések nyugvó szuszpenzión. Több expozíciós időtt alkalmazó modell} bevezetése.

650 nm átmérőjű mikrogömbökből készített, 2 V/V\% koncentrációjú szuszpenziót helyeztem egy $5 \mathrm{~mm}$ belső átméröjű küvettába, a vér perfúzióját a mikrogömbök jelentős Brown-mozgása imitálta. A mérések során 660 nm hullámhosszú lézerfénnyel világítottam meg a mintát. A mérések során 1, 2, 5, 10, 20, 50 és 100 ms-os expozíciós időkkel vettem fel 25-25 képet. Bár a kamera támogatta rövidebb és hosszabb expozíciós idők alkalmazását is, az előbbi túlságosan fényszegény képeket eredményezett volna (ami a kvantálási hiba miatt a kontrasztértékek torzulásához vezetett volna), az utóbbi esetén pedig túlságosan zavaróvá vált volna a háttérvilágítás. Sajnos a szűrő megfelelő pozícióba forgatása viszonylag sok időt (1-10 másodpercet) vett igénybe, ennek következtében az után, hogy a szűrő a megfelelő pozícióba került, az aktuális expozíciós idővel 20-30 képet készítettem. A minta megvilágított részének területe körülbelül $1 \mathrm{~cm}^{2}$ volt. A lokális kontrasztértékeket $5 \times 5$ pixelnyi ablakkal határoztam meg, melyet 3 pixelenként léptettem. Ennek eredményeként a lokális kontraszttérképek térbeli felbontása csaknem négyszeresére nőtt, ugyanakkor valamely terület átlagos kontrasztja nem változott meg jelentősen. Brown-mozgás során a részecskék sebessége normál eloszlású [52], azonban a „2. Elméleti áttekintés” c. fejezetben leírt praktikus okok miatt az áramlási sebesség meghatározása Lorentz-féle sebességeloszlást feltételezve lehetséges az (58) formula alapján. Szerencsére úgy tapasztaltam, hogy az utóbbi eloszlást feltételező formulákkal meghatározott görbék jól illeszkednek a Brown-mozgást végző részecskék esetén számított 
kontrasztértékekre is. A jelenség természetéből adódó statisztikai zaj miatt a kontrasztértékek az egyes expozíciós időknél nem állandóak. A statisztikai zaj csökkentése érdekében minden expozíciós idő esetén átlagoltam a rögzített 25 kép alapján meghatározott 25 kontrasztértéket. A 25. ábra a kontraszt függését ábrázolja a kamera integrációs idejétől. A mérések eredményei jól mutatták, hogy a $K(T)$ értékek jelentősen eltérnek az ideálistól: a kontraszt maximuma nem érte el az 1-et, és különböző fedőrétegek alkalmazása esetén minimális értéke meg sem közelítette a 0-t (25. ábra).

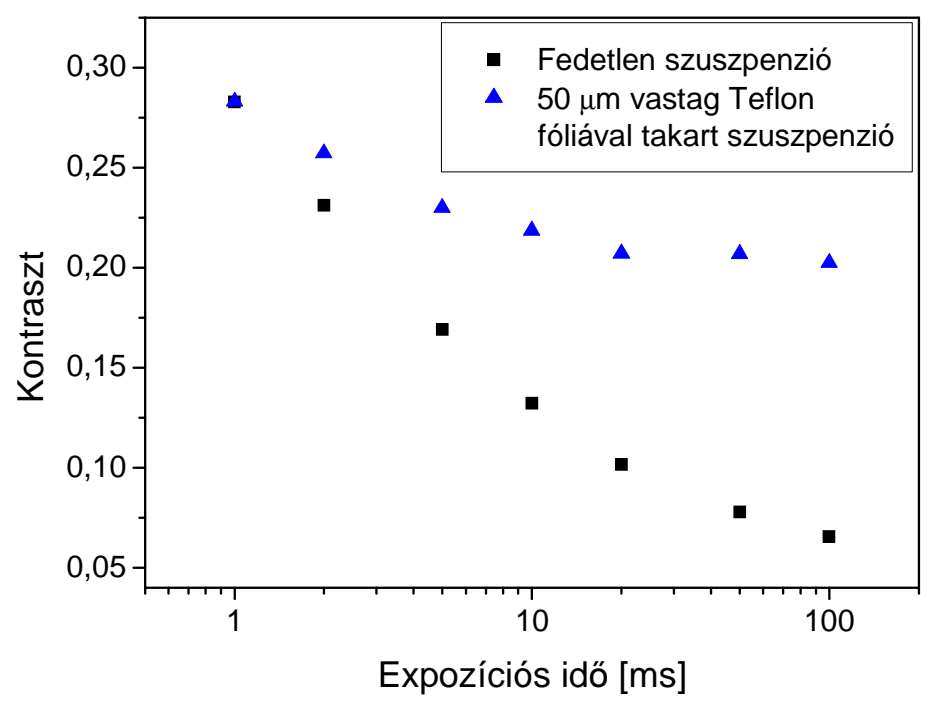

25. ábra. Különböző expozíciós időkkel rögzített képek alapján számított kontrasztértékek a küvetta fedetlen és $50 \mathrm{~mm}$ vastag Teflon fóliával fedett terïletén. Jól látható, hogy a statikus szórás hatására a kontraszt minimumértéke jelentösen eltolódik.

A problémára a következő megoldásához a következő gondolatmenet útján jutottam el. Ha feltesszük, hogy a mozgó és álló elemek által létrehozott szórási interferenciakép független egymástól, akkor

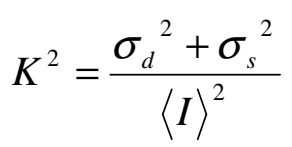

adódik, ahol $\sigma_{d}^{2}$ a mozgó elemek által, míg $\sigma_{s}^{2}$ a mozdulatlan elemek által létrehozott szórási interferenciakép intenzitásértékeinek varianciája. Ennek megfelelően a kontrasztgörbék előállíthatóak egy, az expozíciós időtől függő, illetve egy attól független 
(esetünkben konstans) görbe súlyozott összegeként. Ha a kontrasztértékek esetén a mozgó és az álló elemek hozzájárulását a $P_{1}$ és $P_{2}$ paraméterekkel jellemezzük, akkor az (54) összefüggést a következő alakra hozhatjuk:

$$
K^{2}(T)=P_{1}^{2} \frac{1}{T} \int_{0}^{T} c^{2}(t) d t+P_{2}^{2}
$$

Ennek megfelelően $\lim _{T \rightarrow 0} K^{2}(T)=P_{1}^{2}+P_{2}^{2} \quad$ és $\quad \lim _{T \rightarrow \infty} K^{2}(T)=P_{2}^{2}$. A paraméterek alkalmazásával az (55) formula a

$$
K^{2}(T)=P_{1}^{2} \frac{\tau}{2 T}\left[1-\exp \left(\frac{-2 T}{\tau}\right)\right]+P_{2}^{2},
$$

az (57) formula pedig a

$$
K^{2}(T)=P_{1}^{2} \frac{\tau^{2}}{2 T^{2}}\left[\exp \left(\frac{-2 T}{\tau}\right)-1+\frac{2 T}{\tau}\right]+P_{2}^{2}
$$

alakot ölti. Más alapokról indulva, de hasonló eredményre jutottak Parthasarathy és munkatársai is [24], azonban az általuk javasolt formula lényegesen nehezebben kezelhető függvényillesztések során. A (74) összefüggés segítségével görbét illesztettem a kontrasztértékek átlagaira, melynek eredménye a 26. ábrán látható. 


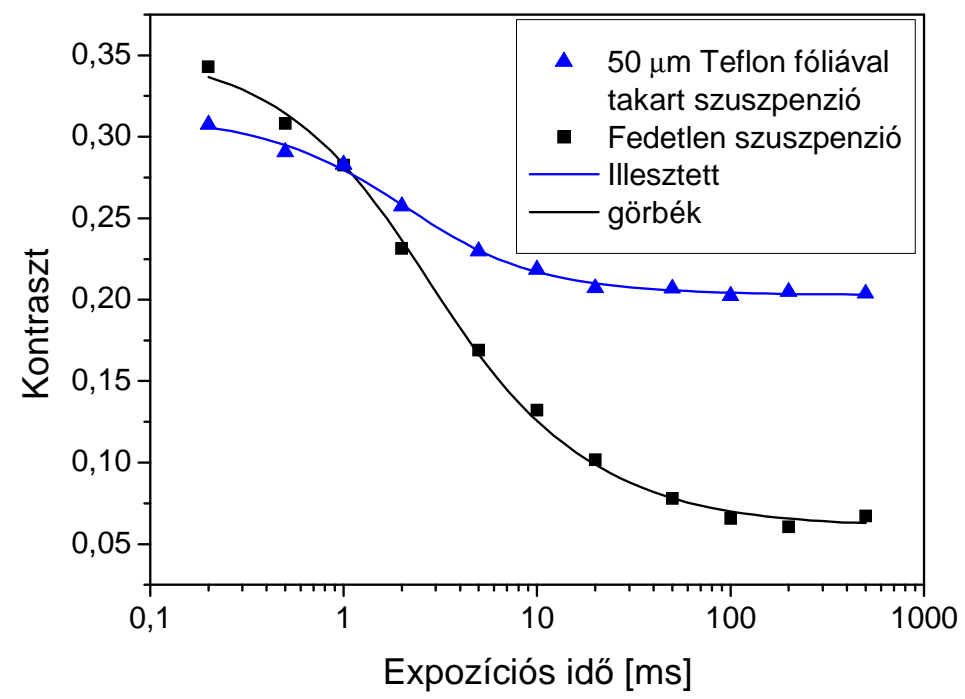

26. ábra. A kontraszt függése az expozíciós időtöl fedetlen és 2 réteg pauszpapírral fedett szuszpenzió esetén. A görbék illesztése a (74) formula alapján történt. A görbék jobb láthatósága érdekében az ábra elkészítéséhez 0,2 és 500 ms között változtattam az expozíciós idöt.

Az 1. táblázatról leolvasható, hogy a szóró réteggel takart és a fedetlen szuszpenzión meghatározott korrelációs idők a több expozíciós időt alkalmazó módszer esetében 10\%-os hibahatáron belül megegyeztek egymással, ezzel szemben a hagyományos és a $\beta$ korrekciót alkalmazó, egy expozíciós időt felhasználó méréseknél kapott értékek jelentősen eltérnek egymástól [53]. Az egy expozíciós időt alkalmazó mérésekhez 2 ms-os expozíciós időt választottam, mivel - ahogy a 26. ábrán is látszik - ez volt a legközelebb a görbe inflexiós pontjához. Az 1. táblázatban látható, hogy a szóró réteg vastagodásával együtt a számított korrelációs idő is kismértékben megnőtt. Ennek egyik oka az, hogy az (57), (58) és (74) formulák csak akkor adnak helyes eredményt, ha a fényérzékeny chipen keletkező mintázat két, egymástól statisztikailag teljesen független mintázat szuperpozíciója. Esetünkben viszont a szuszpenzióból a kamera felé szóródó fény áthaladt a szóró rétegen. Mivel a Teflon szórási együtthatója több mint 1200 1/cm [54], így a szuszpenzióról és a szóró rétegről szóródó fény által létrehozott két mintázat már nem tekinthető teljesen függetlennek, hiszen az előbbit részben eltéríti a szóró réteg. Szerencsére, ahogy a dolgozat későbbi részeiben részletezett, élő mintákon elvégzett mérésekből kitünik, ez nem befolyásolja számottevően a relatív változások leírását. 


\begin{tabular}{|c|c|c|c|}
\hline & \multicolumn{3}{|c|}{$\frac{\tau}{\tau_{\text {fedetlen }}}$} \\
\hline & $\begin{array}{c}\text { Több } \\
\text { expozíciós }\end{array}$ & $\begin{array}{c}\beta \text {-korrigált } \\
(2 \mathrm{~ms})\end{array}$ & $\begin{array}{l}\text { Klasszikus } \\
\quad(2 \mathrm{~ms})\end{array}$ \\
\hline $\begin{array}{c}\text { Fedetlen } \\
\text { szuszpenzió }\end{array}$ & 1 & 1 & 1 \\
\hline $50 \mu \mathrm{m}$ Teflon & 1,06 & 1,35 & 1,31 \\
\hline $100 \mu \mathrm{m}$ Teflon & 1,09 & 3,61 & 2,54 \\
\hline Pauszpapír & 1,07 & 3,05 & 2,49 \\
\hline
\end{tabular}

\section{1. táblázat. A korrelációs idők relatív függése az alkalmazott szóróréteg függvényében}

A probléma feltárására Bandyopadhyay és munkatársai [36], valamint Parthyasay és munkatársai [55] is javaslatot tettek, azonban valós, élő minták esetén egyikük eredményei sem csökkentették a korrelációs idő eltolódását jelentős mértékben. A dolgozat megírásának időpontján egy számítógépes szimuláció megírásán dolgoztam, amely a szakirodalomban fellelhető általánosan alkalmazott módszerektől [56] eltérő elven volt képes szórási interferencia képeket előállítani. Bár a szimulációval nyert első eredmények bíztatóak, azonban a dolgozat megírásakor még nem állt rendelkezésre elegendő eredmény azok közzétételéhez.

\subsection{Mérések áramló szuszpenzión}

A szuszpenziót áramoltató kísérletek során a mérési elrendezés a mintatartót leszámítva a korábbiakhoz hasonló volt. A kísérlethez $3 \mu \mathrm{m}$ átmérőjű mikrogömbökből készítettem 2 V/V\% koncentrációjú szuszpenziót. A gömbök nagyobb átmérője kevésbé intenzív Brownmozgást eredményezett, ami így nem volt jelentős hatással az áramlásmérés eredményeire. A mintatartó ez esetben egy simára polírozott plexitömb volt, melyen több helyen, különböző átmérőjű furatok haladtak keresztuil: a szuszpenziót ezeken keresztül átáramoltatva végezhettem a méréseket. A szuszpenzió egy, a plexitömbhöz képest fél méter magasan elhelyezett tartályból egy, a plexitömb alatt lévő edénybe folyt, áramlási sebességét egy infúzióhoz használatos csepegtetővel szabályoztam. A mérések során 50 $\mu \mathrm{m}$ vastag Teflon fóliával takartam le a mintatartó furatok feletti területének egy részét. Egy teljes, több expozíciós időt magába foglaló képsorozat felvétele akár 1 percet is igénybe vehetett, ami ugyan vetekedhet egy pásztázó Doppler-rendszer sebességével, 
azonban valós idejü megfigyelésekhez túl hosszú idő. Ezért egy új mérési protokollt dolgoztam ki: egy kezdeti, (az előző fejezetben ismertetett) több expozíciós időt is felhasználó, nyugalomban levő szuszpenzión végzett mérés során meghatároztam az egyes területekre jellemző $P_{1}$ és $P_{2}$ paraméterek értékeit, majd ezeket konstansnak feltételezve egyetlen expozíciós idővel kapott kontrasztértékek segítségével határoztam meg a korrelációs időt különböző áramlási sebességek mellett. Ez utóbbi expozíciós időt úgy választottam meg, hogy közel legyen a $K(T)$ görbe inflexiós pontjához, hiszen ekkor voltak a legjobban követhetőek a változások: a 26. ábra alapján 1 és 2 ms-os értékeket választottam. Minden mérés során 25 képet készítettem 1 vagy 2 ms-os expozíciós időt alkalmazva. Sajnos nem volt lehetőség egy mérés során mindkét expozíciós idő használatára, így minden mérés során különbözött az áramlási sebesség. A mérések eredményei a 27. ábrán láthatóak. Jól látható, hogy mind a fedetlen, mind pedig a Teflon fóliával takart területen mért reciprok korrelációs idő $(1 / \tau)$ lineárisan függ az áramlási sebességtől.

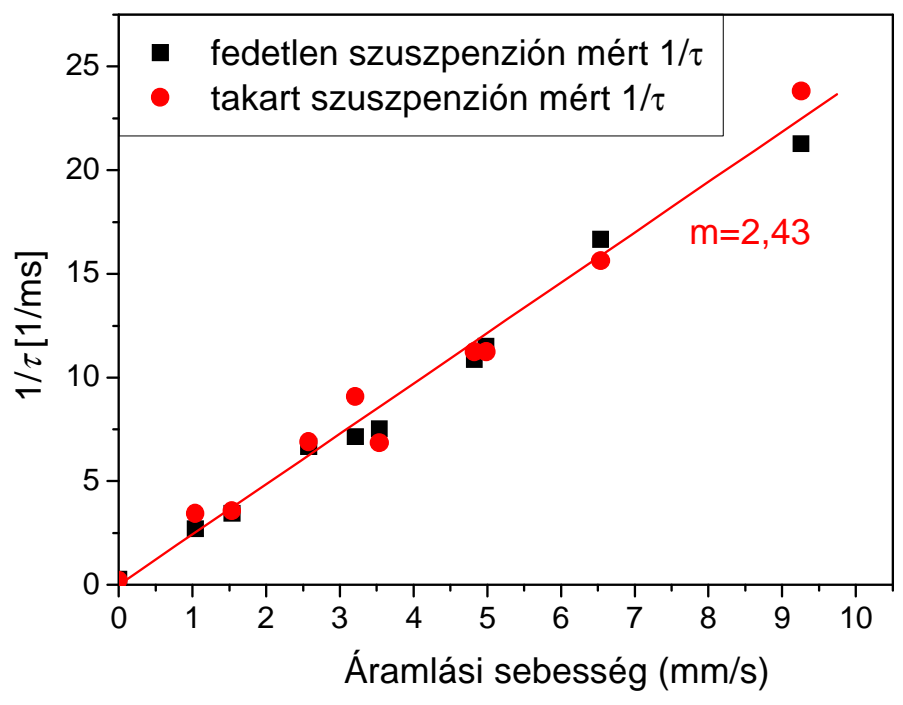

27. ábra. A fedetlen és $50 \mu m$ Teflon fóliával takart szuszpenzión mért korrelációs idők reciprokjai az áramlási sebesség függvényében

A két különböző szórási tulajdonsággal rendelkező területen mért korrelációs időket egymással összehasonlítva jól látható, hogy a mérések során előforduló két nagyságrendnyi tartományon ezek jól egyeznek egymással (28. ábra). 


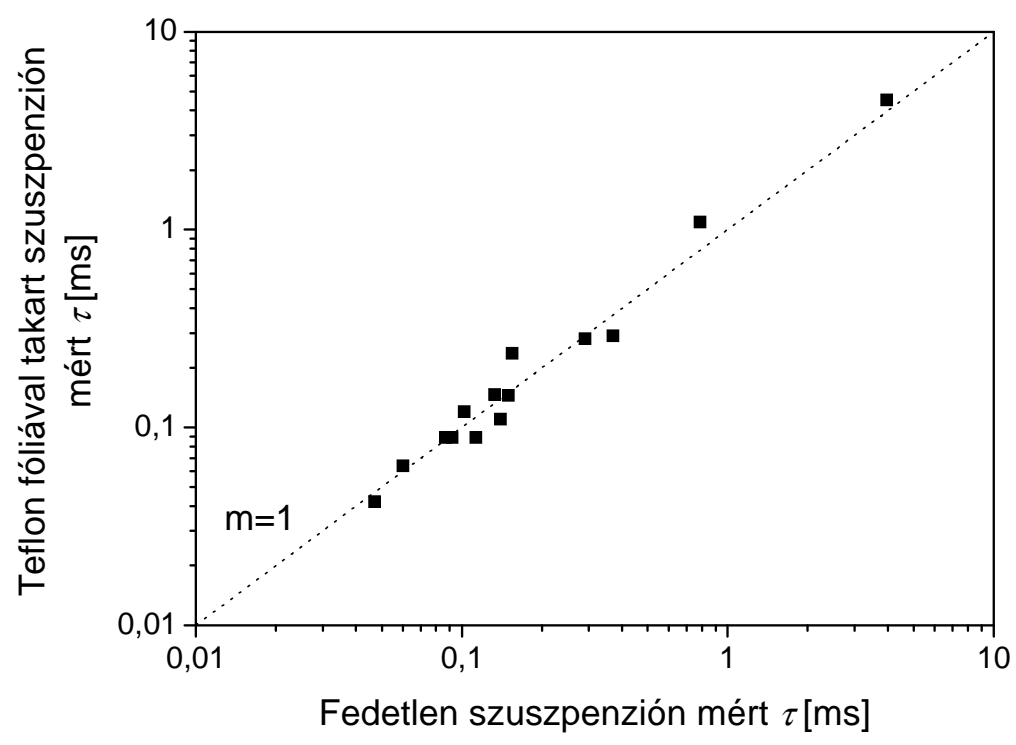

28. ábra. Az 50 um vastag Teflon fóliával takart és a fedetlen szuszpenzión mért korrelációs idők. Az m=1 meredekségü egyenes az eredmények jobb áttekinthetöségéért lett berajzolva.

Ebből arra a következtetésre jutottam, hogy valós mérések esetén a $P_{1}$ és $P_{2}$ kezdeti meghatározása után elegendő lehet egyetlen expozíciós idő felhasználásával képeket rögzíteni, ami lehetővé tenné a bőrfelszín, vagy más statikus szórással rendelkező szövet valós idejü megfigyelését.

Ugyanezt a mérési sorozatot kiértékeltem hagyományos, egyetlen expozíciós időn alapuló módszerrel is az (57) összefüggést alkalmazva, ennek eredményét láthatjuk a 29. ábrán. Bár a fedetlen szuszpenzión meghatározott korrelációs idő értékek ekkor is közelítőleg egyenes arányban változnak az áramlási sebességgel, a fedőréteggel takart szuszpenzió ettől teljesen eltérő eredményeket ad, amelyeket ráadásul befolyásol az alkalmazott expozíciós idő értéke is. Mindez az általam kidolgozott mérési eljárás létjogosultságát igazolja [51]. 


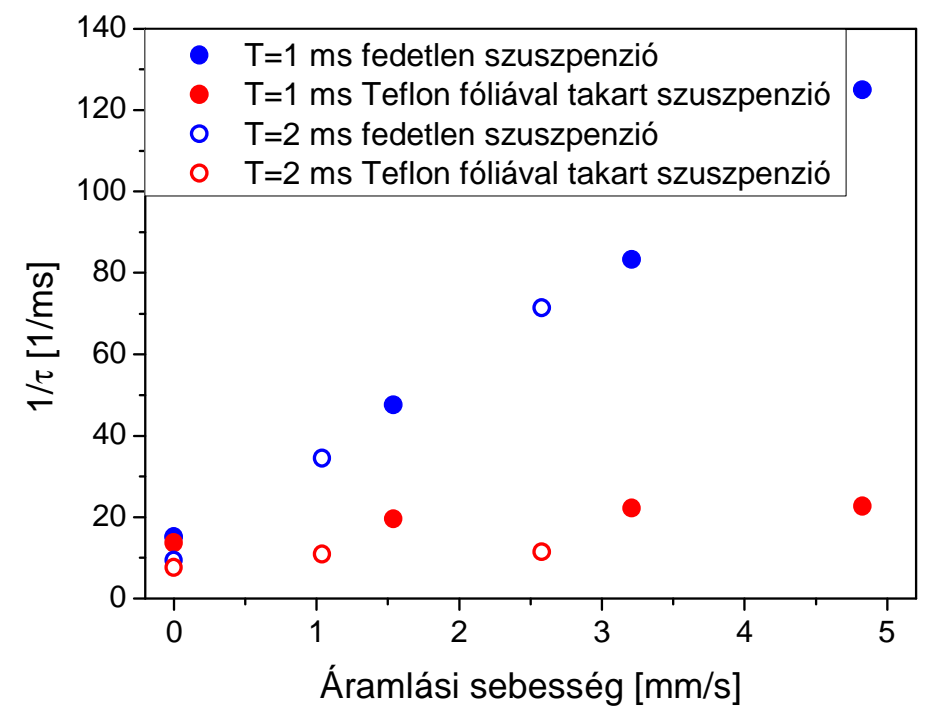

29. ábra. Egyetlen expozíciós időt felhasználó módszerrel meghatározott korrelációs idők különféle áramlási sebességek és $T=1$ ms illetve $T=2 \mathrm{~ms}$ expozíciós idő esetén. Jól látható, hogy a módszer hibás eredményt ad szóró réteg jelenlétében. 


\section{Mérések agyfelszínen}

\subsection{Kísérleti elrendezés és mérések}

A továbbiakban az SZTE Élettani Intézet munkatársaival együttmüködésben malacok agyfelszínén is teszteltem a több expozíciós időt magába foglaló mérési módszert. Megvizsgáltam, milyen mértékben térnek el az általa és a $\beta$-korrekciót alkalmazó, valamint a hagyományos, egyetlen expozíciós időt felhasználó módszer által adott eredmények egymástól, mennyire lehet indokolt a nyilvánvalóan bonyolultabb mérés alkalmazása hasonló körülmények között. A kísérleti alanyok 1 naposak voltak, és tömegük 2,5 és 3,5 kg között változott. A mesterséges kómában levő állatok agykérgét egy, a koponyán elhelyezett körülbelül $11 \mathrm{~mm}$ átmérőjü ablakon keresztül lehetett vizsgálni. Ahhoz, hogy különböző vérellátottsági állapotokban tudjak mérni, a malacokat különböző stimulusoknak tették ki, melyek a következők voltak:

a) 5 és $10 \%$ koncentrációjú $\mathrm{CO}_{2}$ gázt tartalmazó levegő belégzése,

b) 2,1\% koncentrációjú $\mathrm{H}_{2}$ gázt tartalmazó levegő belégzése,

c) agy felszínre juttatott, 1 és $10 \mu \mathrm{mol}$ bradykinint tartalmazó mesterséges agygerincvelői folyadék,

d) agy felszínre juttatott, 100 mmol NMDA tartalmú mesterséges agy-gerincvelői folyadék.

Az NMDA és a bradykinin két, különböző hatásmechanizmusú lokálisan ható értágító vegyület. A magas $\mathrm{CO}_{2}$ koncentrációjú belégzett levegő hatására pedig intenzívebbé válik az agyszövet vérellátása és kitágulnak az erek. Az alacsony koncentrációban belégzett $\mathrm{H}_{2}$ élettani hatása egyelőre nem teljesen tisztázott.

A mérések a következőképpen folytak: először nyugalmi állapotban a korábban is alkalmazott expozíciós időkkel (1-100 ms) rögzítettem egy képsorozatot, majd valamelyik stimulus alkalmazása során a gyorsabb változások nyomon követése érdekében 2 ms-os expozíciós idővel folyamatosan, másodpercenként 4 interferenciaképet rögzítettem. A perfúzió stabilizálása után újból egy teljes, több expozíciós időt magába foglaló sorozatot vettem fel. A stimulus megszüntetésekor és a stabil állapot beállása után is hasonlóan jártam el. Ezután kis szünetet tartva a procedúrát ugyanígy ismételtük meg a többi stimulus esetében is. 


\subsection{Mérési eredmények}

Dolgozatomnak nem célja a stimulusok élettani hatásainak elemzése, ezért kizárólag az egy és több expozíciós időt felhasználó mérési módszerekkel kapott mérési eredményeket vetem össze. A képek kiértékelése során a parenhima (látható ereket nem tartalmazó agyszövet) vérellátását, valamint az arteriolákban (vékonyabb artériákban) áramló vér sebességét vizsgáltam a különböző hatások során. A 30. ábrán két kijelölt terület látható az egyik malac esetén.

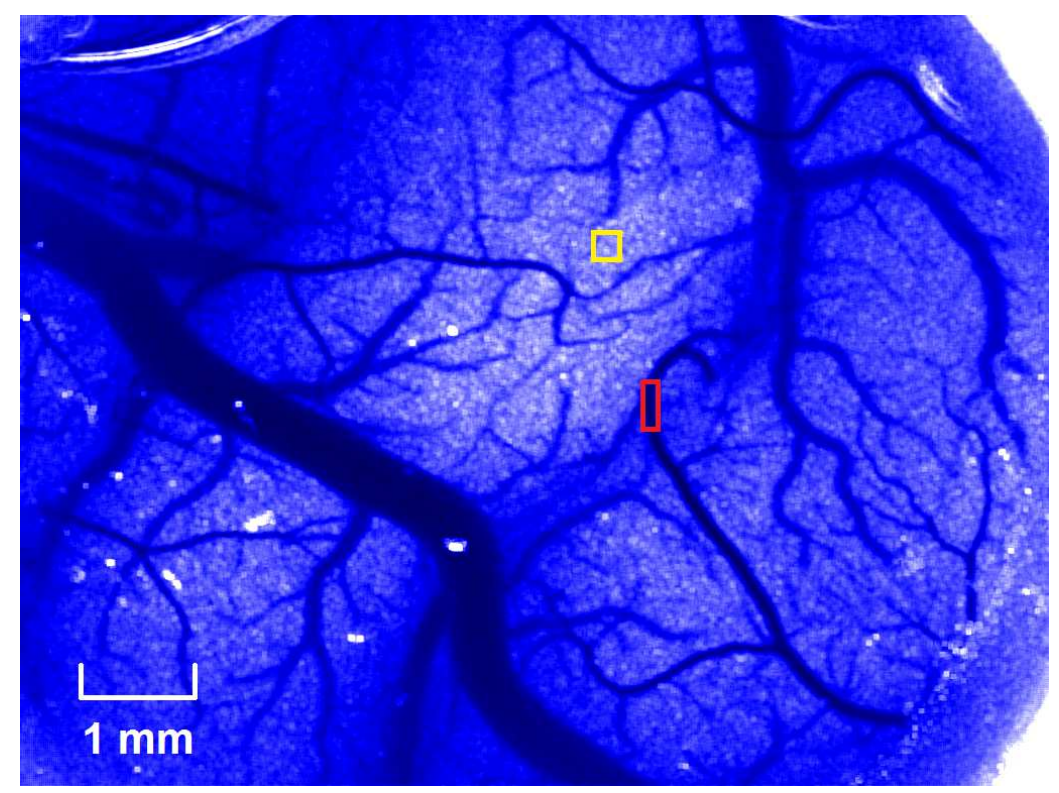

30. ábra. A vizsgált területek az agyfelszínröl készült kontraszttérképen: sárga-

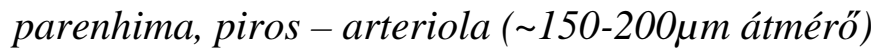

A 31. ábra az egy expozíciós időt alkalmazó mérések eredményeit (reciprok korrelációs idő) veti össze a több expozíciós mérésekével. Jól látható, hogy amíg 2 ms-os expozíciós idő esetén a mért reciprok korrelációs idők jó összhangban vannak, addig $20 \mathrm{~ms}$ esetén a $\beta$-korrekciót alkalmazó módszer alulbecsüli az áramlási sebességet, ráadásul intenzív áramlás esetén (a bekarikázott területen) telítést is mutat. 


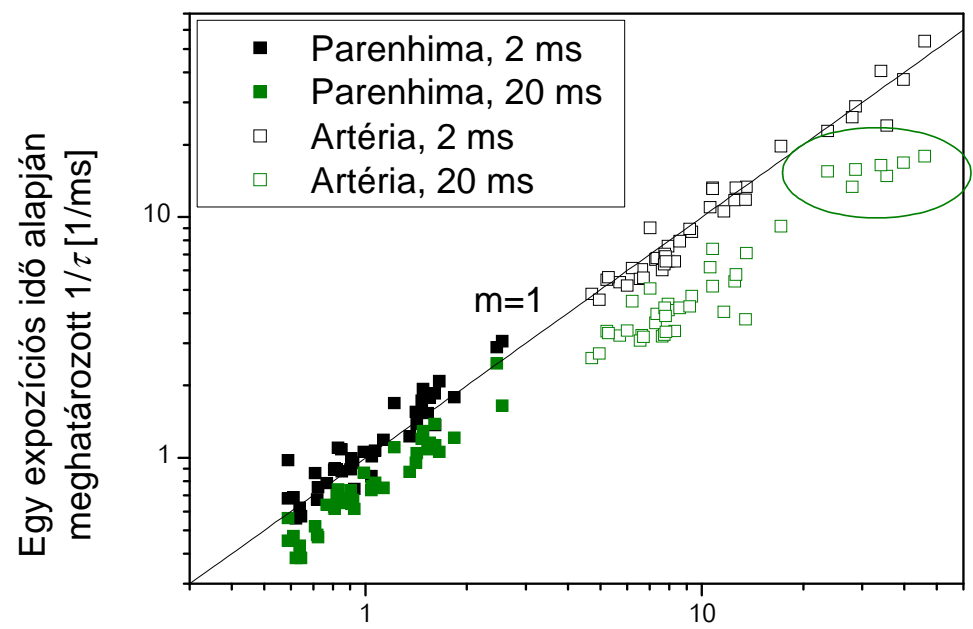

Több expozíciós idővel meghatározott $1 / \tau[1 / \mathrm{ms}]$

31. ábra. A 2 és 20 ms-os expozíciós időt alkalmazó mérések eredményei a több expozíciós időt alkalmazók eredményeinek függvényében. A 20 ms-os expozíciós időt felhasználó mérés alulbecsüli az áramlási sebességet, sőt nagyobb sebességeknél telítést is mutat (karikázott terület), míg a rövidebb expozíciós idő alkalmazásával ezek a hibák kiküszöbölhetök

Mivel a gyakorlatban nem az abszolút reciprok korrelációs időkkel, hanem azoknak egy kezdeti értékhez viszonyított változásával számolnak, ezt is összehasonlítottam a különböző kiértékelési módszerekre úgy, hogy az egyes expozíciós idők és szövettípusok esetén meghatároztam a relatív eredményekre illeszthető egyenesek meredekségét (2. táblázat).

\begin{tabular}{|c|c|c|}
\hline & $2 \mathrm{~ms}$ & $20 \mathrm{~ms}$ \\
\hline Parenhima & 1,09 & 1,04 \\
\hline Artéria & 1,05 & 0,93 \\
\hline
\end{tabular}

2. táblázat. Az egy expozíciós időt alkalmazó mérések által a több expozíciós időt felhasználó módszerhez képest mutatott relatív változások

Ebből jól látható, hogy a 2 ms-os mérések 9 és 5\%-kal túlbecsülik az áramlást a parenhima és az artéria esetén, a 20 ms-os mérés pedig a parenhimára 4\%-kal túlbecsült eredményt ad, viszont az artéria esetén 7\%-kal alacsonyabb értékeket mutat a több expozíciós időt felhasználó méréshez képest, mindemellett telítést mutat intenzívebb áramlás esetén. 
A mérések alapján megállapítható, hogy az agyfelszínen történő vizsgálatok során a szövet vérellátása és az erekben áramló vér áramlási sebessége kellő pontossággal meghatározható a $\beta$ korrekciós faktor és egyetlen, 1-5 ms-os expozíciós idő alkalmazásával, ami szükségtelenné teszi a jóval bonyolultabb, több expozíció időt magába foglaló mérések használatát. Figyelemre méltó azonban, hogy a kísérleti illetve kereskedelmi forgalomban is hozzáférhető összeállítások többségében alkalmazott, 10 msnál hosszabb expozíciós idő az erek esetén hamis eredményt adhat [57].

Ezeket a méréseket korábban egy, a bőr esetén alkalmazottal azonos lézer Dopplerrendszerrel (ld. „7. Börszövet vérellátásának vizsgálata”, de természetesen másmilyen szondákkal) lehetett kivitelezni. A szondák végeit ekkor vagy a koponyán elhelyezett ablakon, vagy a koponyán fúrt lyukakon keresztül juttatták el az agyfelszíntől hozzávetőleg $1 \mathrm{~mm}$ távolságra. Mivel az agyfelszín kismértékben elmozdult a különféle stimulusok során, a lézer Doppler-rendszer sok esetben torzított eredményt szolgáltatott. Torzulást okozhatott az is, hogy nem minden esetben volt egyértelmü, hogy a szondák végei a parenhima vagy egy ér felett vannak-e. Méréseimből egyértelmüen kitünik, hogy az agyfelszín vérellátásának megfigyelése esetén a LASCA lényegesen megbízhatóbb eredményeket tud nyújtani, mint egy hagyományos lézer Doppler-rendszer. 


\section{Bőrszövet vérellátásának vizsgálata}

\subsection{Kísérleti elrendezés és mérések}

A bőr vérellátásának vizsgálatára alkalmazott LASCA eljárások során jellemzően az (57) vagy (58) formula alapján határozzák meg a perfúzió mértékét, így a különböző személyeken, vagy egyetlen személyen, de eltérő körülmények között készült mérési eredmények a korábbiakban leírt okok miatt csak korlátozottan hasonlíthatók össze. A modellkísérleteim eredményei szerint az általam kidolgozott több expozíciós időt alkalmazó módszer jól használható intenzív statikus szórással rendelkező minták áramlásváltozásainak nyomon követésére, azonban a gyakorlati alkalmazhatóságot csak valódi, megfelelő referenciával alátámasztott bőrszöveti mérésekkel lehet igazolni. A kísérletekhez használt elrendezés vázlata a 32. ábrán látható. Az összeállítás hasonló a korábbi fejezetekben használtakhoz, azonban a rendszert referenciaként kiegészítettem egy 635 nm hullámhosszú lézerfényt alkalmazó kétcsatornás kontakt Doppler-rendszerrel (Periflux 4000), amellyel lehetővé vált a szöveti perfúzió megfelelő pontosságú, valós idejü mérése. A LASCA vizsgálathoz 808 nm-es hullámhosszú, 200 mW maximális teljesítményü lézerdiódát alkalmaztam. A megvilágított szövet területe hozzávetőleg $1 \mathrm{~cm}^{2}$ volt. Minden mérés 5 sorozatból állt, ezek mindegyikének rögzítése során 1, 2, 5, 10, 20, 50 és 100 ms-os expozíciós időkkel vettem fel 25-25 képet. Abbot és munkatársai megmutatták, hogy vörös és infravörös fény esetén egy Doppler-rendszer ugyanazt az eredményt adja fehér bőrü páciensek esetén [58]. Ez alapján feltételeztük, hogy az általunk alkalmazott két rendszer által alkalmazott fény hullámhosszbeli eltérése nem változtat az eredmények összehasonlíthatóságán. 


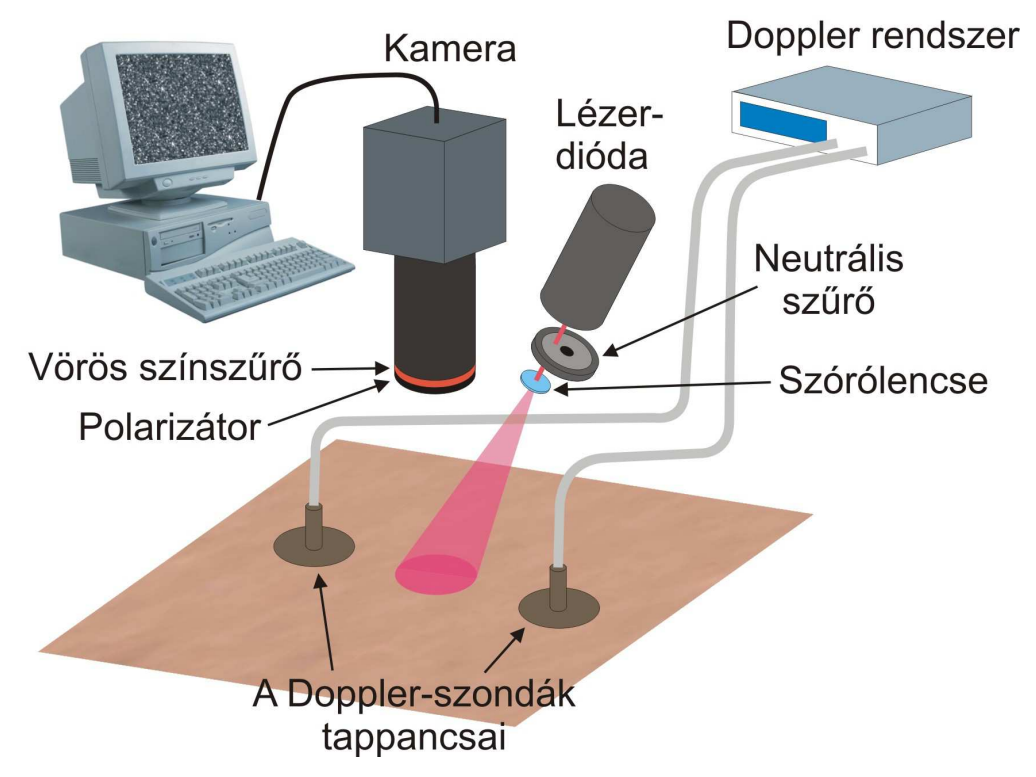

32. ábra. A bőr vérellátását vizsgáló összeállitás vázlata

A referenciamérés optimális módja az lett volna, ha ugyanazon terület szimultán mérését megvalósíthattam volna a speckle és a Doppler rendszerrel, azonban ez csak egy számomra hozzáférhetetlen pásztázó vagy kamerás Doppler készülékkel lett volna lehetséges. Az általam használt Doppler-rendszer szondái hozzávetőleg $1 \mathrm{~mm}^{3}$ térfogatban képesek a véráramlást figyelni, rendkívül érzékenyek a mozgatásra, a mérés során nem távolíthattam el őket, így azokat a speckle rendszerrel vizsgált terület közelében rögzítettem úgy, hogy a lehető legkisebb távolságra legyenek attól. Az eszköz három mennyiség: a CMBC (Concentration of Moving Red Blood Cells, a Doppler-spektrum nulladik momentuma, a térfogatban mozgó vörös vértestek számával és ezáltal sűrűségével függ össze), a PU (Perfusion Unit, a Doppler-spektrum első momentuma) és a Velocity (a CMBC és a PU hányadosa, a térfogatban mozgó vörös vértestek átlagos sebességével arányos) mérését tette lehetővé. Úgy tapasztaltam, hogy a speckle rendszer által mért $1 / \tau$ értékek a PU-tal változtak arányosan, így ezekre a mennyiségekre a továbbiakban SCPU (Speckle Contrast Perfusion Unit) és LDPU (Laser Doppler Perfusion Unit) néven fogok hivatkozni. A méréseket az alkar bőrfelületén végeztem, minden esetben olyan területet választottam ki a mérésekhez, amelyet a nagyobb látható erek elkerültek.

A felvételek kiértékelése során három módszer alkalmazhatóságát hasonlítottam össze:

i) Hagyományos egy expozíciós időt alkalmazó mérés (az (57) formula alapján), ennek során 10 ms-os expozíciós idővel történt a képek rögzítése. 
ii) Egy expozíciós időt alkalmazó mérés $\beta$-korrekcióval (az (58) formula alapján), ekkor szintén 10 ms-os expozíciós időt alkalmaztam. Újabban a kereskedelemben kapható LASCA készülékek ezt a kiértékelési módszert alkalmazzák. Ezen rendszereket minden mérés előtt úgy kalibrálják, hogy egy fehér papírt vagy Teflontömböt helyeznek a mintatartóra, és az ezen meghatározott kontraszt értékére állítják be $\beta$-t.

iii) Az általam kidolgozott több expozíciós időt felhasználó mérés és a (74) formulát felhasználó függvényillesztés.

Minden méréssorozat 3 részből állt:

Először nyugalmi állapotban végeztem egy mérést, majd egy vérnyomásmérő mandzsettáját az alany felkarjára helyezve a szisztolés nyomásnál 30-35 Hgmm-rel magasabb nyomást létrehozva jelentősen lelassítottam a véráramlást az alkarban (okklúzió). Miután a Doppler-rendszer által mutatott áramlási sebesség állandósult, újabb mérést végeztem. Végül megszüntettem az elszorítást (reperfúzió), és az alkar vérellátásának stabilizálódása után elvégeztem a harmadik mérést is. Nyolc személyen összesen 20 teljes mérést végeztem, azonban ezek egy része használhatatlannak bizonyult. Azok a mérések kerültek kizárásra, amelyek során egymásnak ellentmondó eredményeket, azaz a vérellátás intenzitásának ellentétes irányú változását jelezte a két rendszer. Ennek oka lehetett a speckle rendszerrel vizsgált terület és a Doppler-szondák távolsága, az egyes területek eltérő reakciója az okklúzióra és a reperfúzióra, vagy nem látható nagyobb erek jelenléte, illetve az okklúzió során esetlegesen bekövetkezett különösen intenzív tremor (a mozgásszervek természetes, enyhe remegése).

\subsection{Mérési eredmények}

A Doppler- és a speckle rendszer által mért eredmények igen erősen változtak alanyról alanyra, illetve akkor is, amikor egy alany esetén egymástól nem túl messze lévő területeket vizsgáltam, ezért a tényleges értékek helyett relatív értékekkel dolgoztam úgy, hogy minden mérés során a nyugalmi állapotban meghatározott értéket 100\%-nak feleltettem meg, és az elszorított illetve ismét felengedett állapotban számított értékeket ehhez viszonyítottam. A relatív változás nyomon követése általánosan alkalmazott módszer a klinikai vizsgálatok és az orvosi célú kutatások esetében is.

A 33. ábra az i), ii) és iii) módszerrel végzett függvényillesztéseket mutatja egy mérési adatsor esetén úgy, hogy az $i$ ) és ii) módszerrel a 10 ms-os expozíciós idővel rögzített képeken számított kontrasztértékekre illesztettem. 


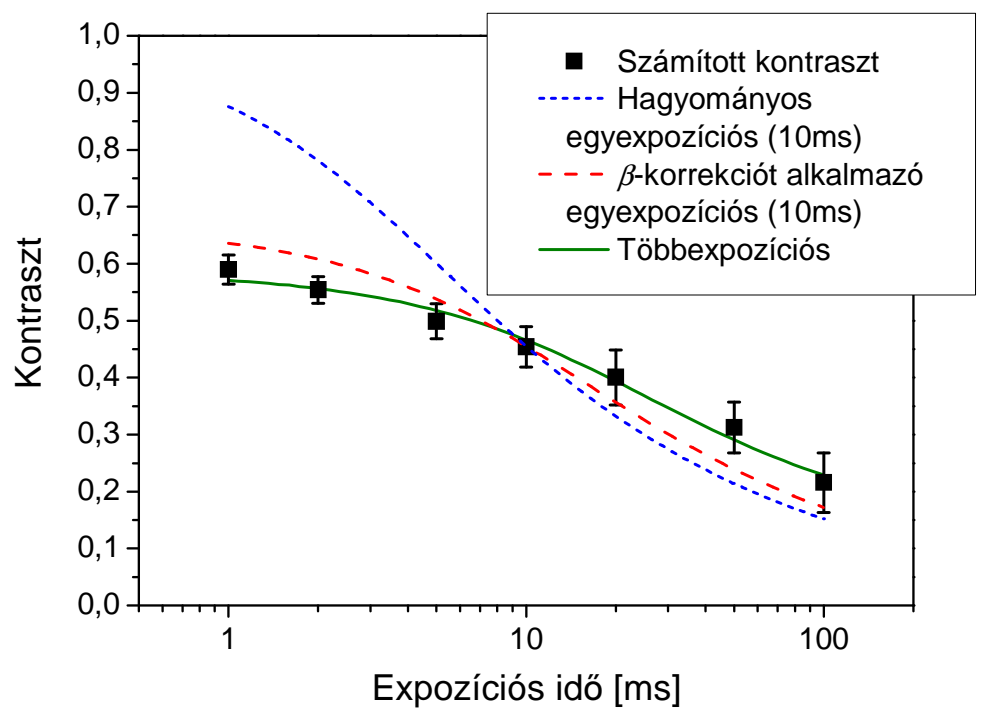

33. ábra. Az i), ii) és iii) módszerrel valós adatsorra illesztett görbék. Jól látható, hogy csak a több expozíciós időt alkalmazó módszerrel lehet a mérés bizonytalanságán belül illeszteni

Az egyes expozíciós időkhöz tartozó kontrasztértékek a vizsgált hozzávetőleg $2 \times 2$ mmes területen számított lokális kontrasztértékek átlagolásával lettek meghatározva. A kontrasztértékek szórása egyrészt a szórási interferenciakép és a lokális kontrasztértékek természetes fluktuációjának, másrészt a bőrfelület véletlenszerủ mozgásának is köszönhető. Jól látható, hogy a hagyományos, egyetlen expozíciós időt felhasználó kiértékelés mennyire félrevezető lehet: a 10 ms-os expozíciós időt kivéve (hiszen erre történt az illesztés) jelentősen eltér az illesztett görbe lefutása a valós mérési pontoktól. A $\beta$-korrekciót alkalmazó módszer jobb illeszkedést biztosít, azonban csak a több expozíciós időt felhasználó módszer képes a mérés bizonytalanságán belül görbét illeszteni a mérési pontokra.

A 34. ábra az i), ii) és iii) módszerrel meghatározott relatív áramlási sebesség értékeket mutatja a Doppler rendnszer által mért relatív perfúziós egység függvényében. Az áttekinthetőség javításáért mindegyik ábrán szerepel az m=1 meredekségủ egyenes. 

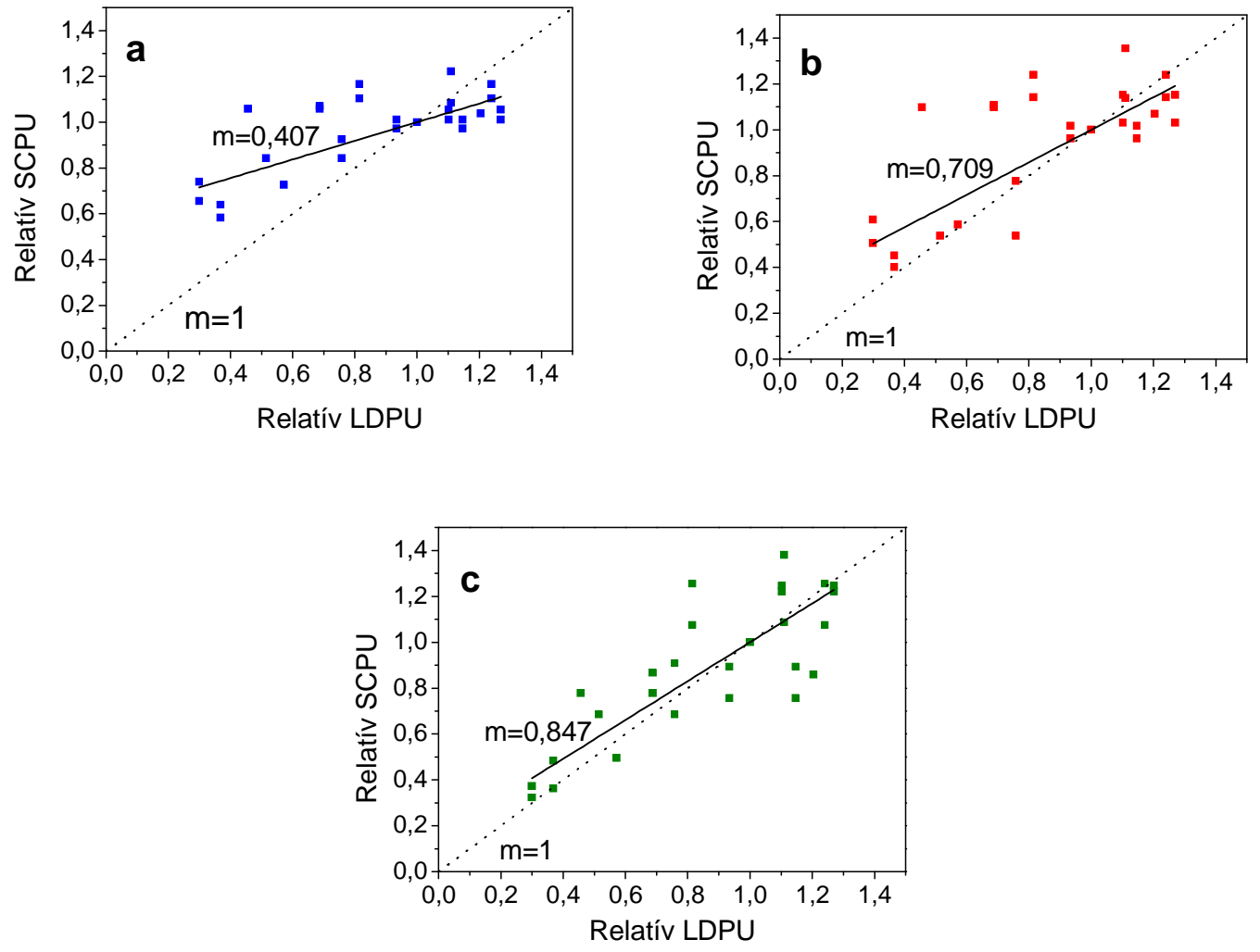

34. ábra. A hagyományos egy expozíciós időt (a), a $\beta$-korrigált egy expozíciós időt (b) és a több expozíciós időt (c) alkalmazó módszer által számított relatív perfúziós értékek a Doppler rendszer által mért adatok függvényében.

A nagy szórás legföképp annak köszönhető, hogy a Doppler-szondák a speckle rendszer által megvilágított területtől több cm távolságra voltak elhelyezve. Ennek ellenére világosan látszik, hogy bár mindhárom módszer az elszorításkor felül-, míg a reperfúzió során alulbecsüli a Doppler rendszer által mutatott relatív változást, ezen eltérések mértéke nagyban függ az alkalmazott kiértékelési módszertől. Ez a tendencia nagyon erősen jellemző a hagyományos egy expozíciós időt alkalmazó módszerre (34. a ábra). Jobb eredményt adott a $\beta$-korrekciót is alkalmazó egy expozíciós időt használó módszer (34. $b$ ábra), azonban a Doppler-rendszer által mért relatív értékekkel a legjobb egyezést a több expozíciós időt felhasználó mérés eredményei mutatták (34. c ábra).

A 35. ábra azt mutatja, hogy az egyes speckle módszerek által mért perfúzió változás átlagosan mennyire volt összhangban a Doppler-redszer által mért változásokkal, valamint leolvasható az egyes értékek szórása is. Ez a grafikon is jól mutatja, hogy a több expozíciós időt alkalmazó módszer lényegesen megbízhatóbb eredményeket ad a többinél: 
az általa mutatott változások átlagosan csupán közel 15\%-kal térnek el a Doppler-rendszer által mértektől.

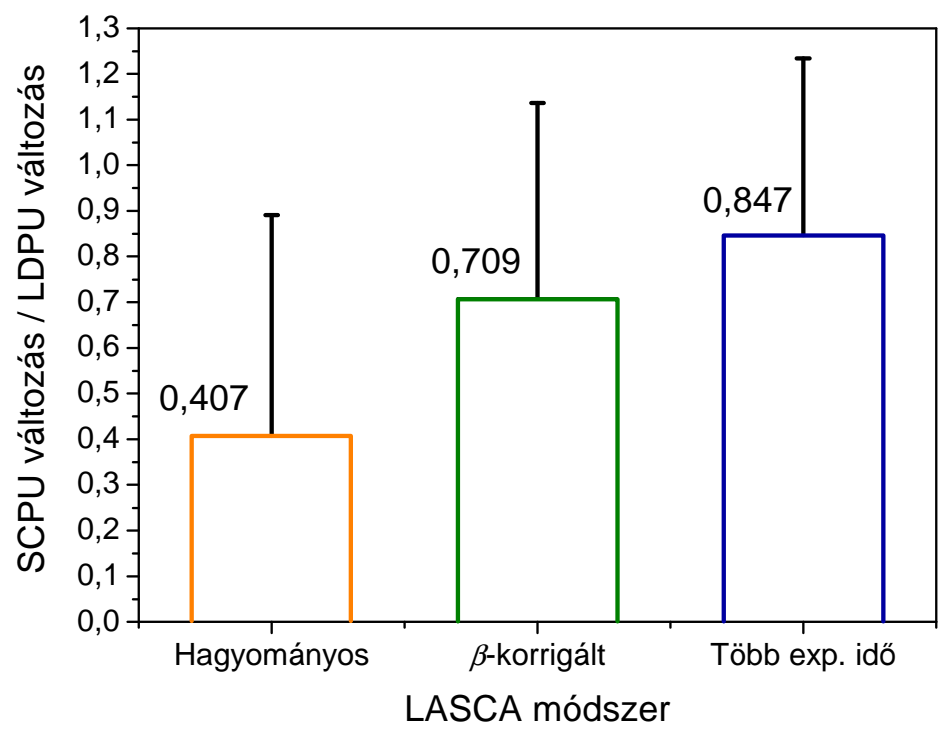

35. ábra. A speckle módszerek által a Doppler rendszerhez képest a különféle stimulusok esetén mutatott változások nagysága

Megvizsgáltam azt is, hogy a modellkísérletek eredményeihez hasonlóan egy kezdeti, több expozíciós időt magába foglaló mérés során a $P_{1}$ és $P_{2}$ paraméter értékét meghatározva kalibrálható-e a rendszer úgy, hogy utána egyetlen expozíciós időt felhasználva folyamatosan mérni lehessen a szövet vérellátását. A 36. ábrán a különféle stimulusok során az áramlás stabilizálódása után felvett kontrasztgörbék láthatóak. Szembetűnő, hogy az egyes görbék esetén nem állandóak a rövid expozíciós időre vonatkozó $\lim _{T \rightarrow 0} K(T)=\sqrt{P_{1}^{2}+P_{2}^{2}} \quad$ és a hosszú expozíciós időre vonatkozó $\lim _{T \rightarrow \infty} K(T)=\sqrt{P_{2}^{2}}$ kontrasztértékek, és ezzel együtt a $P_{1}$ és $P_{2}$ paraméterek értéke nem állandó. Feltételezhetően ez annak köszönhető, hogy a stimulusok során a szövet általában megduzzad, megváltozik a vér koncentrációja és ezáltal az interferenciakép kialakulásához hozzájáruló dinamikus és statikus rész aránya. Sajnos ez lehetetlenné teszi az „,5.3 Mérések áramló szuszpenzión” c. fejezetben említett kombinált, kalibrációt is alkalmazó protokoll alkalmazását. Emellett nyilvánvalóvá vált, hogy $\beta$-korrekciós módszer nagyobb hibája részben annak köszönhető, hogy a kalibrálás során papír vagy Teflon tömb esetén 
meghatározott $\beta=\lim _{T \rightarrow 0} K(T)$ kontraszt nem azonos a szöveti $\lim _{T \rightarrow 0} K(T)$ kontraszttal, ami még ráadásul a perfúzió pillanatnyi mértékétől is függést mutat [59].

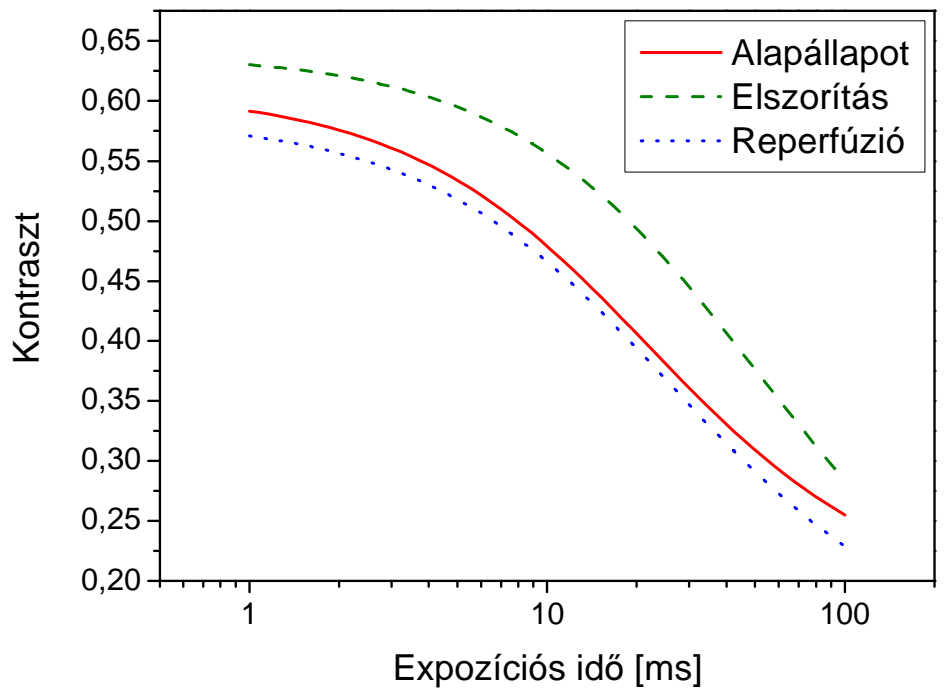

36. ábra. A különböző stimulusok során felvett kontrasztértékekre illesztett kontrasztgörbék. A görbék tendenciája jól mutatja, hogy a $P_{1}$ és $P_{2}$ paraméterek a három görbe esetén számottevö mértékben eltérnek egymástól 


\section{Az időbeli felbontás javítását célzó fejlesztések}

Ahogy azt a „2. Elméleti áttekintés” c. fejezetben kifejtettem, a szórási interferenciakép intenzitás-eloszlása teljesen véletlenszerü, a lokális kontrasztértékek pedig kisszámú (jellemzően $5 \times 5$ vagy $7 \times 7$ ) pixel alapján kerülnek meghatározásra. Mivel az elrendezés általában úgy van beállítva, hogy az interferenciafoltok átméröje nagyjából megegyezzen a pixelek átmérőjével, a lokális kontrasztértékek jelentős zajjal terheltek: a jel-zaj arány (singnal-to-noise ratio, SNR) jellemzően 4 vagy annál alacsonyabb. Ugyanebben a fejezetben szerepel az SNR javításának egyik legegyszerübb módja, a kontrasztértékek (vagy kontraszttérképek pixelenkénti) átlagolása. A mérések időbeli felbontását jelentősen rontotta az, hogy az átlagolást minden expozíciós idő esetén számos (20-25) kép figyelembevételével kellett elvégezni.

\subsection{A fényerő szabályozása}

A fejlesztés első lépéseként lehetővé kellett tenni, hogy az expozíciós időt és a hozzá tartozó fényerőt képről képre lehessen változtatni. A forgatható neutrális szürő pozícionálása meglehetősen sok időt (3-20 másodperc) vett igénybe, így más módszert kellett keresni. A legkézenfekvőbb megoldás egy elektrooptikai vagy akusztooptikai modulátor [24] beiktatása lett volna, azonban ezen eszközök sajnos nem álltak a rendelkezésünkre. A fényerőt először a lézerdiódán átfolyó áram erősségével kívántam beállítani, azonban ez az interferenciaképeken jól látható módusugrásokat eredményezett. nagy pontossággal meghatározhattam A lézerdióda müködési hullámhosszának áram és hőmérsékletfüggését egy Avantes AvaSpec 2048 típusú spektrográffal (vonalszélesség: körülbelül $0,5 \mathrm{~nm} 811,5 \mathrm{~nm}$ körül, saját mérés alapján) térképeztem fel, melynek eredménye a 37. ábrán látható. Ez alapján nyilvánvaló volt, hogy nincs olyan müködési tartomány, ahol ez a módszer alkalmazható. 


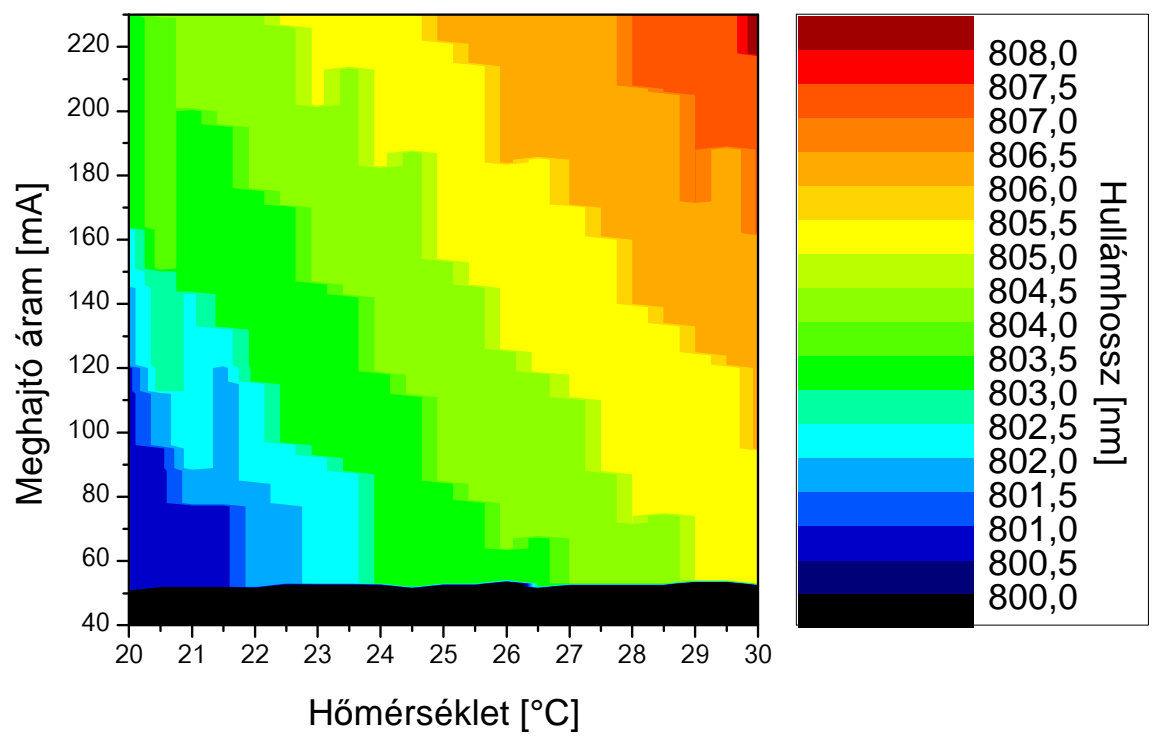

37. ábra. A 808 nm-es lézerdióda fényének hullámhossza a diódafoglalat hömérsékletének és a rajta átfolyó áram erősségének függvényében.

Végül egy, a területen még nem használt megoldást dolgoztam ki: a lézer áramának kapcsolóüzemű szabályozását. Ennek során minden expozíció adott számú, adott hosszúságú felvillanást tartalmazott, és az egyes expozíciós idők hosszát a felvillanások között eltelt idő szabta meg (38. ábra). Mivel a felvillanások során a meghajtó áram erőssége azonos volt, a kamera által érzékelt fény átlagos intenzitása jó egyezést mutatott minden expozíció során.

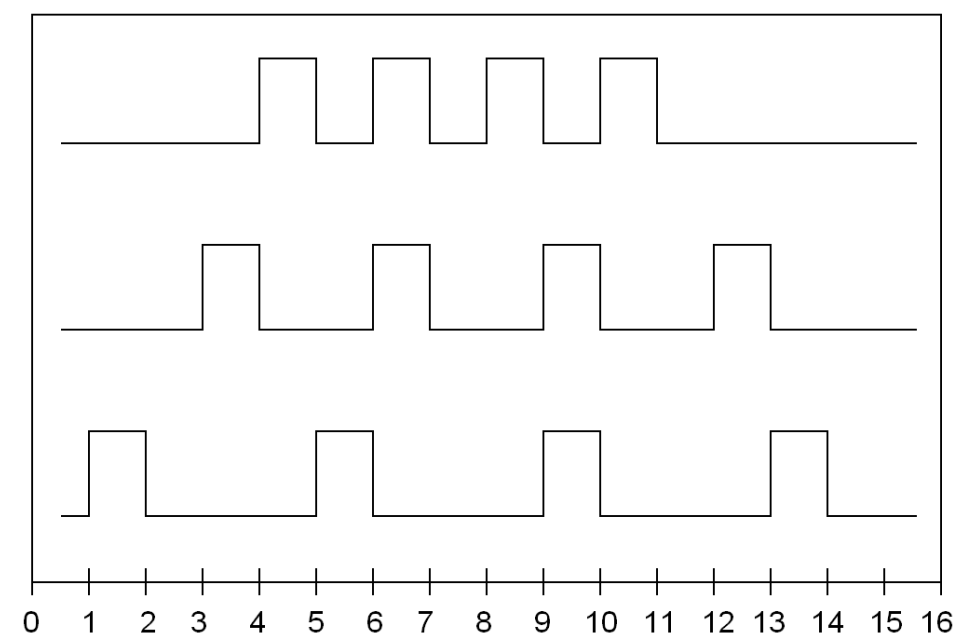


38. ábra. 8, 12 és 16 időegység hosszú expozíciós idők elöállitásához szükséges vezérlőjelek sematikus idödiagramja.

Ezáltal a kamera integrációs ideje állandó értéken, jellemzően a mérés során alkalmazott leghosszabb expozíciós idő hosszán volt tartható, ami tovább csökkentette a mérés során fellépő zavaró tényezőket. A megvalósításhoz nélkülözhetetlen volt a mérő és elemző programok teljes áttervezése, valamint egy házi készítésű vezérlőegység, amely elindította az integrációt és vezérelte a megvilágítást. Ezek részletes leírását a „9. A mérésekhez és az eredmények kiértékeléséhez használt szoftver kifejlesztése” c. fejezetben találhatja az Olvasó.

A folytonos megvilágításhoz hasonlóan a lézerdióda kapcsolóüzemü vezérlése esetén is nagymértékben befolyásolja annak hőmérséklete a keletkező interferenciaképet. Mivel azonban a lézerdióda meghajtó árama modulálva van, annak hőmérsékletét nem csupán a rajta áthaladó áram erőssége befolyásolja, hanem a moduláció kitöltési tényezője is. Bár a módszer elve rendkívül egyszerü, az a mérések során csak számos paraméter gondos beállítása esetén alkalmazható, melyek a következőek:

- a felvillanások során beállított maximális áramerősség

- a lézerdióda meghajtóáramát szabályozó egység reakcióideje

- a felvillanások hossza

- a lézerdiódán átfolyó áram erőssége a felvillanások között

- a lézerdiódát tartalmazó foglalat hőmérséklete

Mivel az általam alkalmazott legrövidebb expozíciós idő értéke $1 \mathrm{~ms}$ volt, így annak több felvillanásra történő felosztása azt eredményezte, hogy a felvillanások hossza csupán néhány tíz $\mu$ s volt. A rendszerünkbe épített hőmérsékletstabilizált foglalat sajnos nem volt alkalmas a hirtelen hőmérséklet ugrások kezelésére, így a lézerdióda hőmérsékletét az egyes felvillanások elején és végén jelentősen meghatározta azok hossza. Ennek köszönhetően a lézerdióda által kisugárzott fény hullámhossza erős függést mutatott a fentebb felsorolt paraméterektől. A szintetikus mintán (Teflon tömbön, valamint fedetlen és Teflon fóliával takart szuszpenzión) elvégzett kalibrációs méréseim során feladatom az volt, hogy úgy állítsam be e paraméterek értékeit, hogy az eredmény megfeleljen a következő követelményeknek:

- a lézerdióda által kisugárzott fény spektruma maradjon állandó az expozíciós idők széles skáláján 
- egy mozdulatlan minta (Teflon tömb) valamely területe alapján számított kontraszt értéke legyen állandó az expozíciós idők széles skáláján

- fedetlen, valamint Teflon fóliával takart szuszpenzió esetén az egyes expozíciós idők alkalmazásakor számított kontrasztértékek mutassanak egymáshoz képest hasonló arányokat, mint folytonos megvilágítás esetén

- áramló szuszpenzió esetén a folytonos megvilágításhoz hasonlóan változzon a korrelációs idő az áramlási sebesség változtatásakor

A folytonos és a kapcsolóüzemü vezérlés esetén mérhető spektrumokat mutatja be a 39. ábra. Az utóbbi esetén megfigyelhető egy mellékcsúcs is, amit valószínűleg valamilyen tranziens folyamat okoz.
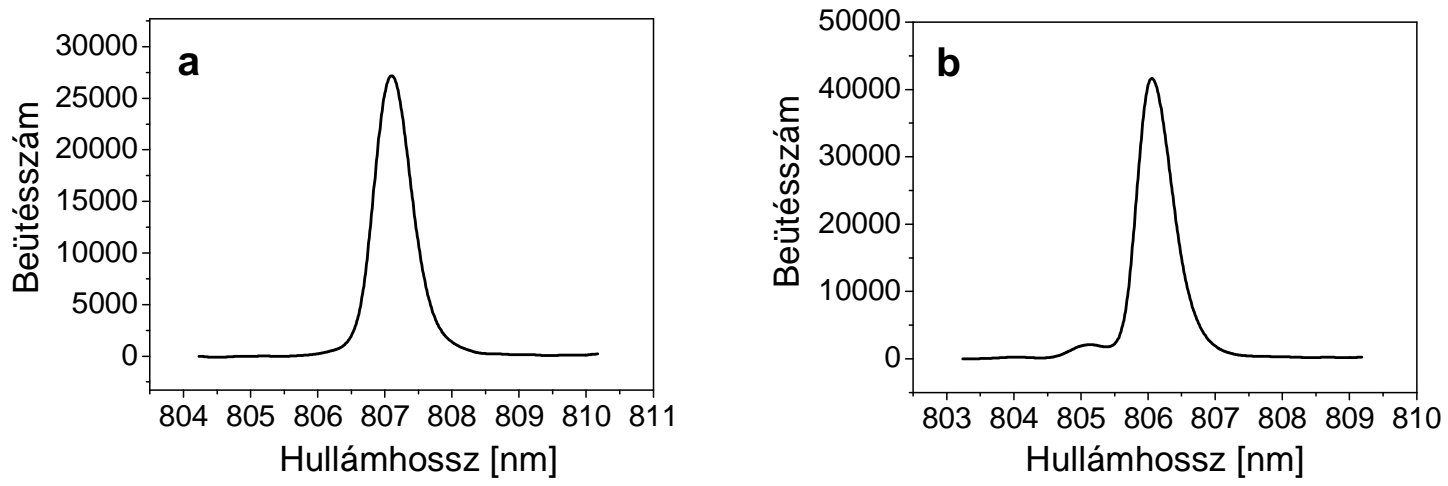

39. ábra. A lézerdióda fényének spektruma folytonos (a) és kapcsolóüzemü (b) vezérlés esetén. Figyelemre méltó a (b) ábrán a mellékcsúcs 805 nm-nél, amit valószínüleg az okoz, hogy a lézerdióda hömérséklete csak korlátozottan tud stabilizálódni a felvillanások során.

Egy digitális oszcilloszkóp (LeCroy LT364) segítségével elvégzett mérés során fény derült arra, hogy a mikrovezérlőt tartalmazó áramkör négyszögjel alakú gerjesztésre adott válasza körülbelül $2 \mu$ s hosszú fel- és lefutási idővel rendelkezik, míg a lézerdiódát meghajtó tápegység válasza körülbelül $10 \mu$ s hosszú fel- és lefutási idővel rendelkezik (40. ábra). Ez utóbbi jelentősen korlátozza a felvillanások számát, mivel egy 20 s hosszúságú (félértékszélességü) felvillanás esetén annak hosszából több mint $10 \mu$ s-nyit elvesz a lézerdiódán átfolyó áram fel- és lefutása [60], mely a spektrumban megfigyelt mellékcsúcs kialakulásáért is felelős lehet.

A mérések során a foglalat hőmérsékletét, a felvillanások maximális áramerősségét, valamint a felvillanások számát és hosszát széles tartományon változtattam. A több napon 
át tartó méréssorozat során megállapítottam, hogy a legnagyobb stabilitás a következő paraméterek esetén érhető el:

- felvillanások során alkalmazott áramerősség: 220 mA

- felvillanások között alkalmazott áramerősség: 40 mA (az a maximális áramerősség, amelynél még nem jelentkezik lézerműködés; valamelyest „előfüti” a lézerdiódát)

- felvillanások száma: 10

- felvillanások (vezérlőjelének) hossza: $47 \mu \mathrm{s}$

- legrövidebb és leghosszabb expozíciós idő hossza: 1 és 100 ms

- a foglalatban található termisztor ellenállásának értéke: $6,321 \mathrm{k} \Omega$ (körülbelül $37^{\circ} \mathrm{C}$ )

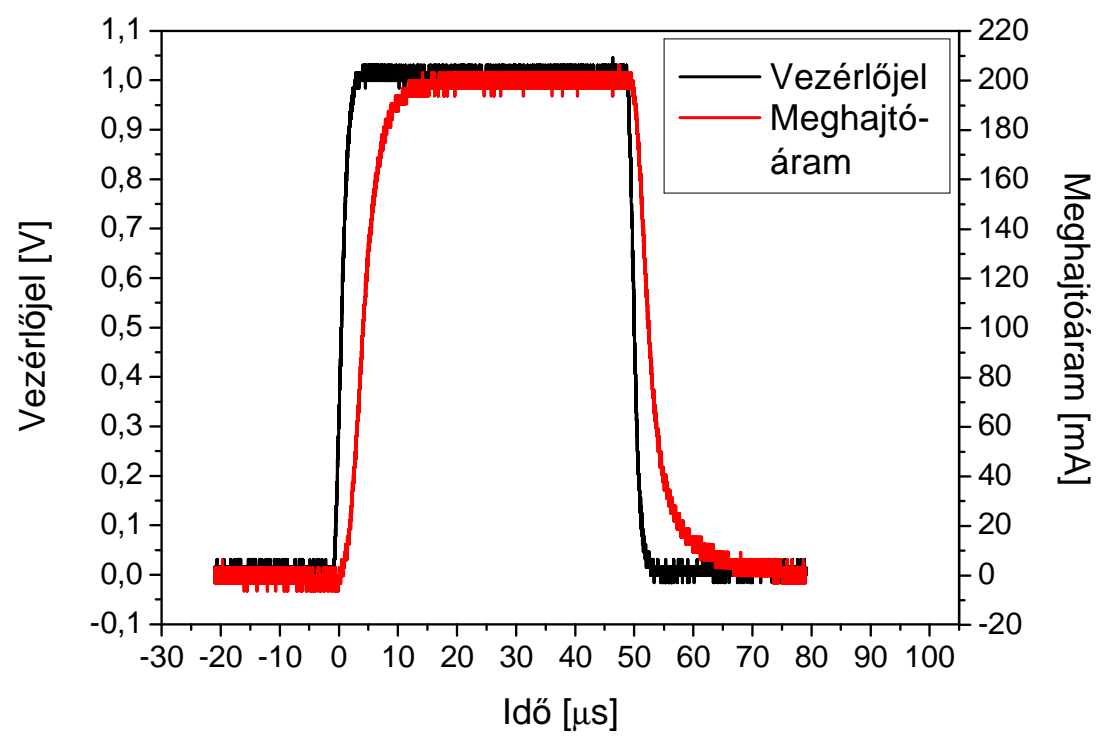

40. ábra. A felvillanást vezérlö jel feszültsége és a lézerdióda meghajtóárama egy felvillanás során. Jól látható a lézerdióda áramának a késése.

Ezen beállítások alkalmazásával a rendszer hozzávetőleg 2 órán át volt képes stabil müködésre. A stabilitást sikerült tovább növelnem úgy, hogy a felvillanások közötti áramerőséget $1 \mathrm{~ms}$ hosszú expozíciós idő esetén 0 mA-re állítottam, míg hosszabb expozíciós idők esetén fokozatosan növeltem $40 \mathrm{~mA}$-ig. Erre azért volt szükség, mert $1 \mathrm{~ms}$ hosszú expozíciós idő esetén a felvillanások között olyan rövid idő telt el, hogy a lézerdiódának nem volt ideje lehủlni, és az általa kisugárzott fény spektruma és a lokális kontraszt véletlenszerüen változott. A korrekció segítségével azonban a lézerdióda által 
disszipált hő mennyisége egyenletesebben oszlott el az egyes expozíciós idők esetén. Így a rendszer már több mint 4 órán keresztül képessé vált a stabil müködésre.

\section{2. Új mintavételezési eljárás bevezetése}

A fejlesztés második lépéseként egy, a területen eddig nem alkalmazott mintavételezési eljárást dolgoztam ki, melynek alapját az „,5.3. Mérések áramló szuszpenzión” c. fejezetben leírt protokoll képezi. Az eljárás lényege a következő:

- A mérés kezdetén egy hagyományos, több expozíciós időt alkalmazó mérés végrehajtása; ennek kiértékelése során az illesztési paraméterek inicializálása $\left(P_{1}\right.$, $P_{2}$ paraméterek, valamint a reciprok korrelációs idő).

- Minden második kép elkészítése egy kijelölt expozíciós idővel, melynek értéke a mintától függ. A korrelációs idő meghatározása függvényillesztéssel a kép alapján számított lokális kontraszt és az ismert $P_{1}$ és $P_{2}$ illesztési paraméterek segítségével.

- A fennmaradó képek a többi expozíciós idővel készültek, és segítségükkel a $P_{1}$ és $P_{2}$ paramétereket folyamatosan lehetett frissíteni.

A mérés a gyakorlatban a következőképpen történt. Kezdetben a rendszer minden expozíciós idő segítségével (1, 2, 5, 10, 20, 50, 100 ms) 5 képet készített az előzetes kalibráció elvégzéséhez, majd pl. 5 ms-os kijelölt expozíciós idő esetén ...-5-0-5-1 $5-2-5-10-5-20-5-50-100-\ldots$ ms ciklusokban rögzítette a képeket, ahol $0 \mathrm{~ms}$ a megvilágítás nélküli háttér képet jelöli.

Korábbi tapasztalataim alapján a kontrasztértékeket elronthatja a külső fényforrásokból érkező fény. A torzulás kiküszöbölésének érdekében egy, a kereskedelmi forgalomban is elérhető eszközökben alkalmazott módszerhez hasonló eljárást vezettem be. A háttérrel történő korrekcióhoz minden expozíciós idő sorozatban szükség volt egy „sötét” képre, amikor a lézerdióda ki volt kapcsolva (azaz amikor a lézerdióda meghajtóárama 40 mA-re lett állítva). Statisztikai megfontolásokból nem a „sötét” képkockát kell kivonni a „fényes” képekből (melyek során a lézerdióda megvilágítja a mintát), mivel ez a lokális szórás- és átlagértékek, illetve ezzel együtt a lokális kontrasztértékek torzulásához vezetne. Helyette inkább a „sötét” képek alapján számolt lokális variancia- (szórásnégyzet-) és átlagértékeket vontam ki a „fényes” képek alapján számított lokális variancia- és átlagértékekből. Így a lokális kontrasztértékek nem torzultak, viszont a háttérvilágítás által okozott torzulás szinte teljes mértékben sikerült kiküszöbölni: 


$$
K=\frac{\sqrt{\sigma^{2}-\sigma_{\text {sötét }}^{2}}}{\langle I\rangle-\langle I\rangle_{\text {sötét }}},
$$

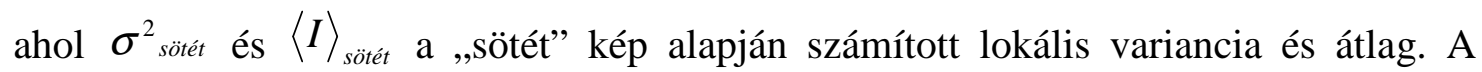
fentebb leírtaknak megfelelően a mérés során alkalmazott expozíciós idő sorozat, 5 ms-os kiválasztott expozíciós idővel a következőképpen képzelhető el: ... - 5-0 - 5-1 - 5-2 $-5-10-5-20-5-50-100-\ldots$ ms.

A mintavételezést végző program másodpercenként 5 kép rögzítését tette lehetővé. Ennek megfelelően a rendszer 400 ms-onként (minden második képkockát követően) tudott információt nyújtani a kijelölt területek vérellátását illetően.

Kíváncsi voltam arra, hogy a rendszer miként képes a környezet gyors és radikális változásait követni. Ennek tesztelésére a háttérvilágítást választottam, mivel ezt a tényezőt egy egyszerü lámpa segítségével gyakorlatilag egyetlen képkocka alatt is reprodukálhatóan, lépcsőszerűen lehet változtatni. A vizsgált minta egy $2 \mathrm{~V} / \mathrm{V} \%$ koncentrációjú, $650 \mathrm{~nm}$ átmérőjü latex mikrogömbökből álló szuszpenzióval töltött küvetta volt. Első lépésként elsötétítettem a laboratóriumot, hogy a lehető legkevesebb környezeti fény legyen jelen, majd körülbelül 20 másodperc elteltével felkapcsoltam a lámpát. A lámpát olyan távolságban helyeztem el, hogy a belőle származó fény kamera által látott intenzitása összemérhető legyen a szórási interferencia mintázat maximumaival. Az eredményt a 41. ábra mutatja be. A szuszpenzió esetén a mérésekhez kiválasztott expozíciós idő hossza $2 \mathrm{~ms}$ volt. A 41. ábra adatsorát tekintve a jel/zaj viszony lényegesen jobb annál, mint ami a „2. Elméleti összefoglalő” fejezetben szerepel ( $S N R \leq 4$ ). Ez annak köszönhető, hogy az ábrán szereplő kontrasztértékek egy nagyobb területhez tartozó lokális kontrasztértékek (laterális) átlagai. Biológiai minták (pl. agyfelszín) esetén egyszerre csupán piciny területek állnak megfigyelés alatt (pl. 30. ábra), így a kontrasztértékek komoly zajjal terheltek. 


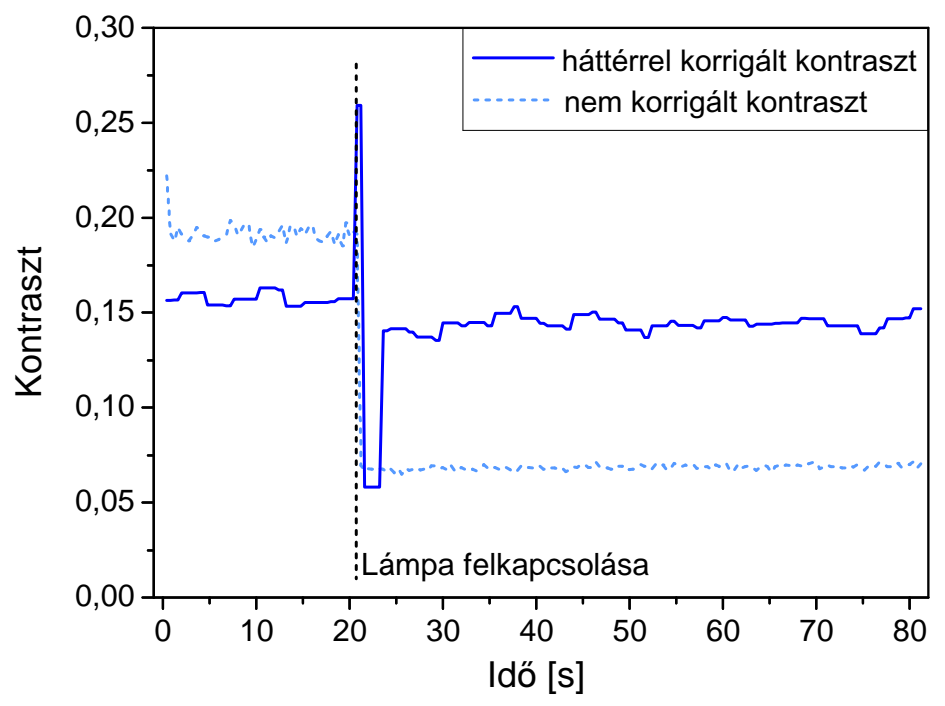

41. ábra. A kontrasztértékek alakulása a háttérrel való korrekció alkalmazása esetén (folytonos vonal) illetve a nélkül (szaggatott vonal), miközben 20 másodpercnél jelentősen megnő a környezeti fény mennyisége.

A reciprok korrelációs idő a kontrasztértékeknél lényegesen nagyobb arányú zajjal terhelt. Ennek magyarázata abban keresendő, hogy a $P_{1}$ és $P_{2}$ paraméterek értékének meghatározása több, hozzávetőleg azonos arányú, független zajjal terhelt kontrasztérték alapján, függvényillesztéssel történik, és a hibaterjedés miatt a két paramétert terhelő zaj aránya a kontrasztértékekéhez képest jelentősen megnő. A jel/zaj viszony további romlását eredményezi az is, hogy a reciprok korrelációs idő meghatározása a korábban meghatározott $P_{1}$ és $P_{2}$ paraméterek, valamint a legfrissebb kép alapján számított (szintén független zajjal terhelt) kontrasztérték segítségével történik. Ez szükségessé tette az időbeli átlagolás bevezetését. Futóátlag megvalósítása több expozíciós idő alkalmazása (és folyamatos váltogatása) esetén nehézkes lett volna, mivel minden expozíciós időhöz definiálni kellett volna egy-egy változtatható méretű puffert, ami LabVIEW környezetben a jelentősen megnövelte volna forráskód, a számítási idő és a felhasznált memória mennyiségét. Így az annál jóval egyszerűbben implementálható csökkenő átlag mellett döntöttem (ami a nemzetközi szakirodalomban decaying average néven található meg). Bár maguk a lokális kontrasztértékek is átlagolhatóak lettek volna, statisztikai megfontolásokból inkább a lokális variancia- és átlagértékek időbeli átlagolása mellett döntöttem, majd ezek alapján határoztam meg az átlagos lokális kontrasztértékeket. A módszert a következő összefüggés szemlélteti: 


$$
K^{2}{ }_{a v g}=\frac{(1-m) \cdot \sigma_{r e ́ g i}^{2}+m \cdot \sigma^{2}{ }^{2}{ }_{i j}}{\left[(1-m) \cdot\langle I\rangle_{r e ́ g i}+m \cdot\langle I\rangle_{i j}\right]^{2}},
$$

ahol $m$ az átlagolás súlya. A régi index a korábbi értékek átlagát, az új index pedig a legutoljára elkészült kép alapján számított értéket jelzi. Hasonló átlagolást vezettem be az SCPU értékek esetén is:

$$
S C P U_{a v g}=(1-n) \cdot S C P U_{r e ́ g i}+n \cdot S C P U_{u j j}
$$

ahol $n$ az átlagolás súlya. A régi és az új index szerepe itt is hasonló. A két független súly ( $m$ és $n$ ) bevezetésére azért volt szükség, mert a kontrasztértékek és az illesztés eredményeinek eltérő átlagolása sok esetben megfelelőbb eredményt adhat. Úgy találtam, hogy a rendszer reakcióidejét és a jel/zaj viszonyt figyelembe véve a legjobb kompromisszumot az $m=0,7$ és $n=0,35$ kombináció adta. A mérés során, közel valós időbeli felbontással meghatározott SCPU értékeket a 42. ábra mutatja. Jól látható, hogy bár a lámpa felkapcsolása jelentősen megzavarta a rendszert, a háttérrel való korrekció segítségével hamarosan ismét az eredeti értékeket mutatta.

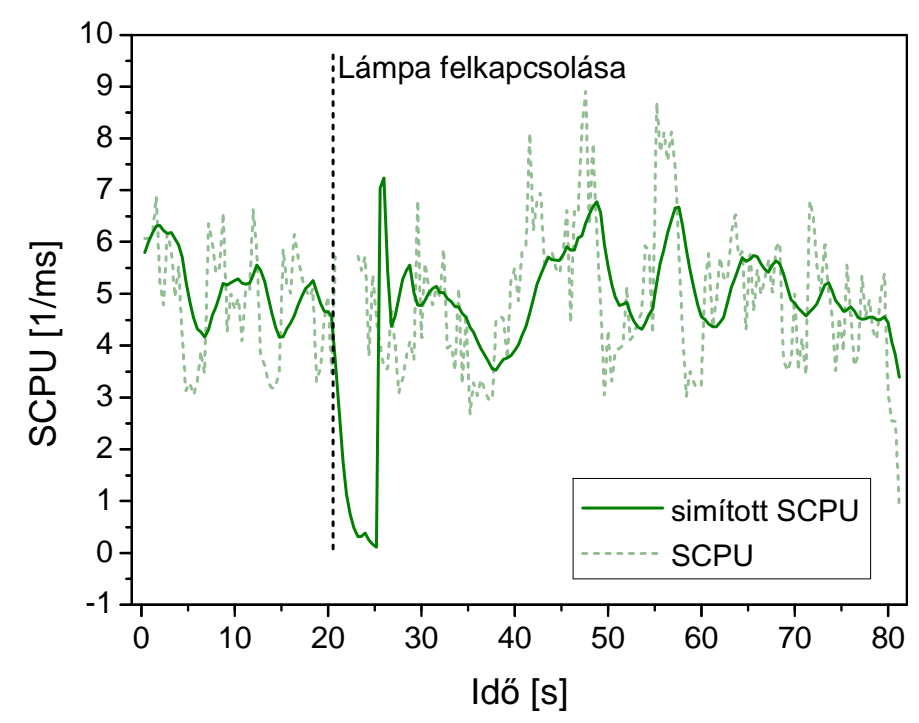

42. ábra. A rendszer által mért reciprok korrelációs idő latex mikrogömb szuszpenzió esetén, miközben jelentösen megnö a környezeti fény mennyisége. 
Az ábrán megmutatkozik a csökkenő átlag alkalmazásának előnye és hátránya: segítségével az SCPU értékeket terhelő nagyarányú zaj $(S N R<2)$ okozta fluktuációk elsimíthatóak ( $S N R \approx 3$ ), azonban ezzel együtt csökken a rendszer reakcióképessége: 2,5 másodperc (20-22,5 az ábrán) helyett hozzávetőleg 5 másodperc (20-25 az ábrán) szükséges a teljes alkalmazkodáshoz.

\subsection{Mérések áramló szuszpenzión}

Az áramló szuszpenzión végrehajtott mérések hasonlóan zajlottak le, mint folytonos megvilágítás esetén. Az eredményeket a 43.ábra mutatja be [60].

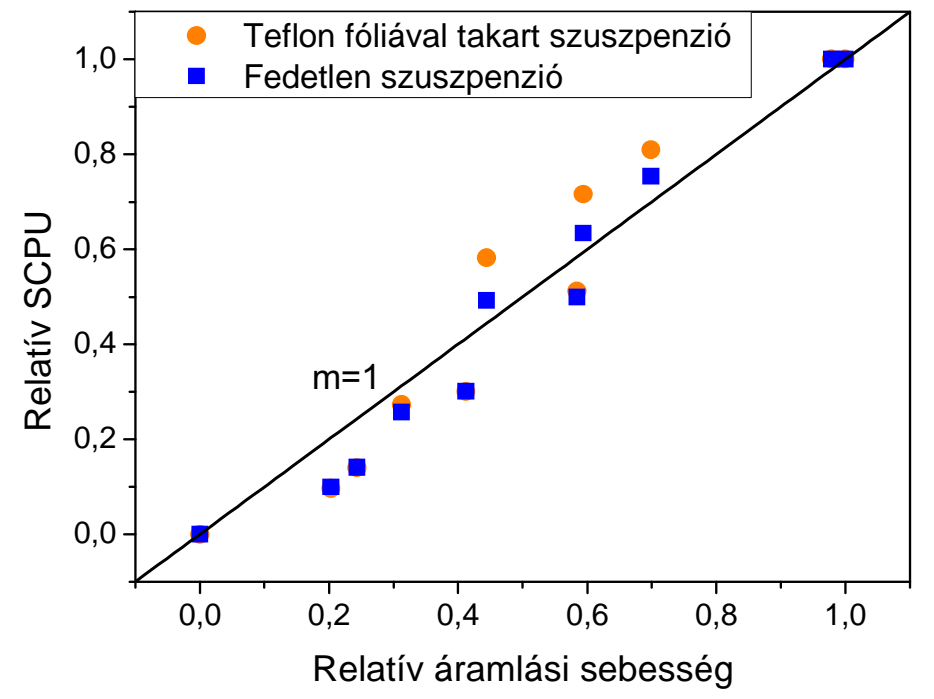

43. ábra. Fedetlen és 50 um vastag Teflon fóliával takart szuszpenzión mért relatív reciprok korrelációs idők. Segítségként az ábrán szerepel az $m=1$ meredekségü egyenes is.

A módszer sajátossága, hogy megfigyeléseim alapján a folytonos megvilágítás esetéhez képest már alacsonyabb sebességnél is telítődést mutat, mint folytonos megvilágítás esetén. Ennek magyarázata lehet az, hogy a felvillanások közötti „,ötét” szakaszok miatt az egyes felvillanások során keletkező, közel statikus interferenciaképek egymáshoz képest részben dekorreláltak. Az áramlási sebesség növekedésével ez a dekorreláció is növekedik, és ezt a rendszer csak addig képes követni, amíg az egyes felvillanások során keletkező interferenciaképek teljesen dekorreláltá nem válnak a 10 ms-nál rövidebb expozíciós idők 
esetén is: ekkor már csak nagy bizonytalansággal lehet görbét illeszteni a kontrasztértékekre, és így az áramlási sebesség megállapítása nem lehetséges.

Ideális esetben nagyszámú, igen rövid impulzus alkalmazására lenne szükség. Sajnos a rendelkezésre álló eszközök és alkatrészek (a véges hosszú fel- és lefutási idők miatt) csak erősen korlátozott számú felvillanást tesznek lehetővé. Mivel célom egy, a bőrszövet vérellátásának vizsgálatára alkalmas orvosi eszköz alapjainak lefektetése volt, így a nagyobb sebességek mérhetőségével szemben a rendszer hosszú ideig tartó stabil müködését és az elérhető legnagyobb fényerőt helyeztem az előtérbe.

\subsection{Bőrszövet vérellátásának vizsgálata}

A kapcsolóüzemủ megvilágítást alkalmazó kísérletekhez használt elrendezés vázlata a 44. ábrán látható. A folytonos megvilágítást alkalmazó módszertől való legfőbb eltérés a neutrális szürő hiánya és a kapcsolóüzemü vezérlés. További különbség, hogy nagyobb látószögű objektívet alkalmaztam, mint a korábbi mérések során, így lehetőség nyílt egyszerre nagyobb terület (körülbelül $20 \mathrm{~cm}^{2}$ ) megfigyelésére.

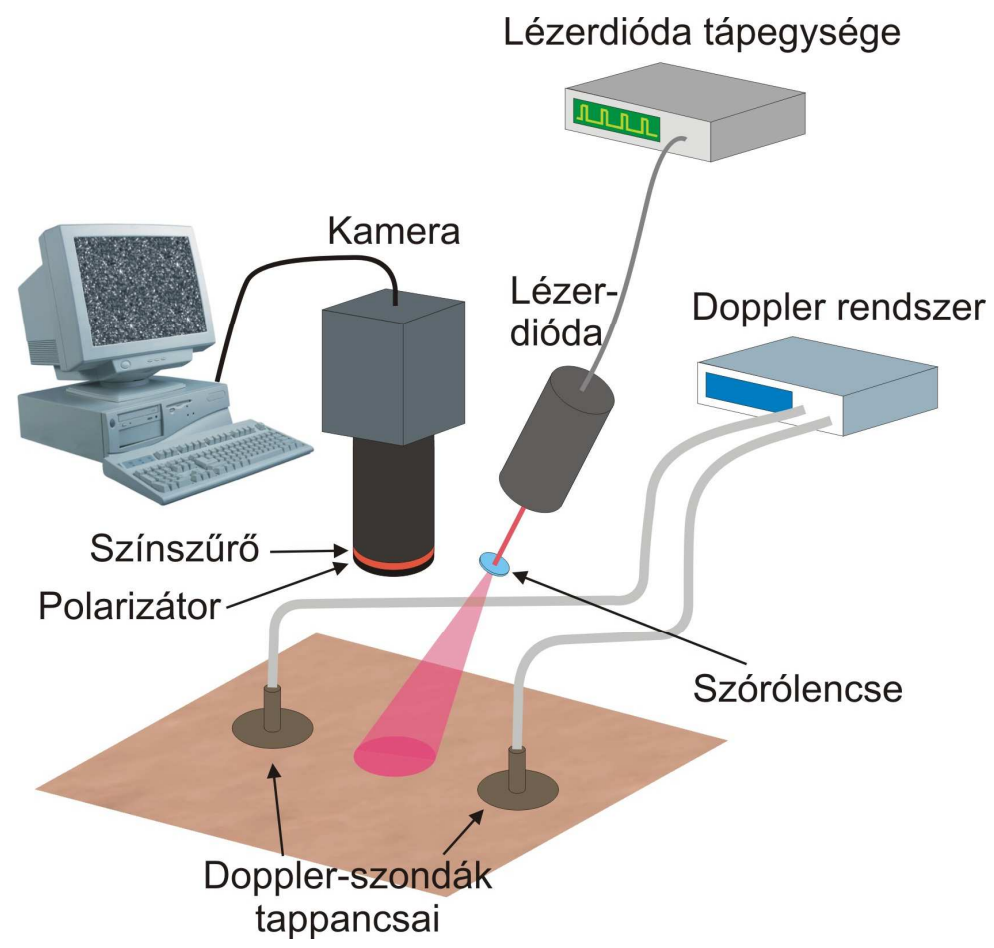

44. ábra. A kapcsolóüzemü megvilágítást alkalmazó mérések során használt elrendezés. 
A mérési protokoll a „7. Bőrszövet vérellátásának vizsgálata” c. fejezetben leírtakhoz hasonló volt. Azonban, mivel a mérörendszer minden második felvételt követően képes volt információt adni az áramlás tulajdonságairól, és a szövet tulajdonságainak megfelelően folyamatosan, automatikusan kalibrálta magát, lehetőség nyílt az állandósult állapotok közti átmenetek eredményeinek összehasonlítására is. Így az egyes vizsgálatok esetében nem 3 különálló mérésröl, hanem egyetlen, de három szakaszból álló mérésről beszélhetünk. Egy vérnyomásmérő mandzsettáját elöre felhúztam az alany felkarjára. Ekkor nem pumpáltam bele levegőt, csupán azért volt szükség erre, hogy ne kelljen megszakítani a mérést. Nyugalmi állapotban kezdtem meg a mérést, majd a mandzsettában a szisztolésnél 30-35 Hgmm-rel magasabb nyomást létrehozva jelentősen lelassítottam a véráramlást az alkarban (okklúzió). Miután a Doppler és a speckle rendszer által mutatott áramlási sebesség állandósult, megszüntettem az elszorítást (reperfúzió). Mivel bőrszövet esetén a $K(T)$ görbe inflexiós pontja 5 és 20 ms között található, így a mérések során kiválasztott expozíciós idő hossza 10 ms volt.

A kapcsolóüzemü vezérlés és a mintavételezés által biztosított közel valós idejü monitorozás egyik óriási előnye abban mutatkozott meg, hogy az elszorítást követően elegendő volt körülbelül fél percet várni, majd megszüntethettem a szorítást. Így a korábbi, hozzávetőleg másfél perc helyett jóval rövidebb ideig volt elszorítva a jelentkezők karja, ami nagymértékben javította a komfortérzetüket. A módszer másik előnyét a kiértékelés során tapasztalhattam meg: az általam fejlesztett alkalmazás automatikusan elvégezte azt, így az Origin szoftverre csupán az eredmények ábrázolásához volt szükség. Ez jelentősen meggyorsította a folyamatot, és a korábbi 1-1,5 óra helyett csupán 20 percbe telt egy méréssorozat teljes kiértékelése és ábrázolása.

Mivel a bőr valós időben történő megfigyelése esetén a $P_{1}$ és $P_{2}$ paraméterek is jelentős zajjal terheltek, így ezekre is alkalmazni kellett a (77) formulában látott futóátlagot:

$$
\begin{gathered}
P_{1, a v g}=(1-n) \cdot P_{1, \text { régi }}+n \cdot P_{1, u j j}, \\
P_{2, a v g}=(1-n) \cdot P_{2, r e ́ g i}+n \cdot P_{2, u j j} .
\end{gathered}
$$

Az eredmények kiértékelése során mérlegelnem kellett a futóátlag súlyozását: túl magas súly nem csökkentette volna kellő mértékben a véletlenszerü fluktuációkat, míg túl alacsony súly jelentősen rontotta volna a rendszer reakcióképességét. Végül a kontrasztértékek esetén a 0,7, míg a sebességek és az illesztési paraméterek esetében a 0,35 
értéket választottam, mivel számos beállítás közül ez bizonyult a legjobb kompromisszumnak.

Nyolc jelentkezőn összesen 16 mérést végeztem. A „7. Börszövet vérellátásának vizsgálata" c. fejezetben leírtakhoz hasonlóan itt is azok a mérések lettek kizárva, amelyek során egymásak ellentmondó változásokat mutatott a speckle és a Doppler rendszer. A 45. ábra egy reprezentatív mérés eredményét mutatja.

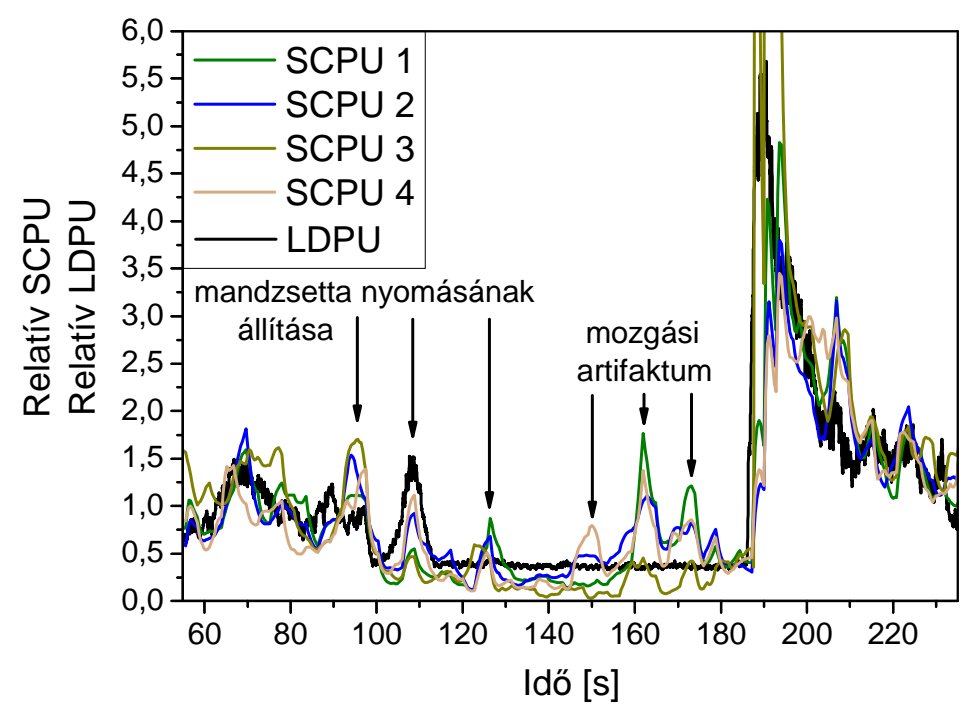

45. ábra. A speckle és a Doppler rendszer által mutatott eredmények egy reprezentatív mérés során. A speckle rendszert jelentösen megzavarhatja a vizsgált szövet elmozdulása, mivel mozgási artifaktumok keletkezhetnek. Mivel a Doppler-szondák rögzítve voltak a börfelszínhez, így azok nem érzékelték az elmozdulást. Figyelemre méltó, hogy ugyanakkor mindkét mérörendszer eredményeiben megjelent a mandzsetta nyomásának változtatása, és a mozgási artifaktumoktól eltekintvejól egyeznek az eredmények. A speckle rendszer 4 kijelölt területet vizsgált egyszerre.

Kiválóan látszik, hogy az általam fejlesztett rendszer reakcióideje megfelelőnek bizonyult a bőr perfúziójában bekövetkező relatív gyors változások követésére is, annak ellenére, hogy Doppler rendszer mintavételi frekvenciája körülbelül 25-ször nagyobb $(64 \mathrm{~Hz})$ az előbbiénél $(2,5 \mathrm{~Hz})$. Mivel a két eszköz eltérő mennyiségeket ad eredményül, így relatív értékeket ábrázoltam. Az általam fejlesztett kiértékelő program egyszerre 4 kijelölt területen tudta figyelni a szövet vérellátását, így az ábrákon is négy terület eredményei láthatóak. A területek nagysága hozzávetőleg 50×50 pixel ${ }^{2}$ a kontraszttérképeken (ami a 
bőrfelszínen nagyjából 2-4 $\mathrm{cm}^{2}$ ), és az egyes területeken számított lokális kontrasztértékek átlagait használtam a mérésekhez. Az ábrán az is látható, hogy - mint minden nagyobb terület monitorozására alkalmas áramlásmérő rendszert - az általam épített rendszert jelentősen megzavarhatja a minta elmozdulása. Bár Mahé és munkatársai bemutattak egy módszert az elmozdulás kompenzálására [61], ennek implementálása az általam épített, több expozíciós időt alkalmazó rendszer esetén a kutatók által leírtnál lényegesen bonyolultabb lett volna, és a disszertáció megírásáig nem történt meg.

A 46. ábra foglalja össze a mérések eredményeit. Minden mérés során olyan időintervallumok átlagos SCPU értékeit ábrázoltam, mely intervallumokon a jel nem volt mozgási artifaktumoktól terhelt. A folytonos megvilágításnál végrehajtott mérésekhez hasonlóan itt is 1-nek vettem az alapállapotban mért perfúziós értékeket mindkét rendszer esetén, majd az ehhez képesti relatív változásokat ábrázoltam az okklúzió és a reperfúzió során. Az egyenest úgy illesztettem, hogy átmenjen az $(1,1)$ ponton, így az egyenes meredeksége a két rendszer által mutatott változások arányát jellemzi.

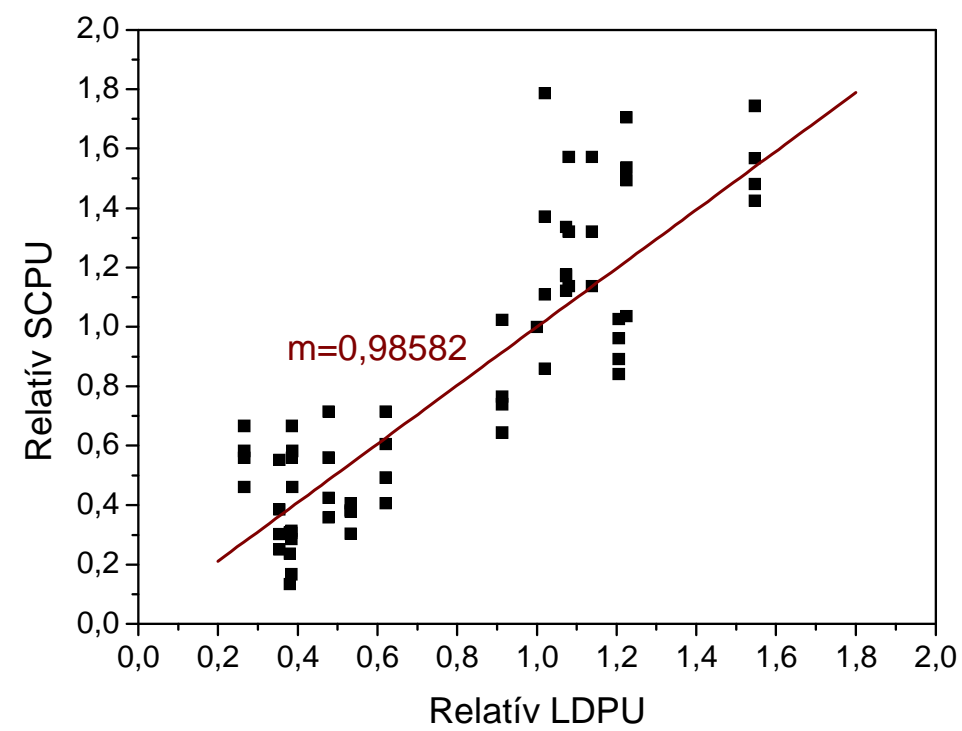

46. ábra. A kapcsoloüzemü megvilágítást alkalmazó, közel valós idejü módszerrel meghatározott relatív SCPU értékek a Doppler-rendszer által mutatott relatív LDPU értékek függvényében. Az alapállapotban meghatározott értékeket 1-nek vettem, majd mindkét rendszer esetén az ehhez képesti változásokat ábrázoltam.

Szembetűnő, hogy a két rendszer által mutatott eredmények átlagosan igen jó összhangban vannak, az általuk mutatott relatív változások nagyságának átlaga 98\%-os egyezést utat, 
ami messze meghaladja a korábban elért pontosságot. Ez az eredmény azért is kiemelkedő, mert legjobb ismereteim alapján a szakirodalomban közzétett börfelszíni mérések eredményei jelentős additív taggal terheltek a speckle és a Doppler rendszerek linearitásának tekintetében [62], [63].

Bár a fent leírt mérési és kiértékelési eljárás közel valós idejű eredményeket tud szolgáltatni a kezelő által kijelölt területek vérellátottságával kapcsolatban, a valós mérések során elengedhetetlenül fontos, hogy a vizsgálatot végző személy a teljes vizsgált terület közel valós idejü perfúzió térképét is láthassa. Sajnos egy hozzávetőleg 300×200 pixel felbontású (ami a kontraszttérképek felbontása) $1 / \tau$ térkép meghatározása pixelről pixelre a fent leírt, függvényillesztésen alapuló módszer segítségével több órát venne igénybe. Ezért kidolgoztam egy előre definiált értékeket tartalmazó táblázatokon alapuló közelítő módszert, ami lehetővé tette azt, hogy egy $1 / \tau$ térkép meghatározása csupán kevesebb, mint 0,2 másodperc alatt megtörténhessen. Ennek részletes leírását a „9. A mérésekhez és az eredmények kiértékeléséhez használt szoftver kifejlesztése” c. fejezetben találja az Olvasó.

A nagy sebességü, sebességtérképek megjelenítését is lehetővé tevő módszerrel megvizsgáltam, hogy egy ujj elszorítását miként képes követni az általam fejlesztett rendszer. A mérések során egy eredetileg újszülöttek vizsgálatára készült karmandzsettát alkalmaztam, amit felhúztam a vizsgált alany ujjára. Ezt követően a mérés menete megegyezett a korábbiakkal, az eredményeit a 47. ábra demonstrálja. A disszertáció digitális mellékeltében megtalálható a mérés során készült videó is. Kíváncsi voltam, hogy egy hideg tárgy érintése esetén hogyan változik a bőrszövet vérellátása. A mérés során egy hideg fémtárgyat helyeztem egy önként jelentkező alkarjához, majd körülbelül fél perc elteltével elvettem onnan. A bőr reakcióját a 48. ábra mutatja be. Jól látszik a képsorozaton, hogy csak azok a területek reagáltak a hidegre, amelyek ténylegesen érintkeztek a tárggyal. A tárgy anyagába fúrt lyukak helyén a perfúzió nem változott számottevően. A disszertáció digitális mellékletében megtalálható az ezen és egy további mérés során készült filmfelvétel. A filmfelvétel elkészítésével kapcsolatos további információkat a „9. A mérésekhez és az eredmények kiértékeléséhez használt szoftver kifejlesztése” c. fejezetben találhat az Olvasó. A tárgyról készült fénykép a 49. ábrán látható. 

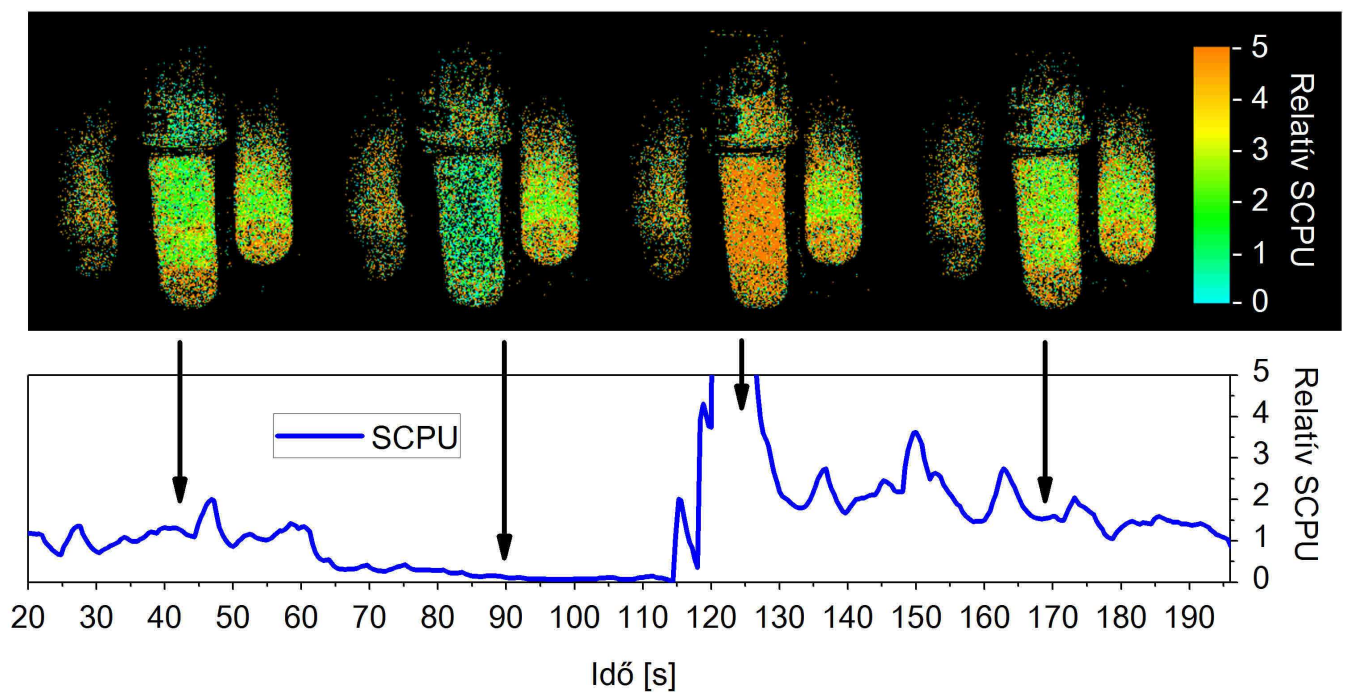

47. ábra. Az ujj vérellátásának változása a vérnyomásmérö mandzsettájának felfújása és leengedése hatására. Az ábra felsö részén sebességtérképek láthatóak, míg alsó részén sebességgrafikon mutatja a stimulált szövetben lévő perfúzió intenzitását. A nyilak a képek elkészültének időpontjait, illetve a görbe vonatkozó részeit mutatják.

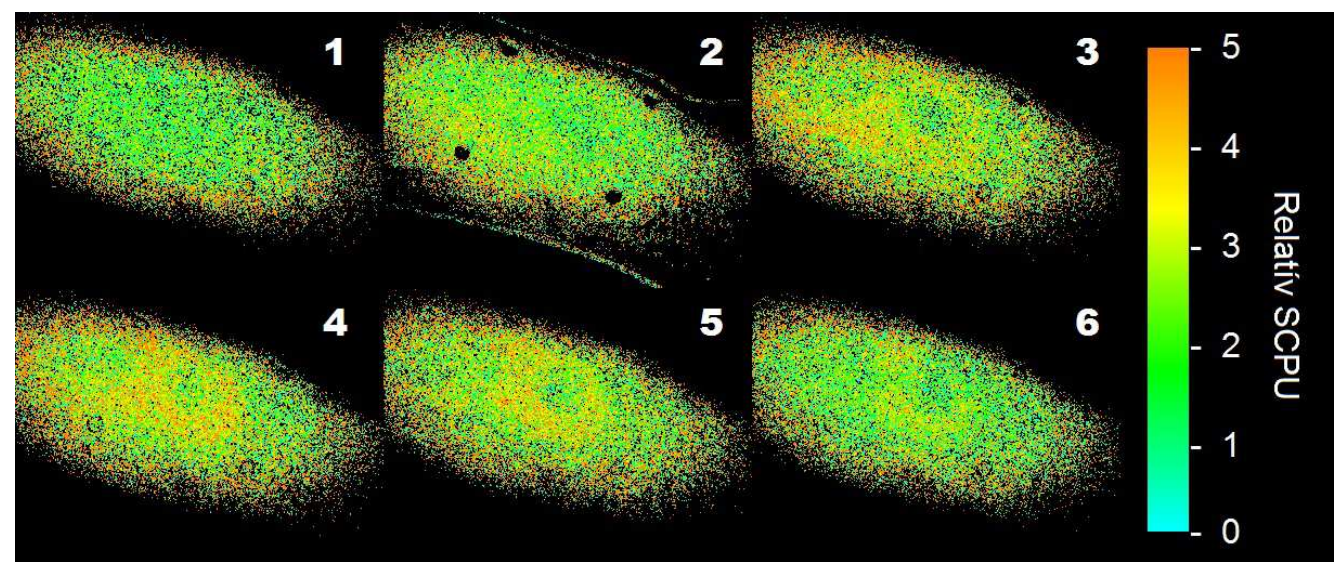

48. ábra. A bör reakciója egy hideg tárgy érintésére. Jól látszik, hogy csak azon területek reagáltak a hidegre, amelyek ténylegesen érintkeztek a tárggyal. A négy sötét pötty a bőrfelszín esetleges elmozdulásának jelzésére szolgál. 


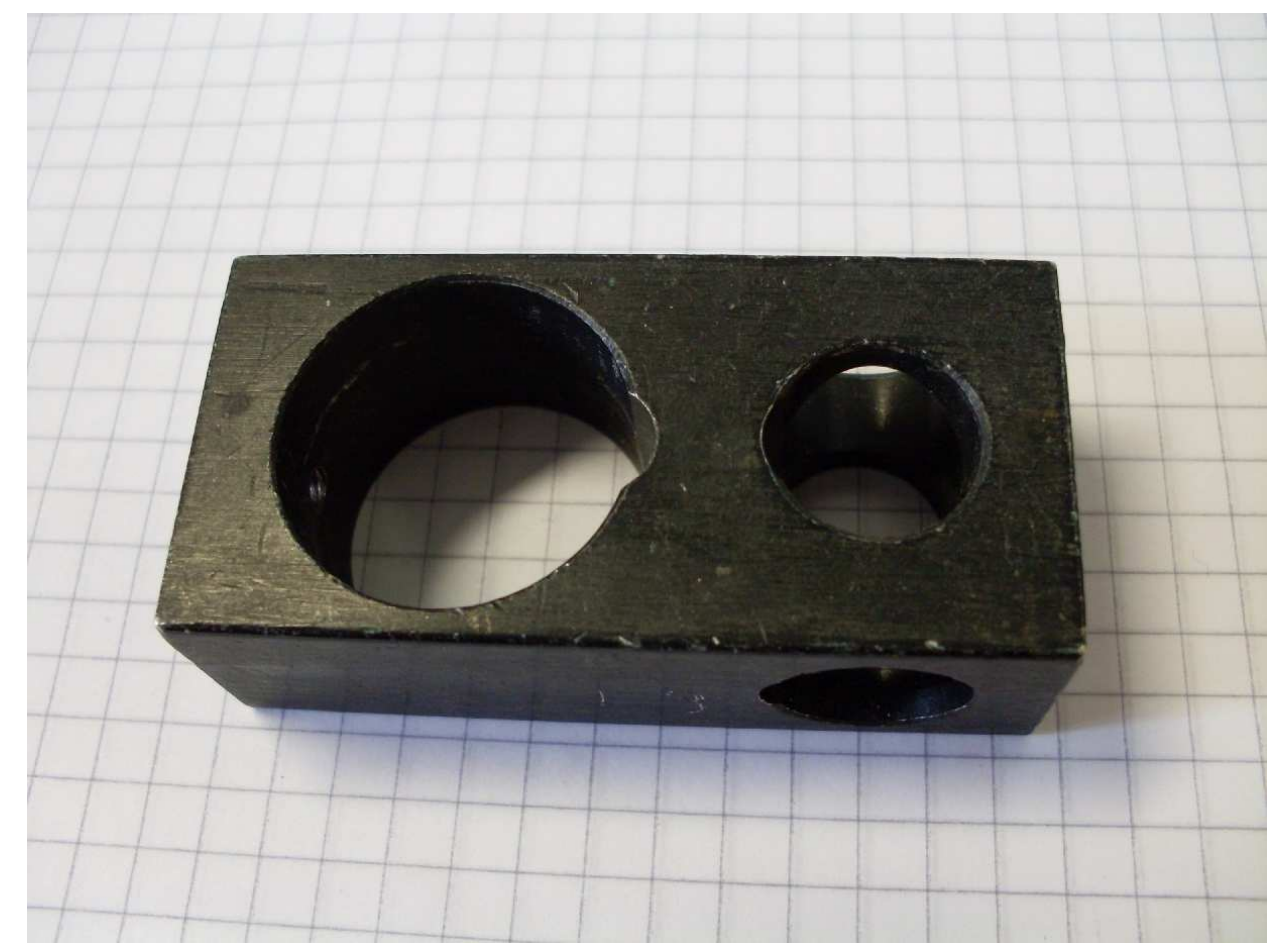

49. ábra. A lehütött tárgyról készüll fénykép.

Bár a rendszer a dolgozat elkészültékor 5 képkockát volt képes rögzíteni másodpercenként, a mintavételező algoritmus továbbfejlesztésével, valamint az 1, 3, 9, 27, 81 ms-os (valamint a lézerdióda kikapcsolt állapota) expozíciós idő készlet segítségével elérhetővé válna a másodpercenkénti 10 képkocka felvétele, így a perfúziós értékek kétszer akkora rátával lennének megjeleníthetők. Mivel 2-vel kevesebb expozíciós idő lenne alkalmazva, így az illesztési paraméterek is csaknem háromszor olyan gyorsan frissülnének, mint a dolgozat megírásának idején. Mindez még tovább növelné a rendszer reakcióképességét. 


\section{A mérésekhez és az eredmények kiértékeléséhez használt szoftver kifejlesztése}

Bár dolgozatom célja egy orvosi célokra használható eszköz fejlesztése fizikai vonatkozásainak bemutatása, azonban fontosnak tartom megemlíteni, hogy a kutatásra fordított időm jelentős részét (több mint felét) a megfelelő informatikai háttér megalkotása és továbbfejlesztése töltötte ki. Ezért a szoftverek fejlesztésének menetét, illetve az alkalmazott algoritmusok alapjait ebben a különálló fejezetben szeretném bemutatni.

\subsection{Képrögzítés}

A több expozíciós időt alkalmazó szórási interferencia kontrasztelemzés (,,Multiexposure LASCA”) során az expozíciós időt széles tartományon változtatják, majd az egyes képek esetén megállapított lokális kontrasztértékek alapján megbecsülik a vér áramlási sebességét a szövetben. Sajnos a leképező optika (munkatávolság, apertúra) és a lézerdióda (meghajtó áramerősség, hőmérséklet) paramétereinek hangolása a kontrasztértékek torzulásához vezetett volna, így a megvilágítás intenzitását egy folytonosan változtatható erősségű neutrális szürővel kellett beállítani. A képrögzítő program elvárt funkciói a következők voltak:

- Adott számú kép időzített rögzítése egyetlen expozíciós idő alkalmazásával

- Képek időzített rögzítése egyetlen expozíciós idő alkalmazásával a felvétel leállításáig

- Adott számú kép rögzítése több expozíciós idő felhasználásával, a szűrő automatikus mozgatásával a fényerő helyes beállítása érdekében

A szoftver fejlesztését 2008 során témavezetőm kezdte LabVIEW 7.1 környezetben, majd ezt a feladatot fokozatosan átvettem tőle. Az első működő változat esetén a szürő mozgatása a léptetőmotor vezérlőjének hiányosságai miatt igen lassan történt, valamint a kamera meghajtójának hibái is sok kellemetlenséget okoztak. A kamera cseréje illetve a vezérlő firmware-jének frissítése nagymértékben megkönnyítette munkánkat a továbbiakban, rövid időn belül jelentősen csökkent a felvételek elkészítéséhez szükséges idő, valamint nőtt a program megbízhatósága is.

A program egyetlen cikluson belül végzett el minden feladatot: az expozíció vezérlését, a kép elmentését egy kiválasztott formátumban, a kontraszttérkép kiszámítását és 
megjelenítését, a kijelölt területeken számított átlagos kontrasztértékek ábrázolását és néhány egyéb statisztikai adat megjelenítését. Mivel a kontraszttérkép és az egyéb statisztikai adatok (fényesség- és kontrasztérték-hisztogramok) kiszámítása meglehetősen erőforrásigényes feladatok voltak, a program másodpercenként 3-4 kép felvételét tette lehetővé. A mintavételi sebesség javítására irányuló első, kisebb fejlesztés során opcionálisan kikapcsolhatóvá tettünk néhány funkciót, melynek nyomán a mintavételi sebesség elérhette akár a másodpercenkénti 7 képkockát is.

A szoftveren végrehajtott első komoly fejlesztést 2010-ben végeztem el. Ennek során három független szálra bontottam a végrehajtást. Az első az expozíció vezérlését és a képek elmentését végezte. A második a kontraszttérkép, a kijelölt területek átlagos kontrasztjai és a hisztogramok kiszámítását, valamint ezek megjelenítését végezte. A harmadik szál a léptetőmotor vezérlését látta el. Ez a struktúra lehetővé tette, hogy a mintavételezési sebesség bármely körülmények között elérhesse vagy akár meg is haladhassa a másodpercenkénti 8 képkockát. Mivel az erőforrásigényes feladatok (kontrasztértékek és -térképek, valamint hisztogramok számítása) egy, a többitől független ciklusban folytak, a két processzormagot tartalmazó számítógép esetén nem lassították a képek rögzítését. A léptetőmotor vezérléséhez azért volt szükség a harmadik ciklus bevezetésére, mert így nem kellett a feladattal járó bonyolult feltételrendszert a felvételt vezérlő vagy a számításokat végző cikluson belül kezelni. A fejlesztés során mélyebben elsajátítottam a LabVIEW programozási nyelv és környezet használatát, valamint jelentősen növeltem a forráskód átláthatóságát.

Az újabb funkciók bevezetése a forráskód folyamatos változtatását tette szükségessé, ami egyre rontotta annak áttekinthetőségét és kezelhetőségét. Végül a tömbök hatékonyabb kezelése és a fejlettebb megjelenítő eszközök végett szükségessé vált, hogy áttérjek a LabVIEW 11-es verziójára. Sajnos az áttérés nem volt zökkenőmentes: az egymástól független időzített ciklusok kezelése nem müködött megfelelően, és a program meglehetősen gyakran (óránként többször is) véletlenszerüen lefagyott. Mivel ez komoly gondot jelentett az Élettani Intézetben folytatott mérések során, így 2011-ben elkezdtem egy új felépítésủ program megtervezését és megírását. A program elvárt funkciói a következők voltak:

- Adott számú kép időzített rögzítése egyetlen expozíciós idő alkalmazásával

- Képek időzített rögzítése egyetlen expozíciós idő alkalmazásával a felvétel leállításáig 
- Adott számú kép rögzítése több expozíciós idő felhasználásával, a szürő automatikus mozgatásával a fényerő helyes beállítása érdekében

- Két kijelölt területen mért kontraszt- és sebességértékek (közel) valós időben történő kijelzése

- Több expozíciós időt felhasználó (közel) valós időben történő sebességmérés, reciprok korrelációs idő térkép megjelenítése, a kontraszt- és sebességértékek kijelzése két kijelölt terület esetén

További kívánalom volt, hogy az erőforrásigényes feladatok ne tarthassák fel a képek rögzítését és az expozíció vezérlését.

A program minden feladatkörhöz külön szálat alkalmazott, melyek prioritása az elvégzendő feladatok függvényében változott. A program gördülékeny müködése érdekében az expozíciót és a pufferműveleteket vezérlő két szál az 1. processzormagot vette igénybe. A 2. processzormagot vették igénybe a képek elmentését, a valós időben történő mérések elvégzését, a kontraszt- vagy sebességtérképet számító és megjelenítő, valamint a léptetőmotor vezérlését végző szálak, melyek prioritása a felsorolás sorrendjében csökkent. Ez a struktúra lehetővé tette, hogy ha befejeződött egy kép expozíciója, akkor a képadat zavartalanul eljuthatott azokhoz a szálakhoz, amelyek befejezték munkájukat az előző képpel kapcsolatban. Ha azonban egy feladat hosszúra nyúlt (például részletgazdag kontraszttérképek vagy sebességtérképek számítása és megjelenítése esetén), az nem tartotta fel a többi folyamatot, például a képek elmentését vagy a kijelölt területekre vonatkozó on-line eredménykijelzést.

Mivel korábban nem készítettem ilyen összetett, több szálon futó, párhuzamos végrehajtást megvalósító algoritmust, így komoly kihívást jelentett a feladat. Különösen nagy gondot fordítottam a szálak szinkronizálására (pl. a program indítása, leállítása során, valamint a mérés típusának - egyetlen expozíciós idő, több expozíciós idő szűrővel, kapcsolóüzemü fényerő-szabályozáson alapuló mérések - változtatása esetén) és a szálak közötti mester-szolga viszonyok kialakítására. Az Élettani Intézet munkatársai hasznos tanácsaikkal, változatos tesztkörülmények létrehozásával és részletes beszámolóikkal sok segítséget nyújtottak a felhasználói felület kialakításához és program rejtett hibáinak kijavításához.

Ahogy azt a „8. Az időbeli felbontás javitását megcélzó fejlesztések” c. fejezetben részleteztem, a közel valós időben történő több expozíciós időt alkalmazó mérés során egy új protokollt alkottam, ami magában egyesítette a több és az egyetlen expozíciós időt alkalmazó mérések előnyeit. A protokoll leírása a következő: 
- A mérés kezdetén egy hagyományos, több expozíciós időt alkalmazó mérés végrehajtása; ennek kiértékelése során az illesztési paraméterek inicializálása.

- Minden második kép elkészítése egy kijelölt expozíciós idővel, melynek értéke a mintától függ. A korrelációs idő meghatározása függvényillesztéssel a kép alapján számított lokális kontraszt és az illesztési paraméterek segítségével.

- A fennmaradó képek a többi expozíciós idővel készültek, és segítségükkel az illesztési paramétereket folyamatosan lehetett frissíteni.

\subsection{Kapcsolóüzemü fényerö- és expozíciósidő-szabályozás}

A megvalósítás első lépéseként a Müszaki és Anyagtudományi Intézet munkatársai készítettek egy Atmel ATMega16 mikrovezérlő köré épülő vezérlőpanelt. A mikrovezérlő egy UART-USB átalakítón keresztül tudott kommunikálni a számítógéppel. Képes volt triggerjelet adni a kamerának az expozíció megkezdéséhez, valamint egy LTC1451 típusú D/A konverter segítségével tetszőleges feszültséget tudott előállítani egy arra kialakított kimeneten.

Első feladatom a vezérlőpanel firmware-jének megalkotása volt AVRStudio 4 környezetben. Az első, korlátozott eszközkészlettel rendelkező változat megírása után bebizonyosodott, hogy a funkcionalitás későbbi bővíthetősége érdekében (pl. két lézerdióda vezérlése, elektrooptikai vagy akusztooptikai modulátor vezérlése, az időzítés hangolása, stb.) egy gondosan megtervezett kommunikációs protokoll kidolgozása szükséges. Ennek köszönhetően egyetlen panel segítségével számos lehetséges alkalmazás igényei kielégíthetőek lettek. A kommunikációs protokoll folyamatábráját a 50. ábra mutatja. A kommunikációt mindig a számítógép kezdte azzal, hogy elküldte a végrehajtandó parancs karakterét (hexadecimális sorszámát). Minden kiadott parancs után a mikrovezérlőnek válaszolnia kellett (acknowledgement, ACK): vissza kellett küldenie a parancsot. Ezután, ha a parancshoz tartozott (1 vagy 2 bájtos) paraméter, akkor minden bájt után egy definiált ACK jelet kellett adnia a mikrovezérlőnek. 


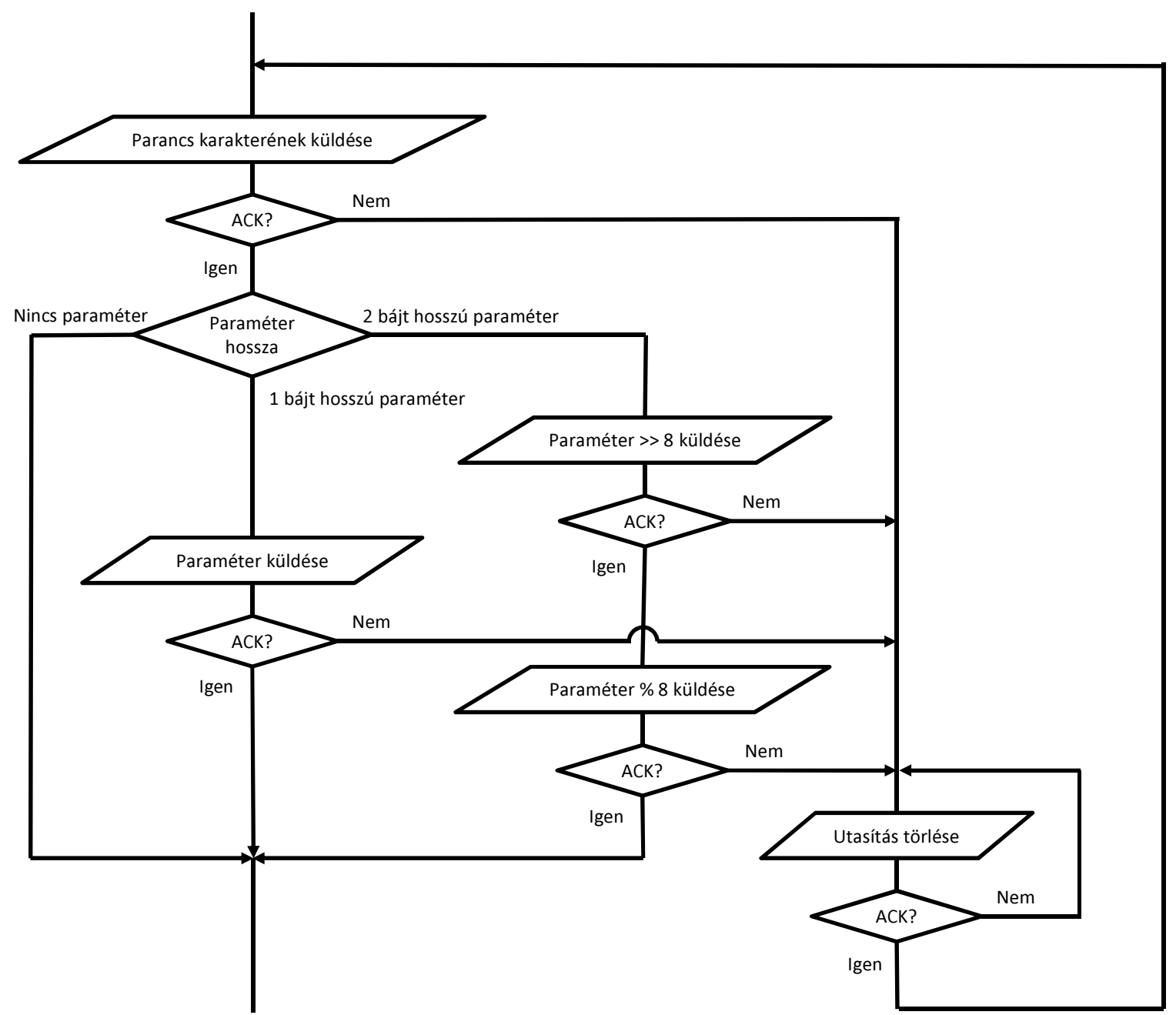

50. ábra. A számitógép és a mikrovezérlő közötti kommunikáció protokolljának folyamatábrája.

A firmware dolgozat megírásakor müködő változata lehetővé tette az expozíció hosszának, az expozíciók között alkalmazandó várakozások hosszának, az impulzusok tulajdonságainak (szám, offset, üresjárat, csúcs, kitöltöttség, stb.) akár mérés közben történő beállítását, valamint a megfelelő működéshez szükséges, számos további paraméter hangolását. A program kialakítása révén az új funkciók (pl. a kimeneti jel eltolódásának érzékelése és beállítása) bevezetése gyorsan és egyszerüen megvalósítható.

A firmware fejlesztésével párhuzamosan egy olyan VI-t (Virtual Instrument, a LabVIEW környezetben fejlesztett program) is írtam, amely lehetővé tette a kommunikációt a vezérlőpanellel. Ez a VI adta a mérést végző program kommunikációt ellátó részeinek alapját is.

Következő feladatom az lett, hogy a módszert integráljam a mérőprogramba. Ennek során módosítani kellett annak szerkezetét, mivel a megvilágítás kapcsolóüzemü vezérlése 
a többi módszertől eltérő mester-szolga viszonyokat igényelt. A 51. ábra a mester-szolga viszonyokat mutatja folytonos megvilágítást, kapcsolóüzemü megvilágítást és egy expozíciós időt, valamint kapcsolóüzemü megvilágítást és több expozíciós időt felhasználó mérések során. A második és harmadik esetben praktikus volt szétválasztani a pufferműveleteket (a nyers képadat eljuttatását a feldolgozó szálakhoz) a képek fogadásától, mivel mindkét feladat időigényes, és egyetlen szálon belül feltartották volna egymást. Gyakorlatilag egy csővezetéket alakítottam ki a programon belül, így minden szálnak elegendő ideje van elvégezni a feladatát.
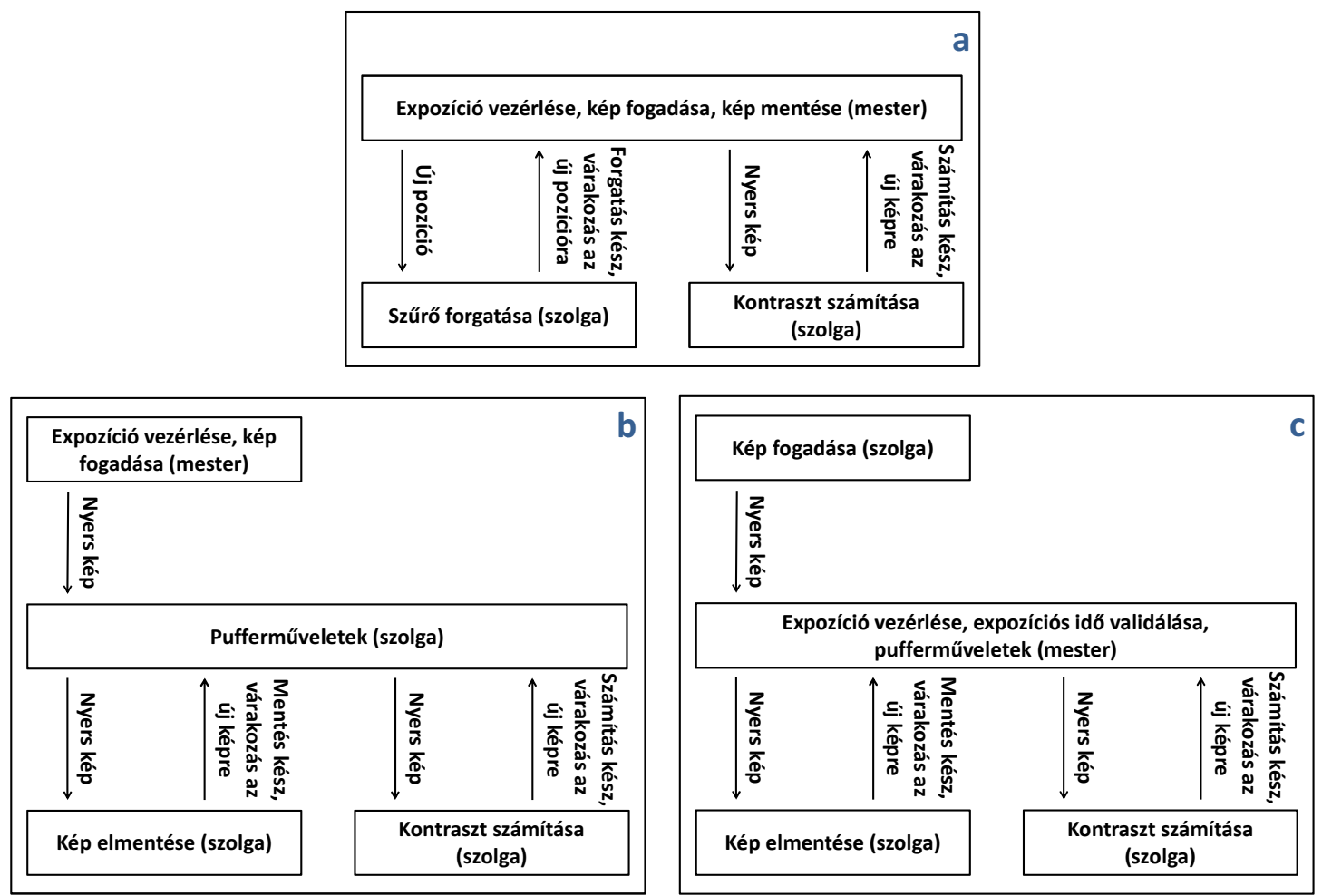

51. ábra. A szálak közötti mester-szolga viszonyok folytonos megvilágítás (a), kapcsolóïzemü megvilágítás és egy expozíciós idő(b), valamint kapcsolóüzemü megvilágítás és több expozíciós idő (c) esetén.

Bár a vezérlőpanel segítségével a folytonos megvilágítás is vezérelhető lett volna, azonban az Élettani Intézetben felállított eszköz a dolgozat megírásának idején nem rendelkezett ezzel a bővítménnyel. Ennek megfelelően különös gondot kellett fordítanom arra, hogy egyazon program alkalmazható legyen mindkét eszköz esetén.

\subsection{Közel valós idejű sebességtérkép kiszámítása és megjelenítése}


Elméletileg több expozíciós idő mellett rögzített képek esetén a belőlük számított kontraszttérképek azonos koordinátájú pixelei alapján is ki lehet számítani a korrelációs időt vagy annak reciprokját. Ha ezt minden pixelre elvégezzük, egy korrelációs idő térképet vagy sebességtérképet kapunk. Valójában a müvelet elvégzése több órát is igénybe vehet, és sok erőforrást igényel (három ilyen térkép kiszámítása 8 órán át tartott és két processzormag közül az egyiket teljesen, a másikat részben lefoglalta). A mérések, de még a részletes kiértékelések során sincs erre idő, viszont, mivel egy diagnosztikai eszközt kívántam építeni, így erről a funkcióról semmiképp sem szerettem volna lemondani.

A müvelet felgyorsításához arra volt szükség, hogy a mérőprogramnak ne kelljen a térképre vonatkozó számításokat elvégeznie. A probléma megoldásaként egy táblázatot készítettem, melyben elöre definiáltam az összes lehetséges kontrasztértékkombinációkhoz tartozó $1 / \tau$ értékeket.

Mivel 7 expozíciós időt alkalmaztam a mérések során, így a táblázat is hétdimenziós, és a vele járó intenzív memóriahasználat csökkentése érdekében minden dimenziója a [0..10] tartományon indexelhető, azaz összesen körülbelül 80 MB-nyi memóriát igényel. A hétféle expozíciós idővel készült képek alapján számolt kontrasztnégyzettérképek adott pixeleinek értékeit a program átskálázta és egészre kerekítette a [0..10] tartományon, majd az 1́gy nyert 7 egész számot a hétdimenziós tömb indexelésére használta. A táblázatban a 7 indexnek megfelelő helyen a normált és kerekített kontrasztértékekhez tartozó $P_{1}{ }^{2 *}, P_{2}{ }^{2 *}$ és $\tau$ szerepel. Ezt követően a program az átskálázás paramétereinek segítségével kiszámította az eredeti $K^{2}$ értékeknek megfelelő $P_{1}^{2}$ és $P_{2}^{2}$ értékeket, majd megvizsgálta, hogy ezek megfelelnek-e bizonyos tolerancia feltételeknek:

- $\quad P_{1}^{2}$ értéke nem lehet negatív.

- Megadható, hogy $P_{2}^{2}$ legfeljebb hányszorosa lehet $P_{1}^{2}$-nek. Ezzel a nem mozgó elemek jól szürhetőek.

- Megadható, hogy legalább és legfeljebb mekkora értéket vehet fel $P_{1}{ }^{2}$ és $P_{2}^{2}$. Ezzel szintén a nem mozgó elemek szürhetőek.

- Megadható, hogy hány szomszédos pixel $K^{2}$ értékét átlagolja a program. Ezzel némiképp csökkenthető a zaj mértéke.

- Megadható, hogy az illesztett görbe legfeljebb mekkora része lehet a negatív tartományban.

Az utolsó pont egy elvileg nem megengedhető feltételt tartalmaz. A kontraszt (32) definíciója és a (74) formula alapján ugyanis az egyes expozíciós időkhöz tartozó $K^{2}$ értékek egyike sem, valamint az illesztett görbe egyetlen pontja sem vehet fel 0-nál kisebb 
értéket. A feltételre mégis szükség van, mivel egyetlen pixel esetén a különböző expozíciós időknél meghatározott kontrasztértékek jelentős véletlenszerü, független zajjal terheltek. Tovább rontott a helyzeten az, hogy a RAM véges mérete, illetve a véges memóriasávszélesség miatt csupán 11 értékre lehetett kerekíteni a $K^{2}$ értékeket. Úgy tapasztaltam, hogy mindezek eredményeként az illesztett görbének akár a 20\%-a is a negatív tartományban lehet.

\subsection{Kiértékelés}

A képrögzítő programmal párhuzamosan egy kontrasztérték-számító program fejlesztése is folyt. Kezdetben ezt a munkát is témavezetőm végezte, majd fokozatosan átvettem tőle a feladatot. A program beolvasta a kiválasztott fájlokat, majd a 3 kijelölt terület kontrasztértékeit expozíciós idő szerint csoportosítva vagy átlagolva elmentette egyegy fájlba. A kiértékelést ezután Origin 7.0 segítségével kellett elvégezni függvényillesztéssel. 2010 során a programon végrehajtott első komoly fejlesztés annak áttekinthetővé tételét célozta meg. Ezt néhány funkcionális bővítés (3 helyett 4 kijelölhető terület, opcionális mentés, kiértékelési sebesség növelése) követte. A közel valós időben történő több expozíciós időt felhasználó mérések azonban merőben új kiértékelési módszert követeltek meg, amelynek bevezetése rendkívül nehézkes lett volna, így alapjaitól kezdve egy új kiértékelő program fejlesztésébe kezdtem 2011-ben.

Bár a méréseket végző program képes volt információt nyújtani a mintában lévő szóró elemek mozgásáról, azonban az erőforrások korlátossága miatt ez nem minden esetben volt elegendő. A kiértékelő program - a valós időben történő kiértékeléssel járó szigorú időkorlátok nélkül - jóval részletgazdagabb képet tudott adni a vizsgált terület viselkedéséről a mérések során. A program elvárt funkciói a következők voltak:

- Négy kijelölhető terület, ezek sebességinformációinak megjelenítése, valamint a különféle paraméterek (sebesség-, kontraszt-, illesztési paraméter információk) opcionális elmentése

- Egyetlen expozíciós idő alkalmazásával rögzített képsorozat kiértékelése

- Hagyományos vagy kapcsolóüzemü, több expozíciós idő alkalmazásával rögzített képsorozat kiértékelése

- Közel valós idejü több expozíciós időt felhasználó képsorozat kiértékelése

A fejlesztés során felhasználhattam a képrögzítő program egyes elemeit, ami nagymértékben megkönnyítette a munkámat. Mivel egyes funkciókat elhagyhattam (pl. 
puffer mủveletek, expozíció vezérlése, stb.), így a program szerkezete is jóval egyszerübbé vált, mint a méréseket végző program esetén. A fejlesztés eredményeként már nem volt szükség a kiértékeléshez Origin használatára, azt csupán az eredmények ábrázolásához kellett alkalmazni. 


\section{0. Összefoglalás}

Az orvostudományban a lézeres szórási interferencia egyik alkalmazási területe a lézeres szórási interferencia kontrasztelemzésen alapuló véráramlásmérés („Laser Speckle Contrast Analysis", LASCA), melynek során a vizsgált agyfelszíni vagy szemfenéki szövetet lézerfénnyel világítják meg. Ezen szövettípusok esetén a fény föként a vörösvértestekről szóródik, amit a területet figyelö kamera fényérzékeny chipjére képeznek le. A keletkező szórási interferenciakép egyik objektív mérőszáma a kontraszt, ami a kép valamely területén található pixelek értékei szórásának és átlagának a hányadosa: $K=\sigma /\langle I\rangle$. Ezt jellemzően a kép $5 \times 5$ pixelnyi szegmensein határozzák meg (lokális kontraszt), így előállítható a vizsgált terület kontraszttérképe. A továbbiakban a kontraszt kifejezéssel a kontraszttérkép valamely nagyobb (pl. egy érnek megfelelő) területén meghatározott lokális kontrasztértékek átlagára fogok utalni. Ha a megvilágított minta mozog vagy mozgó szóró elemeket tartalmaz (pl. az áramló vörösvértestek az élő szövetek esetén), a szórási interferenciakép is időben változik. Ez a kamerával rögzített kép elmosódásához és a kontraszt csökkenéséhez vezet. Egy ilyen minta esetén a kontraszt értéke szigorúan monoton csökken az expozíciós idő $(T)$ függvényében, és határértékei $\lim _{T \rightarrow 0} K(T)=\beta \leq 1$ és $\lim _{T \rightarrow \infty} K(T)=0$, ahol $\beta$ az adott mintát és a megvilágító illetve leképező rendszert együttesen jellemző korrekciós tényező. Ezek ismeretében a kontraszt értéke alapján egy megfelelő összefüggés segítségével megállapítható a fényérzékeny chip egyes pixelei által mutatott intenzitásértékek időbeli változását jellemző autokorrelációs idő (röviden korrelációs idő, $\tau$ ) értéke, ami fordítottan arányos a mintában mozgó elemek karakterisztikus sebességével. A képkiértékelési eljárások eleinte inkább csak kvalitatívan jellemezték a véráramlásban, perfúzióban bekövetkező esetleges változásokat. Bőrszövet esetén ez különösen igaz volt, mivel a mozdulatlan szövetrészek okozta statikus szóródás egy additív taggal terhelte a kontraszt négyzetét, azaz $\lim _{T \rightarrow \infty} K(T)>0$. Mivel ennek meghatározása egyetlen expozíciós idő alkalmazása esetén nem lehetséges, így a jelenleg alkalmazott, egyetlen expozíciós időt felhasználó módszerek nem teszik lehetővé a különböző személyeken, vagy egy személyen, de különböző körülmények között elvégzett mérések eredményeinek megbízható összehasonlítását.

Célom a kutatás során egy olyan módszer kidolgozása és mérőrendszer megépítése volt, ami alkalmas bármilyen szövettípus monitorozására azáltal, hogy automatikusan 
alkalmazkodik annak szórási tulajdonságaihoz. A munkám során elért eredményeimet a következő tézispontokban foglaltam össze.

A vizsgált mintában lévő mozdulatlan szóró elemek (pl. latex szuszpenziót elfedő Teflon fólia) a kontraszt négyzetének eltolódását okozhatja, ami akár lehetetlenné is teheti az áramlási vagy perfúziós értékek meghatározását. Sajnos az eltolódás mértéke nem határozható meg egyetlen expozíciós idő alkalmazása esetén. Több expozíciós idő alkalmazásával lehetőség nyílik arra, hogy a kontrasztérték változását ne az elrendezésre és a mintára jellemző előre definiált $\lim _{T \rightarrow 0} K(T)=\beta \leq 1$ értékhez képest vizsgáljuk meg, hanem az egyes expozíciós időknél meghatározott kontrasztértékeket egymással hasonlítsuk össze. A mérések során latex mikrogömb szuszpenziót helyeztem el egy küvettában, melyet 50 illetve $100 \mu \mathrm{m}$ vastag Teflon fóliával, valamint pauszpapírral takartam le. A minta segítségével olyan szövetet imitáltam, ami nem mozgó szóró elemeket is tartalmaz.

1. Kidolgoztam egy módosított expozíciós idő - kontraszt összefüggést, melynek segítségével a különböző expozíciós időknél meghatározott kontrasztértékekre történő függvényillesztéssel feltérképezhetőek a vizsgált minta szórási tulajdonságai és egyúttal lehetőség nyílik az áramlásra jellemző valós korrelációs idő meghatározására. A kiértékelés során a $\lim _{T \rightarrow 0} K(T)$ és $\lim _{T \rightarrow \infty} K(T)$ aszimptotikus kontrasztértékekből származtatott két, a minta szórási tulajdonságait és a megvilágító illetve leképező rendszert együttesen jellemző illesztési paramétert alkalmaztam. Az általam kidolgozott módszer esetén az eredményeket nem, vagy csak csekély mértékben befolyásolta a vizsgált minta esetleges statikus szórása [51].

Megvizsgáltam az általam kidolgozott, több expozíciós idő felhasználásán alapuló módszer alkalmazhatóságát és szükségességét agyfelszíni mérések során, és a kapott eredményeket összevetettem azokkal, amelyek egyetlen expozíciós idő alkalmazása esetén adódnak.

2. Agyfelszíni mérések során megmutattam, hogy a nyugvó szóró elemeket nem tartalmazó szövetek esetén elegendő lehet a $\beta=\lim _{T \rightarrow 0} K(T)$ korrekciós faktor és egyetlen expozíciós idő alkalmazása, azonban az optimális eredmény érdekében az 
expozíciós időt úgy kell megválasztani, hogy az az expozíciós idő - kontraszt görbe inflexiós pontjának közelében legyen; ez az említett szövettípus esetén 1-5 ms. Ellenkező esetben a mért áramlási értékeket meghamisíthatja a kontrasztértékek telítődése [57].

Megvizsgáltam az általam kidolgozott, több expozíciós idő felhasználásán alapuló módszer alkalmazhatóságát a bőrszövet vérellátásában bekövetkező változások (a kar elszorítása majd felengedése) követésére. Az eredményeket összehasonlítottam egyetlen expozíciós idő alkalmazásával kapott értékekkel. Nyolc jelentkezőn összesen 20 méréssorozatot végeztem. A mérésekkel egy időben egy, a mindennapi orvosi gyakorlatban is használt Doppler-rendszerrel referenciaméréseket végeztem, az általa mutatott értéket hitelesnek tekintettem, a különféle LASCA módszerek eredményeit ezekhez viszonyítottam.

3. Megmutattam, hogy az alkar bőrszövetének vérellátásában bekövetkező változások vizsgálata során az általam kidolgozott, több expozíciós időt alkalmazó módszer lényegesen pontosabb eredményt nyújthat bőrszövet esetén, mint az egy expozíciós időt alkalmazó ( $\beta=\lim _{T \rightarrow 0} K(T)$ korrekciós faktort felhasználó és nem felhasználó) módszerek [59].

4. Alkar bőrszövetének vérellátásában bekövetkező változások vizsgálata során megmutattam, hogy a bőrszövet szórási tulajdonságai és ezzel együtt az áramlási érték meghatározásánál alkalmazott $\lim _{T \rightarrow 0} K(T)$ és $\lim _{T \rightarrow \infty} K(T)$ értékek számottevően eltolódhatnak a vérellátottságban bekövetkező jeletősebb változások esetén. Ez hamis eredményekhez vezethet az egy expozíciós időt alkalmazó módszerek esetén, míg több expozíciós idő alkalmazásával a változások nyomon követhetőek [59].

Az általam eredetileg kidolgozott, több expozíciós időt alkalmazó módszer legfőbb hátránya a valós idejű mérésekhez közel sem elegendő időbeli felbontás: egyetlen mérés során több expozíciós időt alkalmazva, mindegyikkel legalább 5 kép rögzítése szükséges a kontrasztértékeket terhelő zaj miatt. Ezen tovább rontott a rendszerben addig alkalmazott, viszonylag lassan mozgatató változtatható abszorbanciájú neutrális szürő. Első lépésként 
egy olyan költséghatékony megoldást kerestem, melynek segítségével az expozíciós idő képkockáról képkockára néhány ezredmásodperc alatt szabadon állítható.

5. Kimutattam, hogy a lézerdióda áramának megfelelő kapcsolóüzemú vezérlésével gyors, megbízható és rendkívül költséghatékony módon megvalósítható a lézedióda átlagintenzitásának változtatására stabil, módusugrásoktól mentes üzemeltetés mellett. Az egyes expozíciók azonos számú és azonos tulajdonságú felvillanásokból állnak, és az expozíciós időt a felvillanások között eltelt idő hangolásával lehet változtatni képkockáról képkockára. Így a kamera integrációs idejét állandó értéken lehet tartani, ami csökkenti a kamera nemlineáris tulajdonságai által okozott torzulásokat [60].

A fejlesztés következő lépéseként kidolgoztam egy olyan eljárást, melynek segítségével több expozíciós idő alkalmazása mellett is közel valós idejű méréseket lehet elvégezni.

6. Kidolgoztam egy mintavételezési és kiértékelési eljárást, ami - az illesztési paraméterek inicializálását követően - lehetővé teszi, hogy a mérőrendszer minden második rögzített képkockát követően megmutassa a vizsgált terület áramlástérképét, miközben a szórási tulajdonságok változása esetén folyamatosan képes újrahangolni az illesztési paramétereket. Ez az eljárás kombinálja az egy expozíciós időt alkalmazó módszerek nagy sebességét és kis reakcióidejét az általam kifejlesztett több expozíciós időt alkalmazó módszer pontosságával.

Az általam kifejlesztett több expozíciós időt alkalmazó lézeres szórási interferencia kontrasztelemzés, az expozíciós idő szabályozása a lézerdióda áramának kapcsolóüzemü vezérlésével, valamint az általam kifejlesztett mintavételezési és közelítő eljárás segítségével lehetőség nyílt nagyobb területü bőrszövet vérellátásának költséghatékony és megbízható mérésére. Egy, a felsorolt módszereken alapuló eszköz különösen hasznos lehet égési sérülések, transzplantált szövetek, cukorbetegség szövődményeinek vagy rákos elváltozások vizsgálata során. 


\section{Summary}

When coherent light falls on an optically rough surface, and the scattering radiation is caught by a canvas, speckle pattern is formed on it. The phenomenon is used in industrial, medical, etc. applications. However one can find the phenomenon in such common devices as the laser optical mouse.

One of the medical applications is the measurement of the blood flow or blood perfusion based on the laser speckle contrast analysis (LASCA). With this technique, the cerebral or ocular tissue is illuminated by laser light, which is primarily scattered by the red blood cells and is imaged by a camera. One of the objective properties of the speckle image is its contrast, which is defined by the ratio of the intensity values of the pixels on a selected segment of the image: $K=\sigma /\langle I\rangle$. The contrast is generally calculated over $5 \times 5$ pixel segments of the image (i. e. local contrast), and, as a result, the contrast map of the examined area can be determined. In the following part of the summary the average of the local contrast values over a selected area (e. g. the area corresponding to a vessel) will be referred as contrast. If the illuminated sample moves or contains moving scattering parts (e. g. red blood cells), the speckle pattern changes in time which results in the blurring of the time-integrated image. In the case of such a sample, the contrast is strictly monotonically decreasing as a function of the exposure time $(T)$, and its boundaries are $\lim _{T \rightarrow 0} K(T)=\beta \leq 1$ and $\lim _{T \rightarrow \infty} K(T)=0$, where $\beta$ is a correction factor related to the illumination and the imaging system. By the use of these asymptotic values and the actual contrast value, one can determine the autocorrelation time (shortly: correlation time, $\tau$ ) related to the changes of the intensity values shown by the pixels of the imaging chip which is supposed to be inversely proportional to the characteristic speed of the moving scatterers. The first applications were able to characterize these changes qualitatively, especially in the case of skin, since the static parts of the sample (i. e. the skin surface) add an offset to the square of the contrast, $\lim _{T \rightarrow \infty} K(T)>0$. As the amplitude of this offset cannot be determined by the use of one exposure time, the results of measurements performed on different persons or under different circumstances cannot be compared to each other reliably. 


\section{Scientific results}

When the flow or perfusion rate is evaluated by the use of one exposure time, the contrast value is compared to the pre-determined $\lim _{T \rightarrow 0} K(T)=\beta \leq 1$ value. Unfortunately, the static scattering parts of the examined sample can give an offset to the square of the offset. Since the amplitude of this offset cannot be determined by the use of one exposure time, it can prohibit the determination of the intensity of the perfusion or the flow. When several exposure times are applied, the contrast values determined at each exposure time can be compared to each other instead of a pre-determined value. I performed the measurements on latex microsphere suspension filled in a cuvette which was covered by 50 and $100 \mu \mathrm{m}$ thick Teflon foil and tracing paper. This sample provided similar scattering properties to those of living tissues containing non-moving parts.

1. I elaborated a modified expression to describe the dependence of the contrast on the exposure time. The use of this makes one able to determine the scattering properties of the sample and the real correlation time by fitting a curve on the contrast values measured at different exposure times. I used the $\lim _{T \rightarrow 0} K(T)$ and the $\lim K(T)$ asymptotic contrast values as fitting parameters which characterize the scattering properties of the sample and the properties of the illumination and the imaging system. The results provided by this method are only a little bit or not affected by the static scattering of the sample [53].

I examined the applicability and necessity of the application of multiple exposure times during the measurement of cerebral blood perfusion and flow rate. I compared the results to the results evaluated by the use of one exposure time.

2. I showed that during the evaluation of blood perfusion and flow rate of tissues which do not contain static scattering parts, the use of one exposure time and the $\beta=\lim _{T \rightarrow 0} K(T)$ correction factor should provide adequate results. However, to achieve the optimal result, the exposure time should be near to the inflexion point of the exposure time - contrast curve which can be found generally between 1 and $5 \mathrm{~ms}$ for 
the mentioned type of tissue. The use of longer or shorter exposure time may detrimentally affect the results as the contrast values may show saturation [57].

I examined the applicability of the multi-exposure LASCA method for the evaluation of the changes (post occlusive reactive hyperaemia) of the skin perfusion. I evaluated the results to them of two singe-exposure methods. I performed 20 measurements on the forearm of 8 volunteers. Simultaneously, I monitored the perfusion rate by the use of a Doppler system which is used in the daily medical routine. I compared the results of the LASCA methods to the results of the latter system as I them as standard reference values.

3. I showed that the multi-exposure LASCA method elaborated by me can provide more accurate information regarding to the changes of the blood perfusion rate of the skin of the forearm than the LASCA methods utilizing only one exposure time combined or not combined with the $\beta=\lim _{T \rightarrow 0} K(T)$ correction factor [59].

4. I showed that the scattering properties of the skin as well as the $\lim _{T \rightarrow 0} K(T)$ and $\lim _{T \rightarrow \infty} K(T)$ values might change considerably if the perfusion rate of the tissue varies significantly. This may lead to false results if only one exposure time is applied, however, the changes can be followed by the use of multiple exposure times [59].

A considerable drawback of the original LASCA method I developed utilizing multiple exposure times is the low temporal resolution which is insufficient for the real-time measurements, since at least 5 images have to be recorded for each exposure time to reduce the statistical noise. The variable neutral density filter which needed relatively long time to be positioned further reduced the temporal resolution. To resolve the problem, I looked for a cost-effective method to change the exposure time from frame to frame within a few milliseconds.

5. I showed that the switching mode control of the current of the laser diode was a fast, reliable and cost-effective method for the control of the exposure time providing mode hop-free illumination and constant light intensity. Each exposure consisted of the same number of similar flashes, and the exposure time could be controlled by the 
separation time between the flashes from frame to frame. The integration time of the camera could be constant which decreased the effects caused by the nonlinearity of the camera [60].

The next step of the development was the introduction of a technique which is able to provide near-to real-time measurements even by the use of multiple exposure times.

6. I elaborated a sampling and analysing process which - next to the initialization of the fitting parameters - provides the full-field perfusion map of the sample following every second frames, while it is able to re-tune itself continuously according to the changes of the scattering properties of the sample. This method combined the high speed and short reaction time with the single-exposure methods with the high accuracy of the multi-exposure one developed by me.

I combined the laser speckle contrast analysis based on the use of multiple exposure times with the adjustment of the exposure time by the switching mode control of the driving current of the laser diode and a sampling and approximation method. This technique provides the cost-effective and reliable monitoring of the skin perfusion over large areas simultaneously. A medical device based on the methods described above could be extremely useful in the case of the examination of burn injuries, transplanted tissues, diabetic dermadromes, or cancerous mutations. 


\section{Köszönetnyilvánítás}

Ezúton szeretném megköszönni témavezetőmnek, Dr. Smausz Kolumbán Tominak segítségét és támogatását munkám során. Köszönöm, hogy bármikor fordulhattam hozzá tanácsért ahogy hallgatóként, úgy doktoranduszként is. Köszönöm, hogy a kutatást mindig az elöre haladás irányába terelte.

Köszönöm továbbá Dr. Hopp Bélának, a Fény-anyag Kölcsönhatás Laboratórium vezetőjének, hogy munkám során támogatott, minden eszközt biztosított a fejlesztésekhez és minden akadályt elhárított a kutatás elöl. Köszönöm a Fény-anyag Kölcsönhatás Laboratórium minden munkatársának a kutatás során nyújtott támogatást.

Köszönettel tartozom Bari Ferenc professzor úrnak azért, hogy rámutatott a kutatási területre, és tanácsaira alapozva megkezdhettük a kutatást. Köszönettel tartozom a disszertációm áttekintése során nyújtott hasznos tanácsaiért is.

Szeretném megköszönni a Szegedi Tudományegyetem Élettani Intézet Cerebrovaszkuláris Laboratórium munkatársainak, Dr. Domoki Ferencnek, Tóth-Szűki Valériának és Dr. Oláh Orsolyának az együttműködés lehetőségét, valamint a szoftverfejlesztés során nyújtott nélkülözhetetlen és pótolhatatlan segítséget illetve türelmet.

Köszönettel tartozom továbbá Barna Angélának, Hanyecz Veronikának, Jójárt Péternek, Kiss Bálintnak, Dr. Makra Péternek és Tátrai Dávidnak a dolgozatom áttekintése során nyújtott segítségért.

Köszönöm feleségemnek, hogy sosem hagyott csüggedni és tanácsaival, támogatásával minden akadályon segített felülkerekedni. Köszönöm családomnak a támogatást és a bíztatást.

Végül, de nem utolsó sorban köszönetemet fejezem ki az egyetem mindazon dolgozóinak, akik valamilyen módon segítették eddigi munkámat.

A dolgozatban közzétett kutatások anyagi hátterét az OTKA F67816, az OTKA K100851, „Az SZTE Kutatóegyetemi Kiválósági Központ tudásbázisának kiszélesítése és hosszú távú szakmai fenntarthatóságának megalapozása a kiváló tudományos utánpótlás biztosításával” (TÁMOP-4.2.2/B-10/1-2010-0012), az „Impulzuslézerek alkalmazása az anyagtudományban és a biofotonikában” (TÁMOP-4.2.2.A-11/1/KONV-2012-0060), valamint a „Környezeti tényezők és genetikai faktorok interakciójának vizsgálata 
immunmediált és daganatos betegségek kialakulásában" (TÁMOP-4.2.2.A-11/1/KONV2012-0035) források biztosították. 


\section{Referenciák}

[1] A. Ishimaru: Wave propagation and scattering in random media, ISBN 0-7803-4717$X$, IEEE Press and Oxford University Press (1999)

[2] J. Q. Lu, P. Yang, and X. Hu: Simulations of light scattering from a biconcave red blood cell using the finite-difference time-domain method, J. Biomed. Opt. 10(2), $024022(2005)$

[3] J. He, A. Karlsson, J. Swartling, and S. Andersson-Engels: Light scattering by multiple red blood cells, CODEN:LUTEDX/(TEAT-7117)/1-16/(2003), (2003)

[4] T. I. Zohdi and F. A. Kuypers: Modelling and rapid simulation of multiple red blood cell light scattering, J. R. Soc. Interface 3, 823-831 (2006)

[5] J. Lim, H. Ding, M. Mir, R. Zhu, K. Tangella, and P. Popescu: Born approximation model for light scattering by red blood cells, Biomed. Opt. Express 2(10), 2784-2791 (2011)

[6] K. Nagayama and K. Honda: 3D Particle Simulations of Deformation of Red Blood Cells in Micro-Capillary Vessel. Fluid Dynamics, Computational Modeling and Applications, ISBN 978-953-51-0052-2, InTech (2012)

[7] V. V. Tuchin: Handbook of optical biomedical diagnostics, ISBN 0-8194-4238-0, SPIE Press (2002)

[8] Y. Park, M. Diez-Silva,G. Popescu, G. Lykotrafitis, W. Choi,M. S. Feld, and S. Suresh: Refractive index maps and membrane dynamics of human red blood cells parasitized by Plasmodium falciparum, PNAS 105(37), 13730-13735 (2008)

[9] Budó Ágoston - Mátrai Tibor: Kísérleti fizika III., Tankönyvkiadó, Budapest (1977)

[10] V. V. Barun, A. P. Ivanov, A. V. Volotovskaya, and V. S. Ulashchik: Absorption Spectra and Light Penetration Depth of Normal and Pathologically Altered Human Skin, J. Appl. Spectrosc. 74(3), 430-439 (2007)

[11] R. Jones \& C. Wykes: Holographic and speckle Interferometry, Second Edition, ISBN 0-521-34878-1, Cambridge University Press (1989)

[12] B. Ruth: Velocity measurement by the laser speckle method using optical fibres, Opt. Laser Technol. 19(2), 83-90 (1987)

[13] K. Iwata, T. Hakoshima, and R. Nagata: Measurement of flow velocity distribution by multiple-exposure speckle photography, Opt. Commun. 25(3), 311-314 (1978) 
[14] M. Giglio, S. Musazzi, and U. Perini: Distance measurement from a moving object based on speckle velocity detection, Appl. Opt. 20(5), 721-722 (1981)

[15] D. V. Semenov, I. S. Sidorov, E. Nippolainen, and A. A. Kamshilin: Speckle-based sensor system for real-time distance and thickness monitoring of fast moving objects, Meas. Sci. Technol. 21(4), (2010)

[16] M. Shiraishi and K. Sato: Possibility of Large Roughness Measurement by Laser Speckle, Transactions of the ASME 113, 476 (1991)

[17] D. Léger, E. Mathieu, and J. C. Perrin: Optical Surface Roughness Determination Using Speckle Correlation Technique, Appl. Opt. 14(4), 872-877 (1975)

[18] J. Marron, A. J. Martino, and G. M. Morris: Generation of random arrays using clipped laser speckle, Appl. Opt. 25(1), 26-30 (1986)

[19] P. Lalanne, H. Richard, J.C. Rodier, P. Chavel, J. Taboury, K. Madani, P. Garda, and F. Devos: 2-D generation of random numbers by multimode fiber speckle for silicon arrays of processing elements, Opt. Commun. 76(5-6), 387-394 (1990)

[20] J. W. Goodman: Statistical Properties of Laser Speckle Patterns. Laser Speckle and Related Phenomena, ISBN 3-540-07498-8, Springer-Verlag (1975)

[21] A. F. Fercher and J. D. Briers: Flow visualization by means of single-exposure speckle photography, Opt. Commun. 37(5), 326-330 (1981)

[22] H. Z. Cummins, E. R. Pike: Photon correlation and light beating spectroscopy, Plenum Press (1974)

[23] A. K. Javanthy, N. Sujatha, and M. Ramasubba Reddy: Measuring blood flow: Techniques and applications - a review, IJRRAS 6(2), 203-216 (2011)

[24] A. B. Parthasarathy, W. G. Shin, X. J. Zhang, A. K. Dunn: Laser Speckle Contrast Imaging of flow in a microfluidic device, Biomedical Applications of Light Scattering, ISBN 9780071598811, McGraw Hill Professional (2009)

[25] J. D. Briers, S. Webster: Quasi real-time digital version of single-exposure speckle photography for full-field monitoring of velocity or flow fields, Opt. Commun. 116, 36-42 (1995)

[26] S. J. Kirkpatrick, D. D. Duncan, and E. M. Wells-Gray: Detrimental effects of speckle-pixel size matching in laser speckle contrast imaging, Opt. Lett. 33(24), 2886-2888 (2008)

[27] O. P. Thompson, M. Andrews, and E. Hirst: Correction for spatial averaging in laser speckle contrast analysis, Biomed. Opt. Express 2(4), 1021-1029 (2011) 
[28] J. D. Briers and S. Webster: Laser speckle contrast analysis (LASCA): a nonscanning, full-field technique for monitoring capillary blood flow, J. Biomed. Opt. 1(2), 174-179 (1996)

[29] H. Cheng, Q. Luo, S. Zheng, S. Chen, J. Cen, and H. Gong: Modified laser speckle imaging method with improved spatial resolution, J. Biomed. Opt. 8(3), 559-564 (2003)

[30] A. C. Völker, P. Zakharov, B. Weber, A. Buck, and F. Scheffold: Laser speckle imaging with an active noise reduction scheme, Opt. Express 13(24), 9782-9787 (2005)

[31] N. Konishi, Y. Tokimoto, K. Kohra, and H. Fuji: New Laser Speckle FIowgraphy System Using CCD Camera, Opt. Rev. 9(4), 163-169 (2002)

[32] J. Qui, P. Li, W. Luo, J. Wang, H. Zhang, and Q. Luo: Spatiotemporal laser speckle contrast analysis for blood flow imaging with maximized speckle contrast, J. Biomed. Opt. 15(1), 016003 (2010)

[33] A. Kuramoto, A. Hori, and I. Fujieda: Laser Speckle Imaging of a Finger by Scattered Light Optics, PIERS Online 3(6), 832-835 (2007)

[34] Y. Tamaki, M. Araie, E. Kawamoto, S. Eguchio, and H. Fujii: Noncontact, TwoDimensional Measurement of Retinal Microcirculation Using Laser Speckle Phenomenon, Invest. Ophth. Vis. Sci. 35(11), 3825-3834 (1994)

[35] M. Nagahara, Y. Tamaki, A. Tomidokoro, and M. Araie: In Vivo Measurement of Blood Velocity in Human Major Retinal Vessels Using the Laser Speckle Method, Inverst. Ophth. Vis. Sci. 52(1), 87-92 (2011)

[36] R. Bandyopadhyay, A. S. Gittings, S. S. Suh, P. K. Dixon, and D. J. Durian: Specklevisibility spectroscopy: a tool to study time-varying dynamics, Rev. Sci. Instrum. 76, $093110(2005)$

[37] P. A. Lemieux and D. J. Durian: Investigating non-Gaussian scattering processes by using $n$ th-order intensity correlation functions, JOSA A 16(7), 1651-1664 (1999)

[38] A. K. Dunn, A. Devor, H. Bolay, M. L. Andermann, M. A. Moskowitz, A. M. Dale, and D. A. Boas: Simultaneous imaging of total cerebral hemoglobin concentration, oxygenation, and blood flow during functional activation, Opt. Lett. 28(1), 28- 30 (2003)

[39] Kharlamov, B. R. Brown, K. A. Easley, and S. C. Jones: Heterogeneous response of cerebral blood flow to hypotension demonstrated by laser speckle imaging flowmetry in rats, Neurosci. Lett. Suppl. 368(2), 151-156 (2004) 
[40] J. D. Briers and A. D. Fercher: Retinal blood-flow visualization by means of laser speckle photography, Invest. Ophthamol. Vis. Sci. 22(2), 255-259 (1982)

[41] Y. Aizu, K. Ogino, T. Sugita, T. Yamamoto, N. Takai, and T. Asakura: Evaluation of blood flow at ocular fundus by using laser speckle, Appl. Opt. 31(16), 3020-3029 (1992)

[42] M. Nagahara, Y. Tamaki, M. Araie, and H. Fujii: Real-time blood velocity measurements in human retinal vein using the laser speckle phenomenon, Jpn. J. Ophthalmol. 43(3), 186-195 (1999)

[43] J. C. Ramirez-San-Juan, R. Ramos-Garcia, I. Guizar-Iturbide, G. Martinez-Niconoff, and B. Choi: Impact of velocity distribution assumption on simplified laser speckle imaging equation, Opt. Express 16(5), 3197-3203 (2008)

[44] J. D. Briers: Laser Doppler, speckle and related techniques for blood perfusion mapping and imaging, Physiol. Meas. 22(4), (2001)

[45] P. Zakharov, A. Völker, A. Buck, B.Weber, and F. Scheffold: Quantitative modeling of laser speckle imaging, Opt.Lett. 31(23), 3465-3467 (2006)

[46] K. R. Forrester, I. C. Stewart, I. J. Tulip, C. Leonard, and R. C. Bray: Comparison of laser speckle and laser Doppler perfusion imaging: measurement in human skin and rabbit articular tissue, Med. Biol. Eng. Comput., 40(6), 687-697 (2002)

[47] J. Stewart, R. Frank, K. R. Forrester, J. Tulip, R. Lindsay, and R. C. Bray: A comparison of two laser-based methods for determination of burn scar perfusion: Laser Doppler versus laser speckle imaging, Burns 31(6), 744-752 (2005)

[48] M. Leutenegger, E. Martin-Williams, P. Harbi, T. Thacher, W. Raffoul, M. André, A. Lopez, P. Lasser, and T. Lasser: Real-time full field laser Doppler imaging, Biomed. Opt. Express 2(6), 1470-1477 (2011)

[49] A. Serov, B. Steinacher, and T. Lasser: Full-field laser Doppler perfusion imaging and monitoring with an intelligent CMOS camera, Opt. Expr. 13(10), 3681-3689 (2005)

[50] O. P. Thompson and M. K. Andrews: Tissue perfusion measurements - multipleexposure laser speckle analysis generates laser Doppler-like spectra, J. Biomed. Opt. 15(2), 027015 (2010)

[51] T. Smausz, D. Zölei, and B. Hopp: Determination of Real Correlation Time and Calibration in Laser Speckle Contrast Analysis, Book of abstracts of 16th Int. Conf. on Advanced Laser Technologies 2008, ISBN 978-963-06-5737-2, LaserSkill Ltd. (2008) 
[52] G. E. Uhlenbeck and L. S. Ornstein: On the Theory of the Brownian Motion, Phys. Rev. 36(5), 823-841 (1930)

[53] T. Smausz, D. Zölei, and B. Hopp: Real correlation time measurement in laser speckle contrast analysis using wide exposure time range images, Appl. Opt. 48(9), 1425-1429 (2009)

[54] Q. Li, B. J. Lee, Z. M. Zhang, D. W. Allen: Light scattering of semitransparent sintered polytetrafluoroethylene films, J. Biomed. opt. 13(5), 054064 (2008)

[55] A. B. Parthasarathy, W. J. Tom, A. Gopal, X. Zhang and A. K. Dunn: Robust flow measurement with multi-exposure speckle imaging, Opt. Express 16(3), 1975-1989 (2008)

[56] D. D. Duncan and S. J. Kirkpatrick: Algorithms for simulation of speckle (laser and otherwise), Proc. of SPIE, 6855, 685505 (2008)

[57] F. Domoki, D. Zölei, O. Oláh, V. Tőth-Szűki, B. Hopp, and T. Smausz: Evaluation of Laser-speckle Contrast Image Analysis Techniques in the Cortical Microcirculation of Piglets, Microvasc. Res. 83(3), 311-317 (2012)

[58] N. C. Abbot, W. R. Ferrell, J. C. Lockhart, J. G. Lowe, Laser Doppler perfusion imaging of skin blood flow using red and near-infrared sources, J. Invest. Dermatol. 107, 882-886 (1996)

[59] D. Zölei, T. Smausz, B. Hopp, F. Bari: Multiple exposure time based laser speckle contrast analysis: demonstration of applicability in skin perfusion measurements, P\&O 1(2), 28-32 (2012)

[60] T. Smausz, D. Zölei, and B. Hopp: Laser power modulation with wavelength stabilization in multiple exposure laser speckle contrast analysis, Proc. of SPIE, 8413, 84131J (2012)

[61] G. Mahé, P. Rousseau, S. Durand, S. Bricq, G. Leftheriotis, and P. Abraham: Laser speckle contrast imaging accurately measures blood flow over moving skin surfaces, Microvasc. Res. 81(2), 183-188 (2011)

[62] C. J. Stewart, R. Frank, K. R. Forrester, J. Tulip, R. Lindsay, and R. C. Bray, A Comparison of Two Laser-based Methods for Determination of Burn Scar Perfusion: Laser Doppler Versus Laser Speckle Imaging, Burns 31(6), 744-752 (2005)

[63] M. Roustit, C. Millet, S. Blaise, B. Dufournet, and J. L. Cracowski, Excellent Reproducibility of Laser Speckle Contrast Imaging to Assess Skin Microvascular Reactivity, Microvasc. Res. 80(3), 505-511 (2010) 